IMOBILIZAÇÃO DAS EXOENZIMAS DE Kluyveromyces marxianus MMII-41 COM ATIVIDADE INULINOLITTICA E PECTINOLITICA

MARCELO FOSSA DA PAZ

Biólogo

Orientador: Prof. Dr. FLAVIO CESAR ALMEIDA TAVARES

Tese apresentada à Escola Superior de Agricultura "Luis de Queiroz", Universidade de São Paulo, para obtenção do título de doutor em Agronomia, Área de Concentração: Microbiologia Agrícola.

PIR A C I C A B A

Estado de São Paulo - Brasil

Fevereiro - 2004 


\section{Dados Internacionais de Catalogação na Publicação (CIP)}

DIVISĀO DE BIBLIOTECA E DOCUMENTAÇÃO - ESALQ/USP

Paz, Marcelo Fossa da

Imobilizaçāo das exoenzimas de Kluyveromyces marxianus MMIII-41 com atividade inulinolítica e pectinolitica / Marcelo Fossa da Paz. - Piracicaba, 2004. 88 p. : il.

Tese (doutorado) - Escola Superior de Agricultura Luiz de Queiroz, 2004. Bibliografia.

1. Enzimas 2. Hidrólise enzimática 3. Inulinase 4. Levedura 5. Pectinase I. Titulo

CDD 574.1925

"Permitida a cópia total ou parcial deste documento, desde que citada a fonte - $\mathrm{O}$ autor" O. doposito junto CPO/ESALC

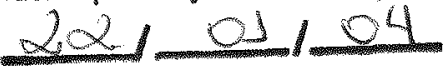


Aos meus pais Antenor e Cleide e aos meus irmãos Dario e Daniel 


\section{AGRADECIMENTOS}

Ao professor Dr. Flavio César Almeida Tavares pela confiança, ensinamentos e orientação.

Ao departamento de Genética da Escola Superior de Agricultura "Luis de Queiroz", pela estrutura e organização.

À CNPq pelo financiamento deste projeto e concessão de bolsa.

Aos colegas do Lab. de Genética de Levedura, Alessandra Rabalho, MS. Alesandro Riffel, Carmo Augusto Lara Poloni, Daniele Toledo Del'Rio, MS. Gildenberg Amorim, Dra. Keila Maria Roncato Duarte, Leandro, Luiz Fernando Romanholo, Mariana, Marcus Venícius de Melo Lourenço, Rodrigo Setem Carvalho, em especial ao Dr. Luiz Humberto Gomes, pelo apoio técnico, convivência e orientações.

Às amigas queridas Ana Maria Brancalion Giacomelli, Alessandra Pupin do Nascimento, Sarah Eliani Carvalho e Giovana Maria de Oliveira por toda força nas horas de desânimo e principalmente pela amizade incondicional.

À Dra. Salete Aparecida Gaziola pela ajuda técnica e pelas idéias e sugestões.

Ao Prof. Decano Dr. Luiz Gonzaga do Prado Filho pelas horas e horas de conversa animada e esclarecedora. 


\section{SUMÁRIO}

Página

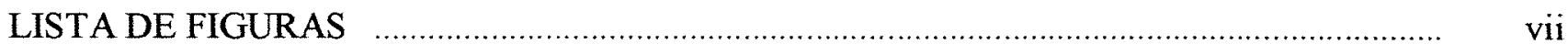

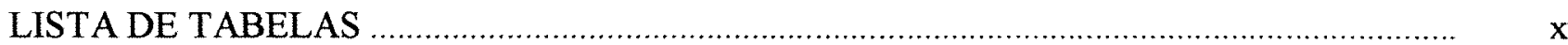

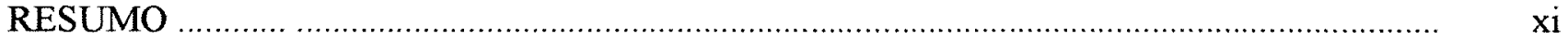

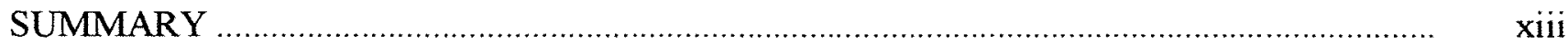

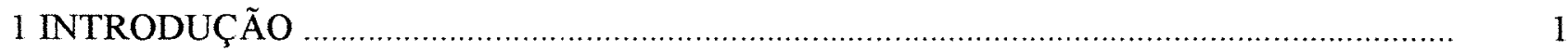

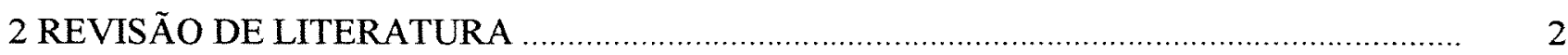

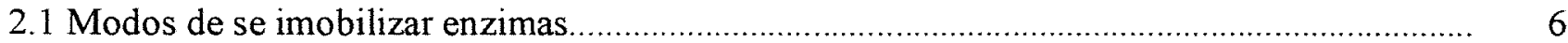

2.2 Tipos de matrizes usadas em Imobilização de enzimas........................................................ 7

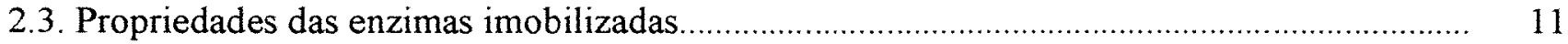

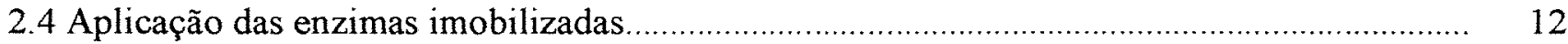

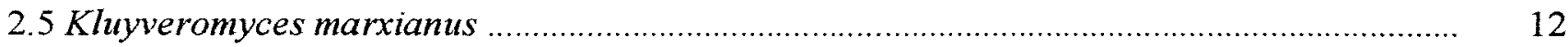

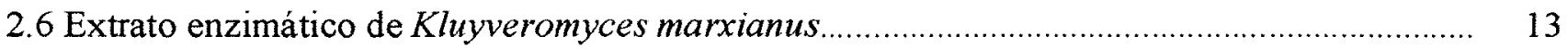

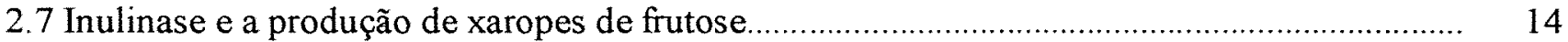

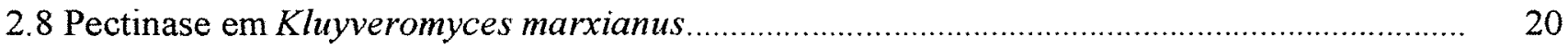

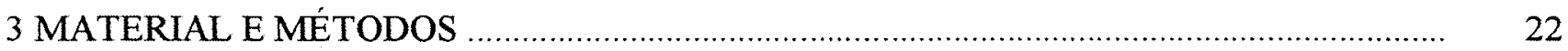

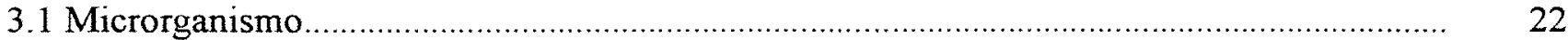

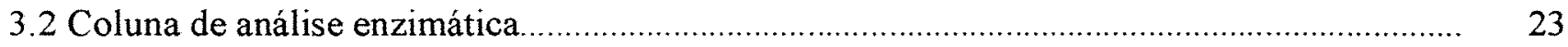

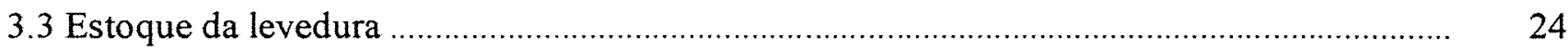

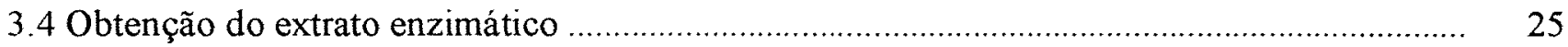

3.5 Pré-Purificação do extrato enzimático por precipitação com sulfato de amônio ..................... 25

3.6 Pré-Purificação do extrato enzimático por precipitação isoelétrica...................................... 26

3.7 Conservação da enzima para os diferentes ensaios................................................. 26

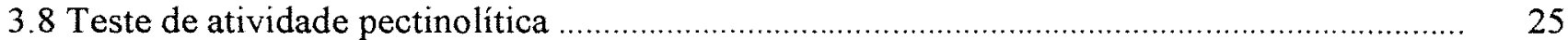


3.9 Ensaios de afinidade enzimática e caracterização

3.10 Imobilização da enzima em alginato de sódio ……........................................................... 28

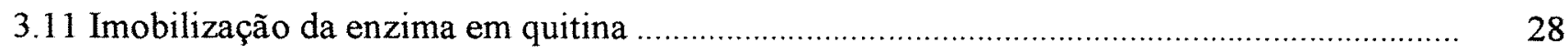

3.12 Imobilização da enzima em poliestireno expandido (isopor) ……………............................... 29

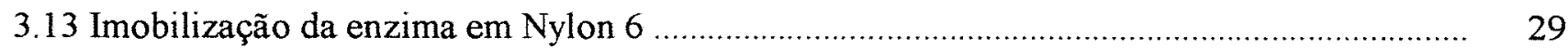

3.14 Imobilização em Copolímero Alginato-quitosana .............................................................. 30

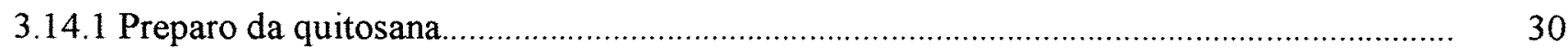

3.14.2 Preparo do copolímero............................................................................................... $\quad 30$

3.14.3 Imobilização da enzima por ligações covalentes ............................................................. 31

3.14.4 Imobilização da enzima por aprisionamento ............................................................... 31

3.15 Ensaio comparativo em sistema batelada ……................................................................ 32

3.16 Determinação da correlação entre as atividades enzimáticas nos diferentes substratos ............. 32

3.17 Ensaio preliminar para a determinação da Vmáx de hidrólise nas diferentes matrizes .............. 33

3.18 Ajustes do processo industrial com a enzima imobilizada ................................................... 34

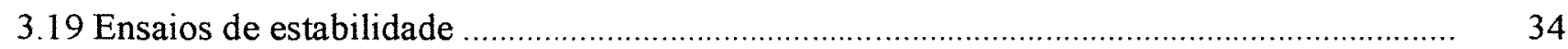

4 RESULTADOS E DISCUSS ÃO …….................................................................................. 35

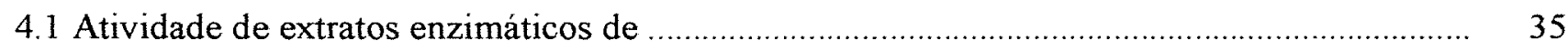

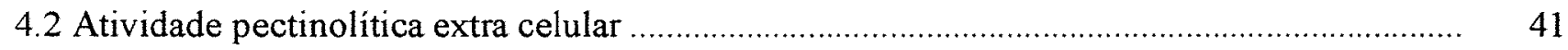

4.3 Purificação das enzimas Precipitação por sulfato de amônio ………....................................... 42

4.4 Atividade enzimática livre e respectiva cinética ....................................................................... 43

4.5 Atividades de invertase e inulinase no sistema descontínuo …...................................... 51

4.6 Atividade de enzimas imobilizadas no sistema contínuo …………......................................... 53

4.7 Experimentos com o Copolímero alginato-gel-quitosana ......................................................... 56

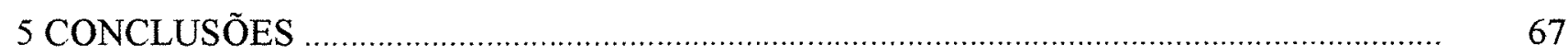

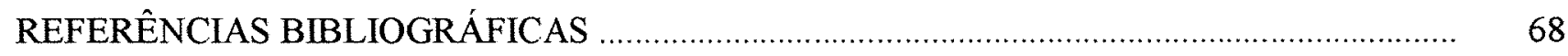

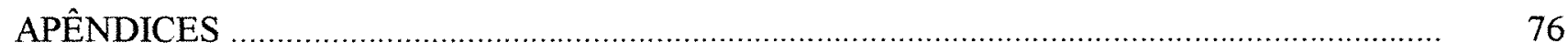




\section{LISTA DE FIGURAS}

Página

1 Estrutura molecular da pectina e sua degradação por pectinase ……....................................... 5

2 Possíveis modos de se imobilizar enzimas ......................................................................... 7

3 Estrutura dos nylons 6 e 6,6, os mais utilizados em processos de imobilização ........................ 9

4 Ligação covalente de enzimas ao nylon envolvendo a da ligação do peptídeo através dos grupos amino primários

5 Estrutura do estireno e seu polímero

6 Estrutura molecular da inulina

7 Aspecto geral da Alcachofra de Jerusalém. Planta florida (A), detalhe da inflorescência (B), tubérculos vermelhos (C) e tubérculos brancos (D)

8 Esquema da obtenção da linhagem Kluyveromyces marxianus MMIII-41 produtora de inulinase tipo A e B

9 Coluna desenvolvida para a análise enzimática

10 Gel de poliacrilamida com SDS corado por "Coomassie Blue" mostrando uma banda de aproximadamente $97 \mathrm{kDa}$ presente no sobrenadante não purificado de Kluyveromyces marxianus MMIII-41

11 Gel de eletroforese não desnaturante corado por "Coomassie Blue" mostrando as duas bandas presentes no sobrenadante não purificado de Kluyveromyces marxianus MMIII-41 ... 37

12 Açúcares formados a partir de substratos ....................................................................... 38

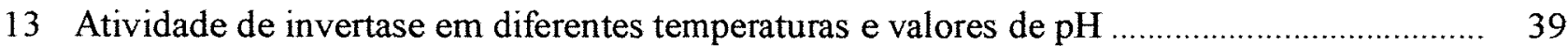

14 Atividade de inulinase em diferentes temperaturas e valores de $\mathrm{pH}$. .................................... 40

15 Atividade de pectinase em diferentes temperaturas e valores de $\mathrm{pH}$.................................... 41

16 Formação de halo aparente pelo $\mathrm{pH}$ de viragem do vermelho gongo decorrente da formação de ácido galacturônico $\mathrm{SC}=$ Saccharomyces cerevisiae Fleischmann; $\mathrm{KM}=$ Kluyveromyces marxianus MMIII-41. 
17 Gráfico demonstrando as quantidades de proteína de cada fração (Barras) e a atividade da enzima nas frações através de quantificação de açúcares redutores formados (linha e losangos)

18 Gráfico de unidades de açúcares redutores formados a partir da pectina, em função do tempo em minutos

19 Gráfico de unidades de açúcares redutores formados a partir da inulina, em função do tempo em minutos

20 Gráfico de unidades de açúcares redutores formados a partir da sacarose, em função do tempo em minutos

21 Gráfico de unidades de sacarose em relação a unidades de pectina geradas na fase exponencial da cinética enzimática, realizada sob mesmas condições. A equação é resultado da regressão linear que permite a conversão de sacarose a pectina

22 Gráfico de unidades de sacarose em relação a unidades de inulina geradas na fase exponencial da cinética enzimática, realizada sob mesmas condições. A equação é resultado da regressão linear que permite a conversão de sacarose a inulina

23 Formação de açúcares redutores (média de três ensaios) por $\mathrm{mL}$ de proteína no decorrer do tempo A curva representada pelos losangos representa a formação de açucares redutores formados à partir da inulina (eixo secundário), a curva representada por triângulos representa a formação de açucares redutores formados à partir da sacarose (eixo primário) e a curva representada por quadrados representa a formação de açucares redutores formados à partir da pectina (eixo primário)

24 Representações gráficas do cálculo de $\mathrm{Km}$ e Vmáx para o substrato inulina gerado pelo programa "Hyperbolic Regression" à partir dos valores obtidos experimentalmente. O gráfico A elaborado pelo método de Michaelis-Menten e o B por Lineweaver-Burk.

25 Representações gráficas do cálculo de $\mathrm{Km}$ e Vmáx para o substrato sacarose gerado pelo programa "Hyperbolic Regression" à partir dos valores obtidos experimentalmente. O gráfico A elaborado pelo método de Michaelis-Menten e o B por Lineweaver-Burk.

26 Imobilização da enzima inulinase nas diferentes matrizes no sistema descontínuo.

27 Comparação de três ensaios realizados em copolímero alginato-quitosana no sistema batelada Os ensaios foram exatamente iguais apenas com o tempo de estocagem da enzima diferente, sendo o primeiro ensaio o representado por losangos, o segundo por quadrados e o terceiro por triângulos.

28 Queda da atividade enzimática no decorrer dos dias nas condições do experimento 
29 Atividade enzimática no copolímero alginato-gel-quitosana em ensaios de fluxo contínuo. A os triângulos representam a concentração de proteínas totais detectada no produto. $\mathrm{O}$ valor representado no tempo zero é a quantidade de proteína do extrato enzimático original. Os losangos representam a atividade enzimática (açúcares redutores $\% \times \min ^{-1} \times 10^{-3}$ ) no decorrer do tempo.

30 Atividade enzimática em função do tempo no ensaio de fluxo contínuo do extrato enzimático imobilizado no copolímero alginato-gel-quitosana frente a sacarose. Os triângulos mostram a atividade do estrato imobilizado enquanto que os quadrados demonstram a atividade da enzima livre (controle).

31 Comparação atividade de inulinase e proteína imobilizada entre as diferentes formas de imobilização no copolímero alginato-gel-quitosana, ligações covalentes e por aprisionamento.

32 Comparação atividade de invertase e proteína imobilizada entre as diferentes formas de imobilização no copolímero alginato-gel-quitosana, ligações covalentes e por aprisionamento.

33 Comparação atividade de pectinase e proteína imobilizada entre as diferentes formas de imobilização no copolímero alginato-gel-quitosana, ligações covalentes e por aprisionamento.

34 Foto demonstrando a diferença de aspecto e diâmetro das esferas do copolímero alginato-gelquitosana imobilizado por aprisionamento (A) e por ligações covalentes (B). 


\section{LISTA DE TABELAS}

Págin

1 Conteúdo de inulina e outros oligofrutanos em alguns alimentos ${ }^{1}$

2 Açúcares redutores formados à partir da sacarose nas diferentes matrizes imobilizadas em sistema batelada. A atividade relativa é a porcentagem de atividade encontrada em relação à atividade do extrato original no mesmo tempo

3 Imobilização nas diferentes matrizes no sistema descontínuo com inulina como substrato. Comparação de atividade e proteínas imobilizadas.

4 Resultados obtidos na imobilização da enzima de $K$. marxianus $\mathrm{MMIII}-41$ em diferentes matrizes. A atividade relativa é a porcentagem de atividade encontrada em relação à atividade do extrato original no mesmo tempo.

5 Resultados médios dos ensaios em sistema descontínuo que determinam as porcentagens de atividade da enzima imobilizada e de proteínas totais em relação ao extrato original e extrato purificado por precipitação com sulfato de amônio

6 Resultados médios dos ensaios em sistema descontínuo na comparação da atividade de inulinase entre as imobilizações por ligações covalentes e por aprisionamento no copolímero alginato-gel-quitosana.

7 Resultados médios dos ensaios em sistema descontínuo na comparação da atividade de inulinase entre as imobilizações por ligações covalentes e por aprisionamento no copolímero alginato-gel-quitosana.

8 Resultados médios dos ensaios em sistema descontínuo na comparação da atividade de inulinase entre as imobilizações por ligações covalentes e por aprisionamento no copolímero alginato-gel-quitosana. 


\title{
IMOBILIZAÇÃO DAS EXOENZIMAS DE KLUYVEROMYCES MARXIANUS MMIII-41 COM ATIVIDADE INULINOLÍTICA E PECTINOLÍTICA
}

\author{
Autor: MARCELO FOSSA DA PAZ \\ Orientador: Prof. Dr. FLAVIO CESAR ALMEIDA TAVARES
}

\section{RESUMO}

A levedura Kluyveromyces marxianus MMIII-41 possui atividade hidrolítica identificada com a produção das enzimas inulinase, invertase e pectinase. A atividade da invertase é mais ativa a temperaturas entre 30 e $40^{\circ} \mathrm{C}$ e pHs entre 4,0 e 6,0 . A atividade da inulinase foi maior em temperaturas mais elevadas não apresentando diferenças significativas entre 40 e $60^{\circ} \mathrm{C}$ e pH em tomo de $5,0.0$ mesmo se observa com a atividade da pectinase não apresentando diferenças significativas 30 a $40^{\circ} \mathrm{C}$ e pHs entre 4,0 e 7,0 . Estas enzimas foram estudadas na condição de imobilização nas matrizes alginato, copolímero alginato-gel-quitosana, nylon $6^{\circledR}$, quitina e isopor, com o objetivo de identificar dentre estas qual seria a mais adequada a estudos futuros de ampliação de escala. As respectivas atividades enzimáticas foram determinadas mediante determinação de açúcares redutores totais formados a partir dos substratos inulina, pectina e sacarose (Somogyi e Nelson, 1945). Os experimentos com as enzimas imobilizadas em cada uma das matrizes foram realizados nos sistemas descontínuo e contínuo. No sistema contínuo ficaram evidentes os problemas operacionais de cada matriz, sendo que o Nylon 6e o isopor não apresentaram atividade já nas primeiras horas de processo. A quitina causou entupimento 
do sistema por compactação e as esferas de alginato em pouco tempo vieram a se desfazer. Nas condições experimentais avaliadas o copolímero alginato-gel-quitosana revelou-se a matriz com maior atividade, estabilidade e vida média. Nesta matriz a melhor atividade da inulinase aconteceu com a imobilização por ligações covalentes, enquanto que a imobilização por aprisionamento produziu melhores resultados para as atividades de pectinase e invertase. 


\title{
KLUYVEROMYCES MARXIANUS MMIII-41 EXONZYME IMMOBILIZATION WITH INULINOLITIC AND PECTINOLITIC ACTIVITIES
}

\author{
Author: MARCELO FOSSA DA PAZ \\ Adviser: Prof. Dr. FLAVIO CESAR ALMEIDA TAVARES
}

\section{SUMMARY}

The Kluyveromyces marxianus MMIII-41 yeast presents hydrolitic activity identifyed with inulinase, invertase and pectinase. The invertase activity is better under temperatures of 30 and $40^{\circ} \mathrm{C}$ and pHs 4,0 and 6,0 . The inulinase activity was better in high temperatures without importamt differences between 40 and $60^{\circ} \mathrm{C}$ and $\mathrm{pH}$ around 5,0 . The same situation is observed with pectinase activity not presenting important differences from 30 to $40^{\circ} \mathrm{C}$ and $\mathrm{pHs}$ between 4,0 and 7,0 . This enzymes were studied in immobilization conditions in alginate, chitosan-alginate-gel copolymer, nylon $6^{\circledR}$, chitin and expanded polystirene, in order to find the best matrice to be used in future studies for the scale amplification. The respective enzymatic activities were measured by reducing sugar methods from inulin, pectin and sucrose on Somogyi and Nelson (1945) method. The experiments with any enzymes were made in bath and continuous system. On continuous systems the operation problems of any matrice become clear. Nylon 6 and expanded polystirene lost activity in the beginning of the process. The chitin obstructed the system by compactation and the alginate beads become deranged in a short time. On the evaluated 
experimental conditions the alginate-chitosan-gel showed the highest activity, stableness and higher mean-life matrice. On this matrice the best inulinase activity was took place by covalent bonds whereas bonding by entrapment was better to pectinase and invertase. 


\section{INTRODUÇÃo}

O desenvolvimento de um processo industrial de hidrólise enzimática só é viável economicamente com o reaproveitamento das enzimas envolvidas neste processo se torna viável através de sua imobilização, o que é feito em diferentes matrizes ou suportes imobilizadores. Dependendo do processo se faz necessário selecionar qual ou quais os suportes mais adequados para a finalidade a que se destinam, sobretudo tendo em conta a ampliação de escala (para tanto se faz necessária a pesquisa de quais matrizes são mais adequadas para este fim).

A levedura Kluyveromyces marxianus MMIII-41 é um híbrido diplóide construído no Laboratório de Genética de Leveduras do Departamento de Genética da ESALQ que possui atividade hidrolítica para inulinase, invertase e pectinase. Esta capacidade hidrolítica ímpar indica potencial utilização desse extrato em sistemas de imobilização enzimática.

Neste trabalho procurou-se estudar as condições de imobilização do sobrenadante de Kluyveromyces marxianus MMIII-41 nas matrizes alginato, no copolímero alginato-gelquitosana, nylon $6^{\circledR}$, quitina e isopor com o objetivo de identificar dentre estes materiais qual seria o mais adequado a ser usado no desenvolvimento de um processo de bancada que possa ser eventualmente utilizado na ampliação de escala. Para tanto foram realizados diversos estudos na tentativa de se avaliar os resultados gerados com as respectivas enzimas em diferentes temperaturas e pHs, durabilidade da atividade e eficiência do processo na escala de bancada. 


\section{2 - REVISÃO DE LITERATURA}

As enzimas são substâncias muito utilizadas na indústria para catalisar reações que geralmente transformam substratos abundantes em produtos de alto valor agregado. Porém, existem alguns problemas operacionais que dificultam sua utilização, como a dificuldade de recuperação das mesmas após o uso e a insolubilidade de alguns substratos em água. Para resolver esses problemas uma possível solução seria a imobilização destas enzimas em suportes (ou matrizes), permitindo que sejam aplicadas em meio orgânico (Queiroz \& Nascimento, 1999).

A condição de reação para cada enzima é específica, identificando-se alguns fatores primordiais que interferem com a atividade enzimática, o que pode acontecer devido a vários fatores, como por exemplo $\mathrm{pH}$ e temperatura. Estes fatores apresentam valores ótimos o que garante alta atividade enzimática obedecendo as respectivas margens de tolerância sem que haja alteração significativa da reatividade. Estes valores podem ser graficamente representados por um padrão de atividade expresso por uma curva de Gauss. Alterações muito bruscas nestes parâmetros podem modificar a configuração espacial da molécula da enzima, tornando-a não ativa, ou inutilizando-a totalmente.

Existem alguns casos relatados na literatura em que a estabilidade da enzima aumenta quando a mesma se encontra ligada ao seu substrato, formando o complexo, enzima-substrato (Kim \& Byun, 1982). 
Outro fator de inutilização das enzimas é a sua degradação causada por outras enzimas do tipo proteases, que tem como função, a quebra de ligações peptídicas. Geralmente os inibidores são moléculas de baixo peso molecular direcionadas ao sítio ativo. Na sua maioria os inibidores irreversíveis são de natureza sintética e os inibidores reversiveis de ocorrência natural. Podem ser usados como inibidores, dentre outros: os fenóis, as lecitinas, e até outras proteínas (García-Carreño, 1996).

Uma maneira eficiente de se reduzir a perda de enzimas em um processo industrial seria a sua imobilização, o que faz com que estas se tornem mais estáveis e tolerantes, ampliando o espectro de atividade dentro do padrão de cada uma das enzimas, o que pode aumentar assim os limites operacionais (Wiseman, 1985).

A imobilização de enzimas se define como o processo pelo qual se restringe total ou parcialmente o seu movimento ou o seu estado disperso em uma massa líquida, obtendo-se uma forma insolúvel ou solúvel de uma enzima, conforme o caso específico (Wiseman, 1985). A imobilização de enzimas, como definido por Trevan (1980) compreende o aprisionamento da molécula de uma enzima em um suporte ou uma fase distinta, porém sem perder a capacidade de troca com a fase onde se encontra o substrato e substâncias inibidoras ou ativadoras, de forma que o substrato possa ser monitorado. Este autor também afirma que o termo imobilização pode causar confusão, por ser associado à ausência de movimento ou fixação. $O$ termo imobilização seria utilizado mais corretamente no caso da insolubilização de enzimas que normalmente são solúveis em água.

Independente da sua definição, a imobilização de células e enzimas é uma alternativa para o desenvolvimento de processos industriais, já que podemos imobilizar praticamente todas as enzimas (Trevisan et al, 2000). Outra vantagem de se imobilizar enzimas é o fato de poderem ser utilizadas em processos contínuos o que é muito importante na manutenção da estabilidade das enzimas pela manutenção de um ambiente constante, diminuição da contaminação por lavagem, bem como, a possibilidade de automação do processo (Martino et al., 1996; Trevisan et al., 2000). Também deve ser considerado como vantagem o fato de enzimas imobilizadas estarem protegidas pelo 
suporte dos efeitos de temperatura, força iônica e alterações bruscas de pH (Wiseman, 1985).

A imobilização de enzimas deve ser realizada em matrizes de baixo custo, cujo processo de imobilização seja seguro, relativamente permanente, versátil e fácil de ser utilizado na ampliação de escala. Tudo isso possibilita uma diminuição no custo de produção de muitos produtos. Para isso, é essencial que sejam estudadas as matrizes já conhecidas e consagradas para outras enzimas, bem como novas alternativas que cumpram as exigências descritas acima (Wiseman, 1985).

A imobilização de enzimas deve ser muito bem estudada para o desenvolvimento de processos de bancada que possam vir a ser ampliados a um processo industrial adequado.

Uma forma indireta de se imobilizar enzimas, é a imobilização de células já que nem todas as enzimas agem separadamente. Algumas enzimas, como as que catalisam reações endergônicas de sínteses dependem da ação de co-fatores, fontes de energia como NADH e ATP, vias metabólicas complexas ou do metabolismo global da célula, para gerarem um dado produto de interesse industrial. Vale ressaltar que a imobilização de células mantém a enzima em um ambiente adequado, livrando-a de situações adversas como modificações covalentes ou deformação conformacional que podem ocorrer durante o processo de imobilização (Wiseman, 1985).

As enzimas pectinase e inulinase são bem promissoras no desenvolvimento de processos industriais, sendo interessante o seu estudo em diferentes materiais como matrizes de imobilização.

A enzima pectinase é produzida a partir de microrganismos por processos de cultivo dos mesmos em biorreatores estimulando a produção de enzimas excretáveis simulando seu "habitat" natural (Castilho et al., 2000) e que deve ser aproveitada em seu máximo potencial para a diminuição dos custos. Esta enzima é muito utilizada na clarificação de sucos devido à presença da pectina na maioria das frutas, o que dá aos seus sucos aspecto turvo. A pectina ao ser degradada forma monômeros de ácido galacturônico (Figura 1), tornando o suco mais transparente. Para a obtenção desse 
produto a indústria de alimentos investe na pesquisa de processos que utilizem a enzima pectinase, mas estes processos ainda devem ser barateados a nível industrial.

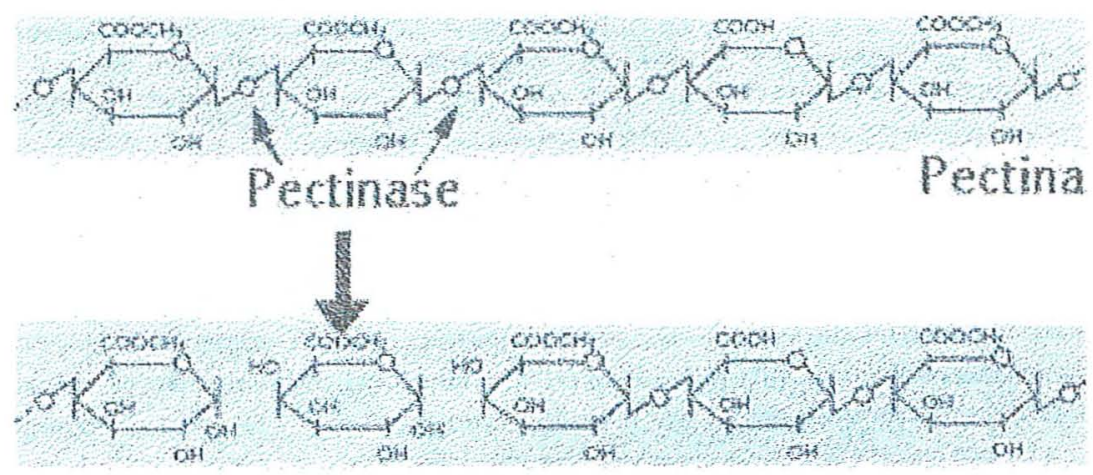

Figura 1 - Estrutura molecular da pectina e sua degradação por pectinase (Adaptado de Camperi, 2002)

Devido a grande atividade pectinolítica e inulinolítica, o microrganismo escolhido para a realização deste trabalho foi a levedura diplóide Kluyveromyces marxiamus linhagem MMIII-41 selecionada no Laboratório de Genética de Leveduras ESALQ/USP a partir da terceira geração do retrocruzamento das linhagens IZ 1339 e IZ 619. Esta seleção foi feita com o objetivo de se obter uma linhagem com altíssima atividade de inulinase e, por conseqüência deste cruzamento obteve-se, não só uma alta atividade para inulinase, como também para pectinase.

A escolha de Klayveromyces marxianus como produtor de inulinase não se deu por acaso. Na classificação de leveduras, uma das mais importantes características observadas é a facilidade de assimilação de determinados carboidratos. Para Kluyveromyces marxianus, o polissacarídeo mais freqüentemente ligado à sua classificação é justamente a inulina. Outro aspecto de extrema importância é a capacidade de exportação desta enzima para o sobrenadante (Pereira, 1989), tornando essa linhagem muito interessante já que processos para a extração de endo-enzimas são mais onerosos e menos eficientes em nível industrial.

Há um crescente interesse neste microrganismo, dada a sua capacidade de excretar enzimas, como também o fato de fermentar inulina. Uma linhagem com esta 
capacidade pode ser muito útil em regiões de semi-árido, onde o Helianthus tuberosus se desenvolve bem, como uma fonte alternativa de produção de etanol. Outro interesse relacionado a esta levedura é a produção da Tequila, já que a agave também é uma planta produtora de inulina, além do mais é a melhor levedura para a produção de xaropes de frutose, conforme descrito adiante.

\subsection{Modos de se imobilizar enzimas}

Existem dois tipos básicos de imobilização: a imobilização ativa, onde a enzima se liga covalentemente à matriz e a imobilização passiva, na qual a enzima é absorvida pela matriz. Dentro desses dois tipos existem pelo menos sete maneiras de se imobilizar enzimas: por ligações covalentes, ligações eletrostáticas, copolimerização, interações hidrofóbicas, aprisionamento em polímeros, aprisionamento lipossomal ou encapsulamento (Figura 2). A imobilização por ligação covalente é o método de imobilização mais extensivamente utilizado (Trevan, 1980). Segundo Laskin (1985), os métodos mais comumente utilizados para a imobilização de enzimas são: Aprisionamento, compreendendo os géis (polímeros orgânicos e inorgânicos), vesículas (microencapsulamento) e membranas semipermeáveis; Absorção (iônica e hidrofóbica); Ligação covalente (grupo funcional reativo) que pode ser realizada pela ligação dos grupos amino terminais das enzimas através de reagentes como carbodiaminas solúveis em água, glutaraldeído, brometo de cianogênio, ésteres de $\mathrm{N}$-hidroxisuccinimida, triazinas, cloreto cianúrico e carbonil diimidazol, pelo grupo carboxil através dos reagentes carbodiaminas solúveis em água e $\mathrm{N}$-etil-5-fenilsoxazólio-3-sulfonato, pelos resíduos tirosil ativados por componentes diazólio e finalmente pelos grupos sulfidril com os reagentes dissulfeto glutationa-2-piridil e ditiobis-5,5'-(2-ácido nitrobenzóico). 


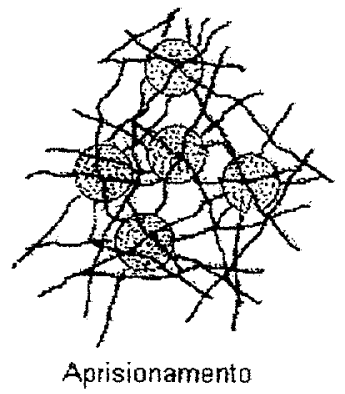

Aprisionamento

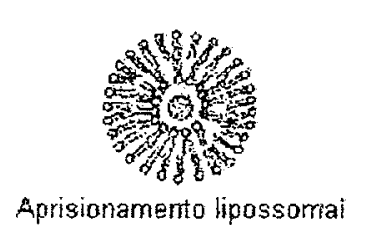

Aprisionamento lipossomai

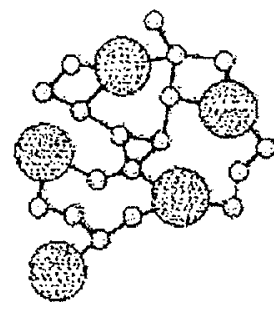

Copolimerização

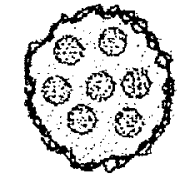

Encapsulamento

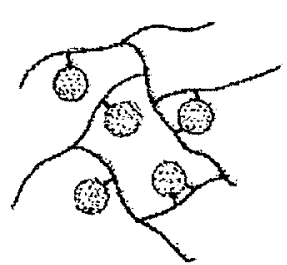

Ligaçôes covalentes

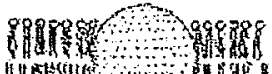

14.

Interaçäo hidrofóbica

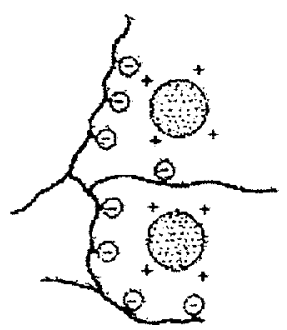

Interaçẫo eletrostática

Enzima
Fosfolipideo
$x$ Polimero matriz

Figura 2 - Possíveis modos de se imobilizar enzimas (adaptado de Trevan, 1980)

\subsection{Tipos de matrizes usadas em Imobilização de enzimas}

São utilizadas como matrizes orgânicas o poliestireno, náilon, resinas de fenolformaldeído e copolímeros acrílicos (como poliacrilamida). Como biopolímeros são usados a celulose, polidextranas (sephadex), agarose, colágeno e quitina e, como suportes inorgânicos, esferas de vidro (porosas e não porosas), sílica, aço inox, óxidos de metais (cerâmicas porosas contendo $\mathrm{ZrO}_{2}, \mathrm{TiO}_{2}, \mathrm{AlO}_{3}, \mathrm{NiO}$ ) e areia (Laskin, 1985; Gemeiner et al., 1994).

Imobilizações realizadas em alginato de cálcio vêm sendo muito utilizadas há algum tempo. As ligações entre as proteínas e o alginato de cálcio são feitas por interações eletrostáticas. $\mathrm{O}$ uso do alginato de sódio é limitado, devido a sua instabilidade em contato com ânions complexos como fosfatos, citrato e lactato, que apresentam grande afinidade com os ions cálcio. Esta instabilidade é também causada pela presença de altas concentrações de íons não gelificantes como $\mathrm{Na}^{+} \mathrm{e} \mathrm{Mg}^{+2}$ (Albarghouthi et al, 2000). Outra restrição da imobilização em alginato é a perda de 
aproximadamente $36 \%$ de enzimas no processo de imobilização (Dashevsky, 1998). Martinsen et al. (1989) demonstraram que há uma perda de $50 \%$ das proteínas durante a primeira hora, entretanto, a taxa de perda é menor quando as moléculas polipeptídicas são maiores. Uma maneira de estabilizar o gel impedindo sua desintegração é a associação com o polissacarídeo quitosana, outra matriz muito utilizada para a imobilização de enzimas. A associação destas duas matrizes resulta em fortes interações entre os resíduos carboxil do alginato e amino terminais do gel-quitosana, formando um complexo polieletrólito que não dissolve na presença de quelantes de $\mathrm{Ca}^{+2}$ (Albarghouthi et al., 2000).

A quitosana $((1 \rightarrow 4)$-2-amino-2-deoxi- $\beta$-D-glucana), encontrada na parede celular de diversos fungos ou derivada da $\mathrm{N}$-deacetilação da quitina $((1 \rightarrow 4)$-2acetoamino-2-deoxi- $\beta$-D-glucana) de crustáceos é muito usada em imobilizações enzimáticas devido a suas propriedades hidrofilicas, de sua bio-compatibilidade, biodegradabilidade, boa porosidade e propriedades antibacterianas (Mima et al., 1983; Martino et al., 1996; Çetinus \& Öztop, 2000; Wu et al, 2001). Também é muito atrativo em termos de custo, já que a quitina é o segundo biopolimero mais abundante na natureza, ficando atrás apenas da celulose (Huang et al., 2000; Kubota et al., 2000 e Juang et al., 2001). Como a quitosana é um polímero linear cationnico de grande peso molecular, é insolúvel em água em valores de pH acima 3,0, portanto, para a sua utilização, deve-se submetê-la a um solvente ácido, como ácido acético (Martino et al., 1996; Kubota et al., 2000) ou o ácido clorídrico (Huang et al., 2000). Quando associada ao glutaraldeido amplia sua capacidade de ligação com polipeptídios e, se dissolvida em ácido acético, forma um gel quitosana que por sua vez, se associa ao glutaraldeído formando um complexo gel-quitosana-glutaraldeído. Esse engloba 20 moles de glutaraldeído para cada unidade monomérica de quitosana, formando uma estrutura complexa com um conglomerado de ligações estáveis consistindo em uma ótima matriz de imobilização, já que as proteínas se ligam ao glutaraldeído pela porção $N$ terminal (Monteiro Jr. e Airoldi, 1999). Outro aspecto interessante é o fato de ser considerada uma matriz polivalente já que em valores de pH menores que 7,0 é carregada positivamente, tornado-a uma matriz com boa capacidade de ligação por interações 
eletrostáticas, aprisionamento (quando na sua forma de gel-quitosana) e por ligações covalentes pelo glutaraldeído (Martino et al., 1996).

Os diversos tipos de náilons são, há muito tempo, utilizados como matrizes para a imobilização de enzimas devido ao seu baixo custo. $O$ náilon já usado em imobilizações de diversas enzimas com bastante sucesso inclusive tendo sido testado com a enzima inulinase (Kim \& Byun, 1982). Suas propriedades químicas e mecânicas, bem como, sua versatilidade na forma, já que podem ser utilizados como redes, filmes, folhas, tubos, esferas, etc. o tomam uma matriz muito procurada e viável (Isgrove et al., 2001).

Os náilons são construções poliméricas de grupos metileno unidos a ligações secundárias amino (Figura 3), que se diferenciam pelo número de grupos metileno nos repetidos segmentos alcano (Hornby e Goldstein, 1976).
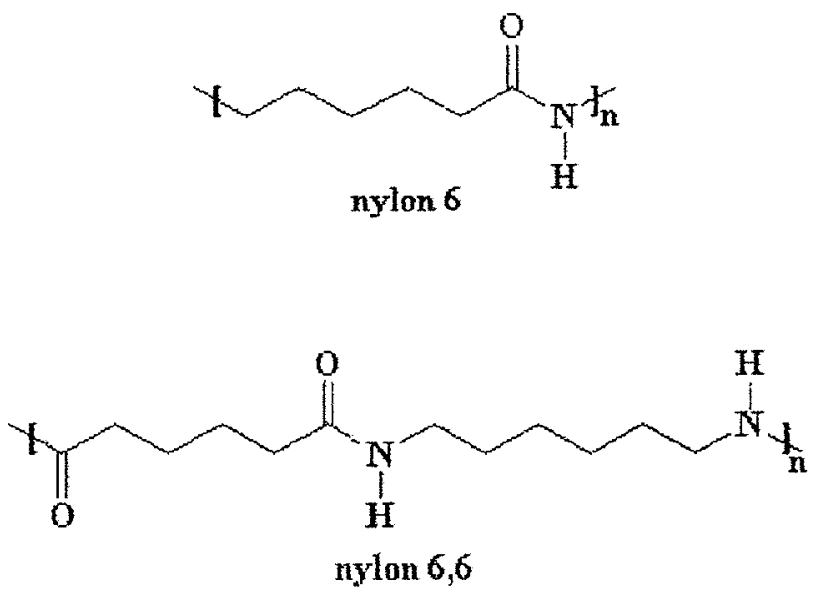

Figura 3 - Estrutura dos náilons 6 e 6,6, os mais utilizados em processos de imobilização

Para se imobilizar enzimas, normalmente o nylon $6^{\circledR}$ é o mais utilizado, por conter em todos os segmentos alcano um número igual de grupos metileno (no caso 5). Outros tipos de nylon ${ }^{(3)}$ contém números variados de grupos metileno em segmentos alcano (Hornby e Goldstein, 1976).

A ligação enzima-náilon é realizada por ligações covalentes, o que apresenta grande vantagem em relação a muitas outras matrizes, pois este tipo de ligação é muito 
estável. Para se imobilizar enzimas nos diferentes tipos de nylon ${ }^{\circledR}$ são necessários três passos (Figura 4). Primeiro é realizada uma hidrólise ácida, com o objetivo de se clivar algumas das ligações amida, para se liberar os grupos amino e carboxil (Isgrove et al., 2001). Depois, como segunda etapa, deve-se introduzir um agente de ligação bivalente como o glutaraldeído para se formar um composto náilon-glutaraldeído que permita uma melhor ligação com as enzimas. A terceira etapa é a adição da enzima que se pretende imobilizar com este composto, formando finalmente a matriz imobilizada (Alkorta et al., 1996 e Hornby e Goldstein, 1976).

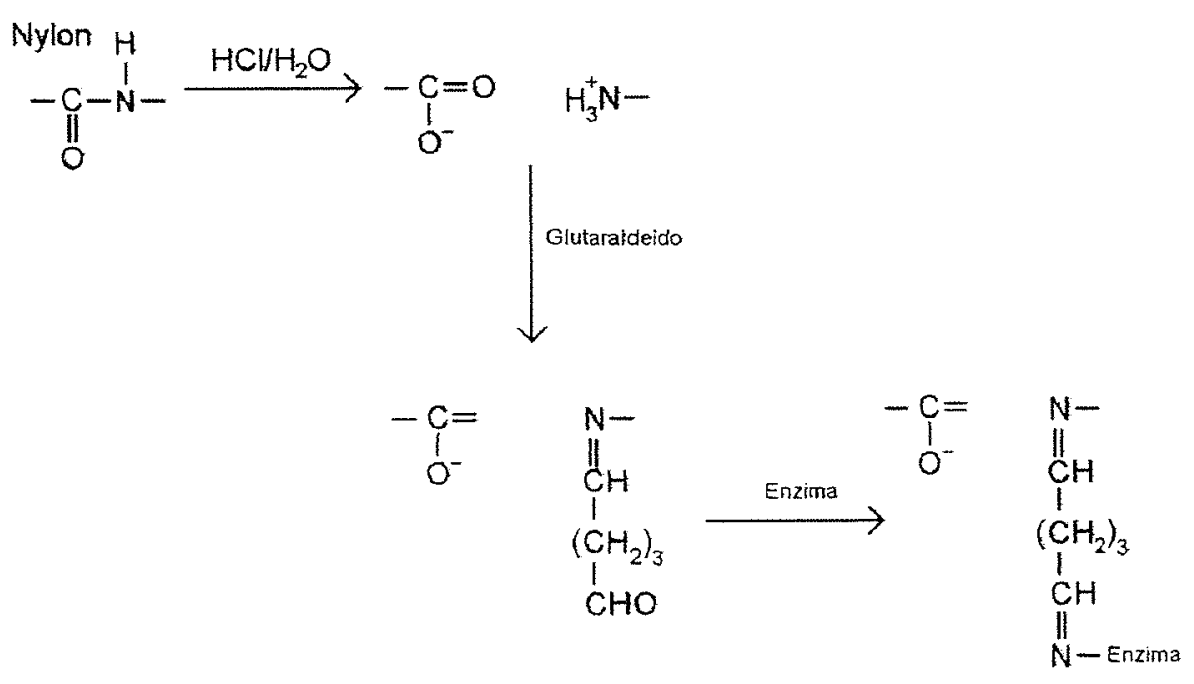

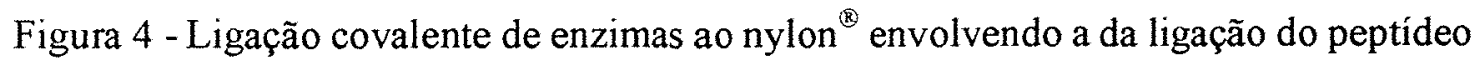
através dos grupos amino primários (adaptado de Hornby e Goldstein, 1976)

Outra possível matriz de imobilização, o poliestireno expandido (poli(1feniletileno)), mais conhecido como isopor, é um aerogel altamente resistente a álcalis e ácidos, bem como, a agentes oxidantes ou redutores. Como o próprio nome sugere é um polímero de moléculas de estireno geralmente lineares (Figura 5), mas podendo ser também amorfo ou cristalino, dependendo dos iniciadores iônicos de polimerização (Billmeyer, 1957). O poliestireno tem sido utilizado com certo sucesso na imobilização 
de enzimas e células na sua forma expandida ou colapsada por ser um polímero inerte e altamente hidrofóbico. Mazuelos et al. (2001) utilizaram este polímero como suporte para a imobilização de bactérias. Prabhu e Chandrasekaran (1997) usaram o poliestireno colapsado por autoclavagem por 15 minutos a $121^{\circ} \mathrm{C}$ como suporte inerte de Vibrio costicola para a produção de L-glutaminase. Wenling et al. (1999) testaram esferas de poliestireno iônico (D201-GM), tratado com $\mathrm{NaOH}$ e ácido cítrico, para imobilizar a enzima parcialmente purificada, inulinase intracelular, em presença de glutaraldeído. Conseguiram uma boa atividade e estabilidade da enzima que por conseqüência da imobilização alterou ligeiramente os valores ótimos de $\mathrm{pH}$ e temperatura para valores mais elevados.

\section{Estireno Poliestirena}

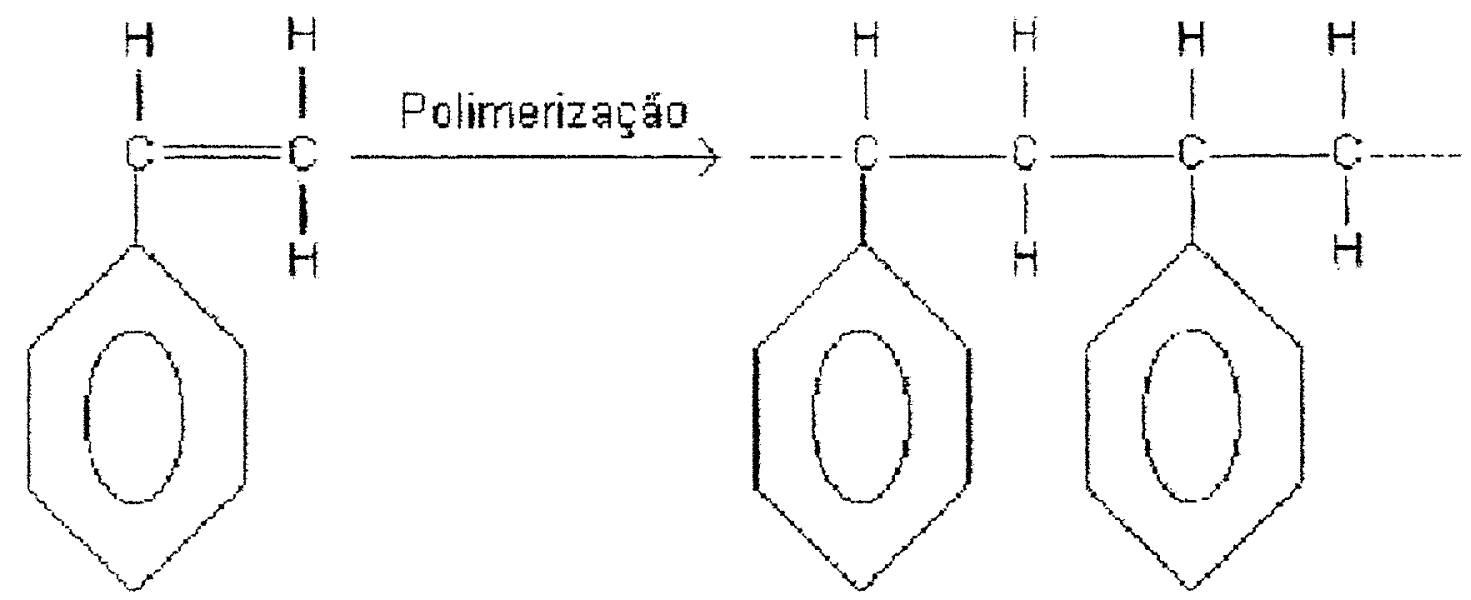

Figura 5 - Estrutura do estireno e seu polímero. Adaptado de Billmeyer (1957)

\subsection{Propriedades das enzimas imobilizadas}

As enzimas imobilizadas têm como propriedades: Alteração da estabilidade, podendo ser aumentada ou diminuída, dependendo de como o novo ambiente afeta sua tendência a desnaturação. Uma enzima imobilizada pode estar protegida do ataque por outras enzimas com atividade proteolítica; Alteração da faixa de $\mathrm{pH}$ cuja atividade se mantém estável, podendo aumentar em até duas unidades de $\mathrm{pH}$, dependendo da enzima 
e do substrato no qual ela foi imobilizada; Alteração do $K_{m}$ aparente, tendo sido demonstrado o seu aumento nas enzimas papaína e fosfatase alcalina imobilizadas em membranas "collodion". A $V_{\text {máx (velocidade máxima) geralmente é reduzida devido à }}$ dificuldade de difusão do substrato através da matriz, principalmente quando a enzima está imobilizada por aprisionamento no interior da mesma (Palmer, 1981).

\subsection{Aplicação das enzimas imobilizadas}

A grande vantagem da imobilização de enzimas é o aumento de sua estabilidade e facilidade na sua reutilização, já que, estando presas a uma matriz, as enzimas não se perdem junto ao produto, facilitando inclusive a purificação do mesmo após o processo. $O$ importante em um processo industrial é a obtenção de uma maior quantidade, a melhor qualidade, o menor tempo e o menor custo possivel para qualquer produto, e a imobilização de enzimas é o melhor caminho existente para produtos que dependem de um processo enzimático (Trevan, 1980; Bergamasco et al. 2000).

\subsection{Kluyveromyces marxianus}

O gênero Kluyveromyces possui 18 espécies, sendo elas, células com forma esferoidal, elipsoidal, cilindroidal ou elongada, apresentando brotamento multilateral. Muitas espécies possuem pseudomicélio, ascósporos do tipo oblongo, crescentiforme, reniforme, esferoidal ou elipsoidal (Barnett et al., 1990). O número de ascósporos no asco é variável, podendo ser de um a dezesseis. Em relação às características fisiológicas, todas as espécies apresentam grande capacidade fermentativa. Metade das espécies consegue fermentar em meio de cultura com mais de $50 \%$ de glicose, não crescem na ausência de vitamina, não utilizam nitrato como fonte de nitrogênio, são resistentes a cicloexamida e diversas espécies possuem pigmento vermelho (Pereira, 1989).

A levedura Kluyveromyces marxianus é hiper produtora das enzimas inulinase e pectinase, bem como apresenta ótima atividade de invertase o que permite o 
desenvolvimento de um processo único que permita a hidrólise dos três substratos (Thonart et al, 1988; Rikir et al., 1990).

\subsection{Extrato enzimático de Kluyveromyces marxianus}

Estudos realizados por Pereira (1989), no Laboratório de Genética de Leveduras ESALQ/USP, com o sobrenadante de $K$. marxianus, sugerem a presença de uma única enzima, com peso molecular de $94 \mathrm{kDa}$ e presença de glicosilação. Segundo CruzGuerrero, (1995) a levedura $K$. marxianus produz a inulinase E.C. 3.2.1.7, de forma que se supõe que seja esta a enzima em questão. Porém outros autores descreveram a inulinase 2,1 $\beta$-D-frutanoidrolase E.C. 3.2.1.7, extraída de Aspergillus versicolor com diversos pesos moleculares variando de $200 \mathrm{kDa}$ (Pessoa Jr. \& Vitolo, 1998), a $230 \pm 20$ $\mathrm{kDa}$ (Kochhar et al., 1997) e a inulinase extraída de Aspergillus candidus com peso molecular de $54 \pm 4 \mathrm{kDa}$ (Kochhar et al., 1999). Em um trabalho realizado com diversos microrganismos o peso molecular foi de $250 \pm 10 \mathrm{kDa}$ (Gupta et al., 1994).

$\mathrm{O}$ ponto isoelétrico determinado para a inulinase de Candida kefyr varia de 3.9 a 4.3 sendo esta enzima altamente estável em solução aquosa entre valores de $\mathrm{pH}$ de $3.0 \mathrm{a}$ 7.0 perdendo a estabilidade abaixo de pH 3.0 e acima do pH 7.5 (Pessoa Jr. \& Vitolo, 1998). O ponto isoelétrico da inulinase de Kluyveromyces marxianus é de 4.3 (ensaios prévios realizados no Laboratório de Genética de Leveduras ESALQ/USP).

A inulinase é considerada uma enzima termoestável de grande utilidade em aplicações industriais (Ettalibi \& Baratti, 2001). A meia vida da enzima em reator é de aproximadamente 32 dias (Wei et al., 1999). No trabalho de Pessoa Jr. \& Vitolo (1999), a enzima mantida a $4^{\circ} \mathrm{C}$ manteve $100 \%$ da atividade por pelo menos 22 meses tanto em enzimas livres como em enzimas imobilizadas, se conservada a $-18^{\circ} \mathrm{C}$, perde pelo menos $10 \%$ da sua atividade, provavelmente por danos causados pelo congelamento e descongelamento. Porém ao confrontar seus dados aos de outros autores Pessoa Jr. \& Vitolo (1999), encontraram estabilidade de apenas 32 dias a $4^{\circ} \mathrm{C}$. O fato é que, independente da diferença dos dados apresentados, pode-se considerar essa enzima 
altamente estável, o que aumenta seu potencial nas aplicações práticas (Pessoa Jr. \& Vitolo, 1999).

$\mathrm{O}$ sobrenadante de $K$. marxianus $\mathrm{MMIII}-41$ apresenta atividade inulinolitica e pectinolítica ótima entre os valores de $\mathrm{pH} 2.5$ e 8.0 sendo 6.5 o melhor valor. A temperatura ideal para esta enzima está entre 30 e $40^{\circ} \mathrm{C}$ sendo fortemente inativada a $50^{\circ} \mathrm{C}$ tornando-se totalmente inativa a $60^{\circ} \mathrm{C}$ (Pereira, 1989). Rikir et al., (1990), em seus experimentos utilizaram como ideais o $\mathrm{pH} 5,0$ e temperatura de $37^{\circ} \mathrm{C}$, tanto para as atividades de inulinase e pectinase, como para invertase. Sakai, T. (1988), caracterizou a atividade de poligalacturonase em Kluyveromyces fragilis um $\mathrm{pH}$ ótimo de 5,0 e temperatura ótima $60^{\circ} \mathrm{C}$, termo-estabilidade acima de $40^{\circ} \mathrm{C}$ e estabilidade em valores de $\mathrm{pH}$ variando de 2 a 8 e ainda um $\mathrm{Km}$ de $6,6(\mathrm{mg} / \mathrm{mL})$.

A grande atividade extracelular observada em $K$. marxianus se deve a pequena capacidade de retenção do envoltório desta levedura, não havendo nenhum sistema de exportação através da membrana (Pereira, 1989), também se pode aumentar a permeabilidade da membrana pode ser aumentada através de um tratamento térmico, 0 que permite a sua utilização em processos de imobilização de células mortas em um processo de hidrólise (Rikir et al., 1990). Isso torna essa levedura muito interessante do ponto de vista prático, já que um processo de extração das enzimas seria muito custoso em termos de tempo e dinheiro.

Em $K$. marxianus as proteínas (enzimas) são excretadas na mesma velocidade em que são produzidas, ocorrendo diminuição na excreção quando há um aumento na exportação de outra proteína (Pereira, 1989). Talvez a quantidade de proteínas excretadas seja regulada por competição pelos processos de modificações póstraducionais como a clivagem do peptídeo sinal e a glicosilação (Deshaies et al., 1989).

\subsection{Inulinase e a produção de xaropes de frutose}

A inulina é uma glicofrutana linear de fórmula básica G.F.Fn, composta por pelo menos 35 moléculas de frutose e uma terminação $\alpha$-D-glicopiranose idêntica à da sacarose, por isso é muito mais eficiente que outros polissacarídeos na produção de 
xaropes de frutose (Laguna, 1986), pois produz um xarope com $85 \%$ de D-frutose e $15 \%$ de D-glicose (Wei et al., 1999).

Cada molécula de inulina apresenta solubilidade diferente em água, pois, geralmente o comprimento da cadeia é muito variável. As moléculas menores são mais solúveis que as moléculas maiores. A baixas temperaturas a solubilidade diminui para todas as moléculas sendo as de tamanho maior, mais facilmente dissolvidas quando se aumenta a temperatura e novamente precipitadas quando a temperatura decresce. A atividade de água também varia conforme o tamanho de sua molécula, além disso, quando pura, se apresenta sob a forma de um pó branco altamente higroscópico, com capacidade de reter água semelhante à do sorbitol, portanto, maior que a da sacarose, o que torna necessário o armazenamento em local seco e fechado. A inulina pode ser hidrolisada por ácido em temperaturas elevadas ou via enzimática (Capito, 2001).

A inulinase (endoinulinase ou exoinulinase), utilizada para a hidrólise de inulina, é outra enzima de interesse industrial que pode ser produzida por diversos microrganismos. Uma grande variedade de enzimas com capacidade de hidrolisar as ligações $\beta-1,2$ frutofuranosidase (ligações da sacarose e da inulina) já foram identificadas. Estas podem ser classificadas em três grupos, de acordo com suas atividades em polissacarídeos de diferentes graus de polimerização (GP). No grupo 1, temos as verdadeiras $\beta-1,2$ frutano - frutano - hidrolases, com alta atividade em inulina e extremamente baixa em sacarose. Estas enzimas ocorrem nos tubérculos de Helianthus tuberosus, e estão envolvidas na utilização das reservas pelo vegetal. No segundo grupo, encontramos as enzimas com atividade $\beta$-D frutanofuranosídio - frutano - hidrolase, com relação, hidrólise da sacarose em relação à inulina $(\mathrm{S} / \mathrm{h})$, de aproximadamente 14.000 , como a invertase da Saccharomyces cerevisiae. O terceiro grupo é o que apresenta relação (S/I) nos valores intermediários sendo, muito menores, que os da invertase (Pereira, 1989).

Os microrganismos mais estudados em relação à produção de inulinase são: Kluyveromyces fragilis, Kluyveromyces marxianus, Hansenula polymorpha, Pichia fermentan, P. polymorpha, Debraryomyces castelli (Gupta et al., 1994), Aspergillus niger (Nakamura et al., 1995; Cruz et al., 1998), Pseudomonas sp. (Yun et al., 1997), 
Aspergillus versicolor (Kochhar et al., 1997), Candida kefyr (Pessoa Jr. \& Vitolo, 1998), Xanthomonas sp. (Park et al., 1999), Kluyveromyces sp. (Wei et al., 1999), Aspergillus candidus (Kochhar et al., 1999), Aspergillus ficuum (Ettalibi \& Baratti, 2001). As leveduras do gênero Kluyveromyces apresentam grande interesse industrial devido às características fisiológicas e acessibilidade genética e pertencerem ao grupo de leveduras seguras para o consumo (Scanavini et al., 2001).

Muitos autores citam linhagens de Kluyveromyces marxianus como altamente produtoras de inulinase (Rikir et al., 1990; Cruz-Guerrero, 1995; Pessoa Jr. \& Vitolo, 1999), independentemente da fonte de carbono, pois há produção dessa enzima mesmo na presença de outros açúcares como frutose, glicose, sacarose. A inulinase é produzida de maneira constitutiva e, independente da fonte de carbono, são necessárias a presença de extrato de levedura e de peptona no meio de crescimento para a adequada produção desta enzima (Pessoa Jr. \& Vitolo, 1999).

Estudos com esta enzima são de grande importância, pois a inulinase possibilita a produção de xaropes de frutose a partir de fructoligossacarídeos dos quais o mais abundante é o açúcar inulina (Figura 7). Os frutoligossacarídeos estão presentes em diversas plantas, como alcachofra, banana, bardana, camásia (liliácea), grãos de centeio e cevada, agave (Agave americana, Agave Vera cruze), nas raízes do aspargo (Asparagus officinalis), chicória (Cichorium intybus), nos bulbos de cebola, alho e alhoporro, nas folhas da alface (Lactuca sativa) e da beterraba doce (Crinum longifolium) nas raizes de cercefi e yakon (Polymnia sonchifolia) e nos tubérculos de Helianthus tuberosus ou alcachofra de Jerusalém (UFSC, 2002; Frank, 2002 e Yun, 1996). A Tabela 1 mostra as quantidades de inulina e oligofrutoses encontradas em alguns vegetais de consumo comum. 
Tabela 1. Conteúdo de inulina e outros oligofrutanos em alguns alimentos ${ }^{1}$

\begin{tabular}{|c|c|c|c|c|}
\hline Fonte & Nome Científico & $\begin{array}{c}\text { Parte } \\
\text { comestível }\end{array}$ & $\begin{array}{c}\text { Inulina } \\
(\%)\end{array}$ & $\begin{array}{c}\text { Oligofrutanos } \\
(\%)\end{array}$ \\
\hline Alcachofra & Cynara scolymus & Folhas & $3-10$ & $<1$ \\
\hline Alho & Allium sativum & Bulbo & $9-16$ & $3-6$ \\
\hline Alho porro & Allium ampeloprasum & Bulbo & $3-10$ & $2-5$ \\
\hline Almeirão & Cichorium intybus & Folha & $15-20$ & $5-10$ \\
\hline Aspargo & Asparagus officinalis & Talo & $1-30$ & $1-20$ \\
\hline Banana & Musa acuminata & Fruto & $0,3-0,7$ & $0,3-0,7$ \\
\hline Bardana maior & Articum lappa & Raizes & $3,5-4$ & $(--)$ \\
\hline Cebola & Allium cepa & Bulbo & $2-6$ & $2-6$ \\
\hline Centeio & Secale sativa & Grãos & $0,5-1$ & $0,5-1$ \\
\hline Cevada & Hordeum vulgare & Grãos & $0,5-1,5$ & $0,5-1,5$ \\
\hline Dente de leão & Taraxacum officinale & Folhas & $12-15$ & $(--)$ \\
\hline Trigo & Triticum aestivum & Grãos & $1-4$ & $1-4$ \\
\hline Tupinambur & Helianthus tuberosus & Tubérculos & $16-20$ & $16-20$ \\
\hline Yakon & Polymnia sonchifolia & Raízes & $3-19$ & $3-19$ \\
\hline
\end{tabular}

Fonte: Capito, 2001.
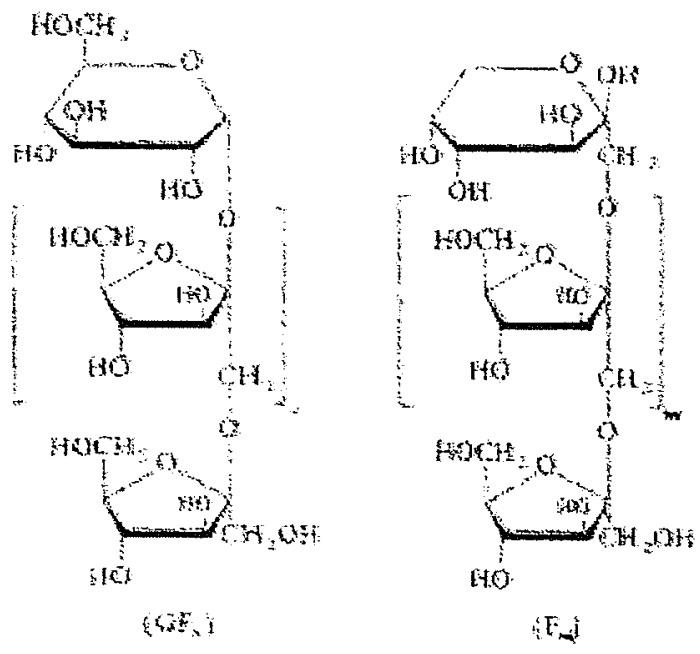

Figura 6 - Estrutura molecular da inulina (Frank, 2002) 
No ano de 1983 a Pepsi Co. Inc. já substituía 50\% da sacarose de seus produtos por xarope de milho com alta concentração de frutose (HFCS). A partir de novembro de 1984 o HFCS passou a ser o único edulcorante nos refrigerantes da Coca-cola e Pepsicola nos Estados Unidos (Gaspari, 1998) A frutose produzida pela biotecnologia já conquistou cerca de $10 \%$ do mercado mundial (Altieri, 2002).

A alcachofra de Jerusalém é conhecida por diversos nomes como cardão e tupinambur no Brasil, Jerusalém Artichoke ou sunchoke nos Estados Unidos, girasole pelos índios americanos e finalmente tupinambour pelos franceses (Figura 7). É a planta que apresenta a maior produtividade em inulina conhecida e por isso a mais importante para a produção de xaropes de frutose do tipo UHFS "Ultra High Fructose Syrups" (Byun \& Nahm, 1978). Os tubérculos desta planta são alongados com casca branca ou vermelha, dependendo do tipo de solo em que é cultivada (CEAGESP, 2001) conforme se pode observar na Figura 7. Os tubérculos apresentam 20 a $26 \%$ de matéria seca, da qual 75 a $82 \%$ são carboidratos solúveis, $13 \%$ celulose e hemicelulose, 6 a $8 \%$ de compostos nitrogenados (proteínas), 1 a 5\% de cinzas, e lipídeos em concentrações menores que $1 \%$ (Oliveira, 1999). Mesmo correspondendo a, no máximo, 15\% dos carboidratos, a inulina pode ser considerada como o carboidrato do H. tuberosus, uma vez que os polímeros restantes, de menor tamanho, são da mesma composição e com o mesmo tipo de ligações (Oliveira, 1999). Com esta composição, a frutose corresponde a 75 a $98 \%$ dos açúcares redutores totais, sendo o restante, glicose (Byun \& Nahm, 1978; Oliveira, 1999). A variação na concentração de frutose se dá pela variação do peso molecular da molécula de inulina nas diferentes estações do ano sendo a melhor relação frutose/glicose no outono (Byun \& Nahm, 1978; Kim \& Byun, 1982) e a pior no verão (Gaspari, 1998). No Brasil, a produção de alcachofra de Jerusalém é de 90 a 120 toneladas por hectare por ano, em até quatro safras, de tubérculos ricos em inulina (Laguna, 1986). Portanto, nossa produtividade é muito boa comparada à norte americana que é de no máximo 66,71 toneladas por hectare no estado do Oregon (OREGON STATE UNIVERSITY, 2002), o que nos traz uma grande vantagem competitiva. Se compararmos a produtividade do tupinambur com a produtividade média da cana de açúcar que é de 85 toneladas por hectare anuais, dados da Federação da Agricultura do 
Estado de São Paulo (1999), veremos que esse vegetal tem enorme potencial na produção de açúcares para exploração comercial. Estudos relacionados ao cultivo de Helianthus tuberosus vêm sendo realizados na Universidade do Ceará, com dados promissores para a região (Gaspari, 1998).

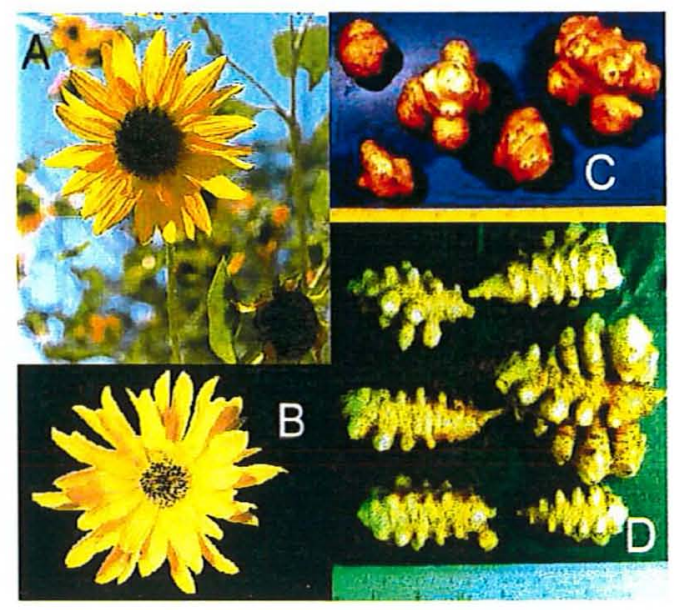

Figura 7 - Aspecto geral da alcachofra de Jerusalém. Planta florida (A), detalhe da inflorescência (B), tubérculos com casca vermelha (C) e tubérculos brancos (D)

A frutose tem diversas aplicações na indústria de alimentos devido as suas propriedades organolépticas. Apresenta baixa cristalização, são menos viscosas que a sacarose e tem alto poder adoçante. Soluções de frutose possuem maior pressão osmótica que soluções de sacarose na mesma concentração, provocando menos cáries dentárias, podendo ser consumida por diabéticos, pois é absorvida sem a intervenção da insulina, mascarando o sabor amargo da sacarina quando associada a esta (Laguna, 1986; Pessoa Jr. \& Vitolo, 1998; Gaspari, 1998). A frutose também pode ser associada à aceleração do metabolismo de etanol, bem como ao aumento da absorção de ferro através da quelação do mesmo formando um complexo ferrofrutose (Gaspari, 1998). 


\subsection{Pectinase em Kluyveromyces marxianus}

Dentre os microrganismos produtores de pectinase destacam-se os fungos filamentosos como o Aspergillus niger (Castilho et al., 2000), o Rhizomucor pusillus, Fusarium equiseti, Alternaria alternata, Fusarium lateritium, $F$. oxysporum entre outros (Henriksson et al., 1999). Dentre as leveduras, Kluyveromyces marxianus é a mais ativa na secreção de enzimas pectinolíticas (Schwan et al., 1997), de grande importância para a decomposição da camada péctica em torno de sementes de cacau e café no seu processamento (Blanco et. al., 1999). Porém essa atividade em Kluyveromyces marxianus não é um complexo enzimático como em outros microrganismos, mas uma atividade simples, apenas poligalacturonase, que degrada ácido poligalacturônico em ácido oligogalacturônico e monogalacturônico (Schejter e Marcus, 1988; Rikir et al., $1990)$.

A pectinase é também muito utilizada como enzima complementar no processo de hidrólise de farelo de mandioca para a obtenção de etanol a partir da fermentação do caldo hidrolisado (Leonel \& Cereda, 1999 e Sriroth et al., 2000).

Não só a pectina dos vegetais é degradąda pela pectinase, mas também pectatos que são formados por ácido poligalacturônico não metilado (Worthington Biochemical Corporation, 2001). Outra utilização estudada é o tratamento de tecidos vegetais (maceração) pela degradação da lamela péctica resultando em uma suspensão celular com baixa perda de material intracelular (Dinnella et al., 1998) ou em fibras vegetais para a fabricação de tecidos (Henriksson et al., 1999).

As poligalacturonases encontradas no gênero Kluyveromyces foram classificadas como endopoligalacturonase E.C. 3.2.1.15 e exopoligalacturonase E.C. 3.2.1.67. A hidrólise resultante da atividade dessas enzimas não é completa originando uma mistura de ácidos, mono, di e trigalacturônico (Luh and Phaff, 1954 a e b; Schejter e Marcus, 1988), e a atividade é tão maior quanto menor for o grau de esterificação do substrato, de forma que vão sendo liberados os monômeros de ácido galacturônico da extremidade do polímero (Sanchez, 1984). Na espécie K. fragilis foi caracterizada a temperatura ótima de atividade para essas enzimas variando de 55 a $60^{\circ} \mathrm{C}$ e pH variando de 3.5 a 4.0 , 
sendo tanto a temperatura quanto o $\mathrm{pH}$, muito próximos aos observados em poligalacturonases (PG) de fungos (Luh and Phaff, 1951). A produção de PG em $K$. marxianus é estritamente relacionada com as condições de aeração, sendo muito produtiva em anaerobiose e apresenta ausência ou baixa produção em altas condições de aeração (Blanco et. al., 1999). 


\section{MATERIAL E MÉTODOS}

\subsection{Microrganismo:}

Para a produção das enzimas inulinase, invertase e pectinase foi necessário trabalhar com uma linhagem que produzisse em grande quantidade destas enzimas. Para tanto foi utilizada, a levedura Kluyveromyces marxianus MMIII-41 selecionada por retrocruzamento das linhagens de Kluyveromyces marxianus IZ 1339 e IZ 619 no Laboratório de Genética de Leveduras ESALQ/USP.

A sigla MMII-41 significa: colônia número 41 da terceira geração do cruzamento das duas linhagens acima citadas selecionada em meio mínimo pela auxotrofia a metionina e arginina (Figura 8). 


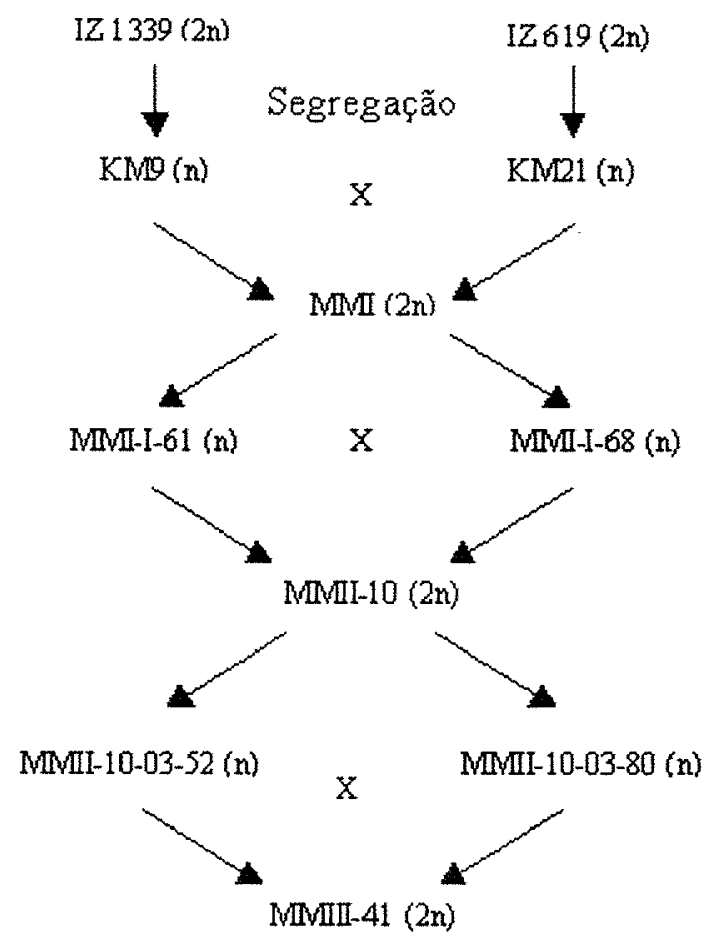

Figura 8 - Esquema da obtenção da linhagem Kluyveromyces marxianus MMIII-41 produtora de inulinase

A linhagem MMIII-41 é produtora de inulinases produzidas por diferentes alelos, por isso chamadas: tipo A e tipo B, o que a torna mais eficiente na produção da inulina. Como conseqüência desse cruzamento obteve-se nesta linhagem uma altíssima capacidade de produção de poligalacturonase (Gaspari, 1998).

\subsection{Colunas de análise enzimática:}

A análise de atividade enzimática foi realizada através da metodologia de Somogyi e Nelson, através formação de açúcares redutores a partir substrato testado (Somogyi, 1945). Para isso as condições de reação foram controladas quanto ao $\mathrm{pH}$ e temperatura.

Construiu-se uma coluna especial para a análise enzimática com relação altura/diâmetro (H/D) igual a 6,818, em acrílico e com camisa, para a manutenção da 
temperatura em $38^{\circ} \mathrm{C}$, temperatura ideal para a enzima em questão (Figura 9) e outra coluna em vidro com a altura/diâmetro (H/D) igual a 4,125 com a mesma finalidade.

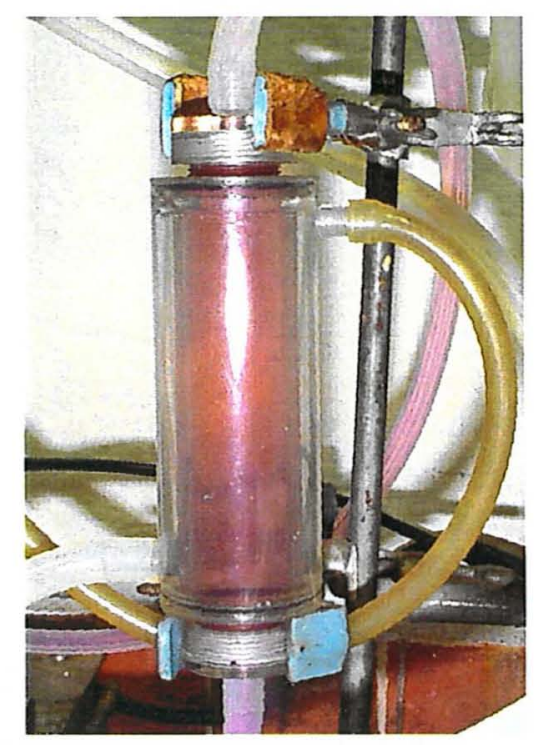

Figura 9 - Coluna em acrílico desenvolvida para a análise enzimática. A região em rosa é a área de inclusão da enzima imobilizada, A área em volta é a camisa para a circulação de água para a manutenção da temperatura

\subsection{Estoque da levedura:}

A linhagem foi sempre cultivada em meio YEPS 3\%, em frascos erlenmeyer sob agitação em "Shaker" (condição de aerobiose), por $48 \mathrm{~h}$ a $30^{\circ} \mathrm{C}$. O meio YEPS consiste de $0,5 \%$ de peptona, $0,5 \%$ de extrato de levedura e $3 \%$ de sacarose.

$\mathrm{O}$ estoque de levedura (para trabalho) foi feito em tubos de eppendorf esterilizados devidamente identificados, $500 \mu \mathrm{L}$ da suspensão de levedura e $500 \mu \mathrm{L}$ de solução glicerol a $30 \%$ esterilizado, sendo congelado imediatamente em freezer a $-80^{\circ} \mathrm{C}$.

Os tubos de eppendorf foram então, armazenados em uma caixa apropriada para o acondicionamento dos mesmos e resistente a baixas temperaturas. Esta caixa era identificada com o nome da linhagem, data de preparo do estoque e nome do operador. 
Cada tubo de eppendorf só era novamente descongelado na hora de se preparar inóculo para uma nova cultura.

\subsection{Obtenção do sobrenadante de Kluyveromyces marxianus MMII-41.}

A levedura Kluyveromyces marxianus $\mathrm{MMIII}-41$ foi inoculada a partir de um estoque armazenado em tubos de eppendorf em um frasco erlenmeyer de $500 \mathrm{~mL}$ contendo $100 \mathrm{~mL}$ do meio YEPS $3 \%$, sob agitação por 48 horas a $30^{\circ} \mathrm{C}$ para o crescimento das leveduras.

A cultura foi transferida para tubos de centrífuga de $50 \mathrm{~mL}$ (Falcon) para a centrifugação por cinco minutos a $3.000 \mathrm{~g}$ para a total precipitação das células da levedura (Byun \& Nahm, 1978).

O sobrenadante contendo a enzima foi coletado e utilizado nos experimentos.

\subsection{Pré-Purificação do sobrenadante de Kluyveromyces marxianus MMIII-41 por precipitação com sulfato de amônio.}

O sobrenadante obtido da centrifugação da cultura de Kluyveromyces marxianus, foi concentrado a vácuo e ajustado à concentração de $100 \mu \mathrm{g} / \mathrm{mL}$. Ao sobrenadante foi adicionado o sulfato de amônio à saturação de $70 \%$. Centrifugou-se a $10.000 \mathrm{~g}$ por 20 minutos de modo a serem precipitadas proteínas indesejáveis. O sobrenadante foi retirado e submetido a uma segunda precipitação com $90 \%$ de sulfato de amônio para a precipitação total das proteínas de interesse. O pellet obtido foi ressuspendido em tampão fosfato $\mathrm{pH} 7.0$ e dialisado no mesmo tampão por $24 \mathrm{~h}$ a $4^{\circ} \mathrm{C}$ para a retirada do sulfato de amônio. 


\subsection{Pré-Purificação do sobrenadante de Kluyveromyces marxianus MMIII-41 por precipitação isoelétrica.}

O sobrenadante obtido da centrifugação da cultura de Kluyveromyces marxianus, foi submetido a uma purificação prévia através da precipitação das proteínas com pontos isoelétricos superiores ao da enzima de interesse. $\mathrm{O}$ valor de $\mathrm{pH}$ foi reduzido até 4,3 pela adição de ácido clorídrico $0,1 \mathrm{~N}$;

O extrato então, foi submetido a uma centrifugação a $3.000 \mathrm{~g}$ por cinco minutos, para a total precipitação das proteínas que tenham pontos isoelétricos acima de 4,3. Após a centrifugação o sobrenadante foi coletado e o seu valor de $\mathrm{pH}$ ajustado para 7.0, utilizando-se o $\mathrm{NaOH} 0,1 \mathrm{~N}$.

\subsection{Conservação da enzima para os diferentes ensaios}

O extrato pré-purificado por precipitação isoelétrica foi, congelado e concentrado a vácuo, dialisado para a retirada do excesso de sais e, logo em seguida, submetido a uma análise de proteínas totais pelo método de Bradford (Bradford, 1976). O extrato foi diluído até a concentração padrão de $100 \mu \mathrm{g} / \mathrm{mL}$ e aliqüotado em quantidades compatíveis ao montante utilizado em cada ensaio e armazenado temperatura próxima ao valor de $0^{\circ} \mathrm{C}$. Todos os ensaios foram realizados com o mesmo sobrenadante na mesma concentração de proteína para diminuir o erro experimental. Para todas as matrizes, as enzimas foram imobilizadas seguindo os respectivos protocolos, todos descritos a seguir, de forma idêntica, para todos os ensaios. As eventuais diferenças, neste caso, se deram pelo estado de conservação da enzima nestas condições.

\subsection{Teste de atividade pectinolítica}

O teste para a determinação de atividade pectinolítica consistiu no preparo de placas de petri contendo meio de cultura com $0,5 \%$ de peptona, $0,5 \%$ de extrato de levedura, $3 \%$ de pectina e $0,01 \%$ de vermelho congo (cujo $\mathrm{pH}$ de viragem é 3,0 ), o $\mathrm{pH}$ 
foi corrigido para 7,0. Em uma mesma placa, estriou-se culturas das leveduras, Kluyveromyces marxianus MMIII-41 e Saccharomyces cerevisiae Fleischmann de forma a ser possivel visualizar um halo de coloração escura demonstrando a formação de ácido monogalacturônico decorrente da degradação da pectina. Utilizou-se levedura $S$. cerevisiae Fleischmann como padrão negativo.

\subsection{Ensaios de afinidade enzimática e caracterização}

Para a determinação da afinidade enzimática aos substratos, foram realizados ensaios objetivando determinar os valores de $\mathrm{Km}$ com a concentração protéica total aproximada de $100 \mu \mathrm{g} / \mathrm{mL}$ frente aos substratos inulina e sacarose, nas concentrações de 0,$33 ; 0,66 ; 3,33 ; 6,66,13,33$ e $20,0 \%$ e vários testes com pectina em diversas faixas de concentração $(0,007$ a 0,$0667 ; 0,667$ a 6,667 e 0,333 a 3,333$)$. Os testes foram realizados em três diferentes tempos 15,30 e 45 minutos.

A determinação de açúcares redutores formados foi determinada pelo método de Somogyi e Nelson (Somogyi, 1945). Os dados obtidos foram analisados com a utilização do programa "Hyperbolic Regression Analysis of Enzyme Kinetic Data" versão 1.1 desenvolvido na Universidade de Liverpool (Easterby, 2003) e calculados por Hanes, Lineaweaver-Burk, Michaelis-Menten e Eadie-Hofstee.

$\mathrm{Na}$ tentativa de se caracterizar melhor a(s) enzima(s) contida(s) no sobrenadante de Kluyveromyces marxianus MMIII-41, foram feitos géis de poliacrilamida não desnaturantes, para que fosse possível determinar quais bandas eletroforéticas apresentavam atividade para cada uma dos substratos estudados, no caso inulina, sacarose e pectina. Para isso metade do gel foi corado por "Coomassie blue". Na outra metade cada banda foi eluida separadamente e testada com os três substratos supra citados.

Também foram feitos géis com SDS para a determinação do peso molecular das proteinas presentes no sobrenadante que apresentaram alguma atividade. 


\subsection{Imobilização da enzima em alginato de sódio}

O método descrito foi ajustado por Gaspari (1998). O sobrenadante de Kluyveromyces marxianus MMII-41 pré-purificado na concentração protéica aproximada de $100 \mu \mathrm{g} / \mathrm{mL}$, foi imobilizado em alginato através da polimerização de uma suspensão de $2 \%$ de alginato dissolvidos no sobrenadante.

A mistura do alginato foi feita vagarosamente para se evitar a formação de corpos muito densos de forma a se obter uma mistura bem homogênea.

Utilizando-se bomba peristáltica, a suspensão de enzimas contendo o alginato foi gotejada em uma solução de $\mathrm{CaCl}_{2} \quad 4 \%$ sob agitação formando-se pérolas de aproximadamente $3 \mathrm{~mm}$ de diâmetro. As esferas foram lavadas com água deionizada ( $\mathrm{pH}$ aproximadamente 7.0) para a eliminação das enzimas não imobilizadas.

\subsection{Imobilização da enzima em quitina}

O sobrenadante de Kluyveromyces marxianus MMIII-41 pré-purificado na concentração protéica aproximada de $100 \mu \mathrm{g} / \mathrm{mL}$, foi imobilizado em quitina de lagosta cedida pelo Prof. Dr. Afrânio Garcia (PADETEC - UFC, Parque de Desenvolvimento Tecnológico da Universidade Federal do Ceará). A quitina utilizada foi preparada por Gaspari (1998) por uma desmineralização pela adição de $\mathrm{HCl} 22 \%$ a $20^{\circ} \mathrm{C}$ e depois desproteinizada com $\mathrm{KOH}$ a $28 \%$ em uma temperatura de $90^{\circ} \mathrm{C}$. Esta quitina foi então moída em cadinho e peneirada em malha de 0,58 mesh.

A proporção utilizada foi de $1 \mathrm{~g}$ de quitina para $5 \mathrm{~mL}$ de solução enzimática (sobrenadante pré-purificado) em pH 7.0. A mistura foi mantida por $24 \mathrm{~h}$ sob agitação constante a $30^{\circ} \mathrm{C}$. Depois de preparada, a mistura foi submetida a análise enzimática frente ao substrato fornecido pela adição do extrato de Helianthus tuberosus desproteinizado por precipitação e o excesso mantido em refrigerador a $4^{\circ} \mathrm{C}$. 


\subsection{Imobilização da enzima em poliestireno expandido (Isopor)}

As esferas de $1 \mathrm{~mm}$ de poliestireno expandido foram colocadas em contato com uma solução de glutaraldeído $2,5 \%$ a $30^{\circ} \mathrm{C}$ por 1 hora sob constante agitação de forma que todas as esferas ficassem imersas nesta solução. Foram realizadas três lavagens do poliestireno expandido com água destilada e deionizada para a eliminação do excesso do glutaraldeído.

As esferas de isopor tratadas foram mergulhadas na suspensão enzimática por $24 \mathrm{~h}$ a $30^{\circ} \mathrm{C}$ sob constante agitação para a imobilização da enzima no isopor através das ligações eletrostáticas e por ligações covalentes com o glutaraldeido fixado ao isopor.

A imobilização em poliestireno colapsado foi realizada conforme Prabhu \& Chandrasekaran (1997). O isopor foi submetido a uma autoclavagem $\left(121^{\circ} \mathrm{C}\right)$ por 15 minutos, de forma que seu tamanho foi reduzido a aproximadamente $1 / 3$ de seu tamanho original e sua densidade aumentada possibilitando sua imersão no liquido e a obtenção do peso desejado com um menor volume de trabalho. Com isso tornou-se mais fácil o seu manuseio, uma vez que se tratava de uma matriz que não necessitava ficar sob espaço reduzido para que ficasse imersa no líquido aumentando assim o contato da enzima com o substrato.

\subsection{Imobilização da enzima em nylon $6^{(1)}$}

Limalhas de nylon ${ }^{\circledR} 6$ retiradas de uma barra cilíndrica em um torno mecânico foram picadas em pequenos pedaços obtendo-se uma maior superficie de reação. $O$ nylon ${ }^{\circledR}$ foi submetido a uma hidrólise com $\mathrm{HCl}$ a $2,9 \mathrm{M}(1: 3)$ por $2 \mathrm{~h}$ a $37^{\circ} \mathrm{C}$. Em seguida, realizou-se uma lavagem com água deionizada e depois em tampão fosfato pH 8.0.

Adicionou-se glutaraldeído a $2,5 \%$ em tampão fosfato $\mathrm{pH} 8.0$ deixando-se incubar por no mínimo 15 minutos a temperatura de $20^{\circ} \mathrm{C}$. 
Após lavagem com água e tampão fosfato $\mathrm{pH} 8.0$, incubou-se o sobrenadante pré-purificado na matriz preparada, de náilon-glutaraldeído, a $4^{\circ} \mathrm{C}$ durante um período de no mínimo $15 \mathrm{~h}$

A enzima imobilizada então era lavada e usada nos ensaios de atividade.

\subsection{Imobilização em copolímero alginato-gel-quitosana}

\subsubsection{Preparo da quitosana}

A quitosana foi preparada por $\mathrm{N}$-deacetilação da quitina de lagosta em meio alcalino (Albarghouthi et al., 2000) conforme procedimento abaixo.

A quitina foi colocada em uma solução de $\mathrm{NaOH} 50 \%$ (peso/volume) e aquecida a $110^{\circ} \mathrm{C}$ por 1 hora (processo de deacetilação da quitina).

Após esse período, a solução foi filtrada em papel de filtro para a retirada do hidróxido de sódio, seguindo-se de uma lavagem com água destilada. Esta lavagem foi realizada até que o valor de $\mathrm{pH}$ fosse reduzido para o valor de $\mathrm{pH}$ inicial da água destilada. A quitina, já transformada em quitosana, pelo menos $70 \%$ do montante inicial de quitina (Mima, 1983), foi liofilizada até que apresentasse a textura de um pó fino.

A quitosana foi peneirada à porosidade de 80 mesh e acondicionada em um frasco à temperatura ambiente para a posterior utilização.

\subsubsection{Preparo do copolímero}

Foram utilizados para o preparo: o alginato de sódio a $1 \%$ (solução para o gotejamento contendo: $\mathrm{CaCl}_{2} \bullet \mathrm{H}_{2} \mathrm{O}$ na concentração $14,7 \mathrm{~g} \times \mathrm{L}^{-1}$, quitosana peneirada a 0,5\% e ácido acético a $0,5 \%$ (para a solução de copolimerização)).

Para o preparo da solução para copolimerização, preparou-se uma solução estoque de gel quitosana. Para tanto acrescentou-se $0,5 \%$ de ácido acético, que atua como solvente da quitosana (Huang et al., 2000). O cloreto de cálcio só foi adicionado na hora do preparo das esferas. 
A solução de alginato de sódio foi adicionada à solução para polimerização utilizando-se bomba peristáltica e sob agitação de maneira a serem formadas pequenas esferas até que se esgotasse todo o volume de alginato preparado na proporção máxima de uma parte de solução alginato para duas de solução de copolimerização. Após a formação das esferas estas permaneciam durante a noite em geladeira para que o cálcio estabilizasse a estrutura do copolímero. Então as esferas eram lavadas com água destilada com no mínimo quatro enxágües para a remoção do excesso de solução de copolimerização e depois secas em papel filtro.

\subsubsection{Imobilização da enzima por ligações covalentes}

Para a ligação covalente foi necessária a ativação das esferas com glutaraldeído. As esferas foram pesadas ( $500 \mathrm{mg}$ de esferas secas) e colocadas em $2 \mathrm{~mL}$ de tampão borato $\mathrm{pH} 7,2$ contendo $5 \mathrm{mM}$ de $\mathrm{CaCl}_{2}$ e $0,25 \%$ de glutaraldeído $(\mathrm{p} / \mathrm{v})$, sob agitação por 60 minutos.

As esferas foram lavadas quatro vezes com o tampão borato contendo $5 \mathrm{mM}$ de $\mathrm{CaCl}_{2}$ para a remoção do excesso de glutaraldeído. As esferas foram secas em papel filtro.

As esferas ativadas foram colocadas no sobrenadante de Kluyveromyces marxianus MMIl-41 pré-purificado na concentração protéica aproximada de $100 \mu \mathrm{g} / \mathrm{mL}$, durante toda a noite. Quando deixadas mais de 24 horas, as enzimas em suspensão atacavam o gel-quitosana desfazendo o copolímero. Logo após o tempo de imobilização, as esferas foram lavadas com o tampão borato, $\mathrm{pH} 7,2$ contendo $5 \mathrm{mM}$ de $\mathrm{CaCl}_{2}$, e mantidas neste tampão sob refrigeração até a hora do uso.

\subsubsection{Imobilização da enzima por aprisionamento}

A imobilização da enzima no copolímero alginato-gel-quitosana por aprisionamento foi realizada na formação do mesmo. O sobrenadante de Kluyveromyces marxianus $\mathrm{MMII}-41$ foi misturado ao alginato dissolvido a $2 \%$ em tampão fosfato $\mathrm{pH}$ 
7.0 para formar a solução de gotejamento com $1 \%$ de alginato de sódio e com a concentração final de proteína com metade da concentração inicial do sobrenadante, seguindo o procedimento do item 4.12.2. Após a formação das esferas contendo a enzima, essas eram mantidas por 15 horas em tampão fosfato $\mathrm{pH} 7.0$ contendo $0,25 \%$ de glutaraldeido de forma a manter as esferas mais estáveis e assegurar uma melhor fixação das enzimas.

\subsection{Ensaio comparativo em sistema batelada}

Foram realizados ensaios de atividade comparativa da enzima em tubos de ensaio mantidos a $38^{\circ} \mathrm{C}$ por imersão em banho-maria. Comparou-se o sobrenadante de Kluyveromyces marxianus MMIII-41, o material imobilizado e o sobrenadante restante, sempre utilizando $1 \mathrm{~g}$ ou $1 \mathrm{~mL}$ (dependendo da matriz) frente a $2 \mathrm{~mL}$ de extrato de Helianthus tuberosus desproteinizado com 17 graus brix. Os resultados foram expressos em porcentagem de açúcares redutores (AR) formados em relação ao montante de AR formado pela reação com o sobrenadante original. $\mathrm{O}$ branco foi elaborado com a mesma proporção de enzima frente ao substrato, porém com a enzima desnaturada a $100^{\circ} \mathrm{C}$ por 5 minutos conforme realizado por Rikir et al. (1990). O mesmo extrato foi utilizado como branco para o desconto do valor dos açúcares redutores já presentes no substrato de forma a ser medido apenas o AR formado por processo enzimático. Todas as amostras retiradas foram fervidas por cinco minutos para a total inativação da enzima.

\subsection{Determinação da correlação entre as atividades enzimáticas nos diferentes substratos}

Os ensaios enzimáticos foram realizados em tubos de ensaio marca Pyrex ${ }^{(1)}$ de $15 \mathrm{~cm}$ de altura por $2,5 \mathrm{~cm}$ de diâmetro, utilizando-se sacarose, pectina e inulina como substrato. Os tubos foram mergulhados parcialmente em um banho térmico à temperatura de $38^{\circ} \mathrm{C}$. Primeiramente foram realizados ensaios para a determinação da melhor relação concentração enzimática e concentração de substrato para a obtenção de uma curva que permitisse a visualização da fase linear da cinética enzimática de forma a 
poder ser determinada a velocidade máxima de reação. Foram definidas as concentrações de $1 \%$ para todos os substratos e as concentrações de proteína de $0,4135 \mathrm{mg} \mathrm{x} \mathrm{mL}^{-1}$ para o substrato inulina e $0,0165 \mathrm{mg} \mathrm{x} \mathrm{mL}^{-1}$ para sacarose e pectina.

A amostragem foi feita a cada 15 minutos até o tempo de 375 minutos, o que permitiu uma boa visualização da cinética da enzima. Os ensaios foram repetidos três vezes.

Os resultados foram registrados em gráficos para a determinação da fase linear e posterior elaboração das regressões lineares que determinariam a velocidade de reação.

Para a elaboração dos gráficos mostrados neste trabalho foi determinada uma unidade $U$, que significa \% de açúcares redutores formados $\mathrm{X}$ mg de proteína ${ }^{-1}$.

Com esses dados foram construidos dois gráficos que correlacionam as curvas de atividade enzimática na fase linear coincidente entre os substratos sacarose e pectina e sacarose e inulina. O objetivo desta correlação foi determinar um fator de conversão que permitisse calcular de forma aproximada a atividade nos substratos inulina e pectina à partir de ensaios realizados com sacarose. Isso foi necessário devido à diferença de preços e facilidade de obtenção desse substrato em relação aos substratos aos quais se pretenderia aplicar a enzima em um processo industrial. Portanto seria uma extrapolação viável passível de pequenos ajustes no desenvolvimento de um processo industrial.

\subsection{Ensaio preliminar para a determinação de atividade hidrolítica máxima com as diferentes matrizes}

As diferentes matrizes devidamente preparadas foram submetidas a ensaios, frente ao substrato sacarose a $5 \%$ em um sistema de recirculação (sistema descontínuo), com o objetivo de se determinar a cinética enzimática através da determinação do produto acumulado no sobrenadante pelo método de Somogyi e Nelson (Somogyi, 1945). Todas as amostras retiradas foram imediatamente fervidas por cinco minutos para a inativação da enzima para evitar que, caso tenha havido algum desprendimento, se formem açúcares redutores na amostra dando um falso valor. Os dados foram registrados em um gráfico de dispersão obtendo-se, a partir da regressão linear da fase exponencial, 
a inclinação da reta. Este ensaio objetivou a determinação da melhor matriz para a imobilização desta enzima.

\subsection{Ajustes da simulação de um processo industrial com a enzima imobilizada}

Após a determinação da melhor matriz para a imobilização da enzima foram realizados ensaios contra uma solução de sacarose a $5 \%$ determinando-se o tempo de permanência necessário para a total degradação do substrato em um processo com fluxo contínuo.

\subsection{Ensaios de estabilidade}

Com a determinação do parâmetro de fluxo para a total degradação do substrato frente a matriz escolhida foram realizados ensaios de fluxo contínuo que determinaram a queda da atividade enzimática no decorrer do tempo para se definir o tempo de vida útil do imobilizado, visando determinar a capacidade de reaproveitamento. Como controle foi deixado um frasco contendo o sobrenadante de Kluyveromyces marxianus MMIII-41 (o mesmo utilizado na imobilização) sob a mesma temperatura do processo e simultaneamente às amostragens, foram realizados ensaios de atividade enzimática. $\mathrm{O}$ objetivo deste controle foi determinar se a possível queda de atividade no processo seria conseqüência da queda da atividade enzimática ou simplesmente do desprendimento da enzima da matriz. Como conseqüência deste controle obteve-se uma curva que demonstrou a queda da atividade do sobrenadante de Kluyveromyces marxianus MMIII41 no decorrer do tempo. 


\section{RESULTADOS E DISCUSSÃo}

\subsection{Atividade de extratos enzimáticos}

Com a intenção de se caracterizar melhor as enzimas produzidas pela levedura $K$. marxianus, foi realizado um ensaio visando determinar os tipos de ligações que essas enzimas quebram, e para tanto foram testados diferentes açúcares.

Supunha-se em trabalhos anteriores realizados no Laboratório de Genética de Leveduras da ESALQ/USP que havia uma única enzima bifuncional responsável pelas atividades de inulinase e pectinase (Pereira, 1989), já que o sobrenadante de $K$. marxianus apresentava ambas atividades, invertase e inulinase. De fato, observou-se em um ensaio realizado in loco, que uma única banda eletroforética apresentava atividade enzimática para a inulina e pectina.

Este aspecto de bi-funcionalidade do sobrenadante de $K$. marxiantus MMIII-41, e o fato de terem sido citados por outros autores a presença, em Kluyveromyces marxianus, de endopoligalacturonase (E.C. 3.2.1.15) e exopoligalacturonase (E.C. 3.2.1.67) (Sanchez, 1984) e a inulinase E.C. 3.2.1.7 (Cruz-Guerrero, 1995), nos levou a pensar em pelo menos duas diferentes enzimas. Os estudos realizados anteriormente no laboratório de genética de leveduras da ESALQ/USP sugeriram a presença de uma única enzima (Pereira, 1989). O gel de poliacrilamida com SDS apresentou uma banda eletroforética na faixa próxima a $97 \mathrm{kDa}$ (Figura 10), porém os ensaios de eletroforese não desnaturante resultaram em géis com apenas duas bandas eletroforéticas muito próximas mesmo em gel 15\% (Figura 11). No corte e eluição dessas bandas, ambas apresentaram atividades de inulinase, pectinase e invertase, porém não se pode afirmar 
com certeza se essas atividades são de uma ou de ambas bandas, pois pode estar havendo contaminação entre elas.

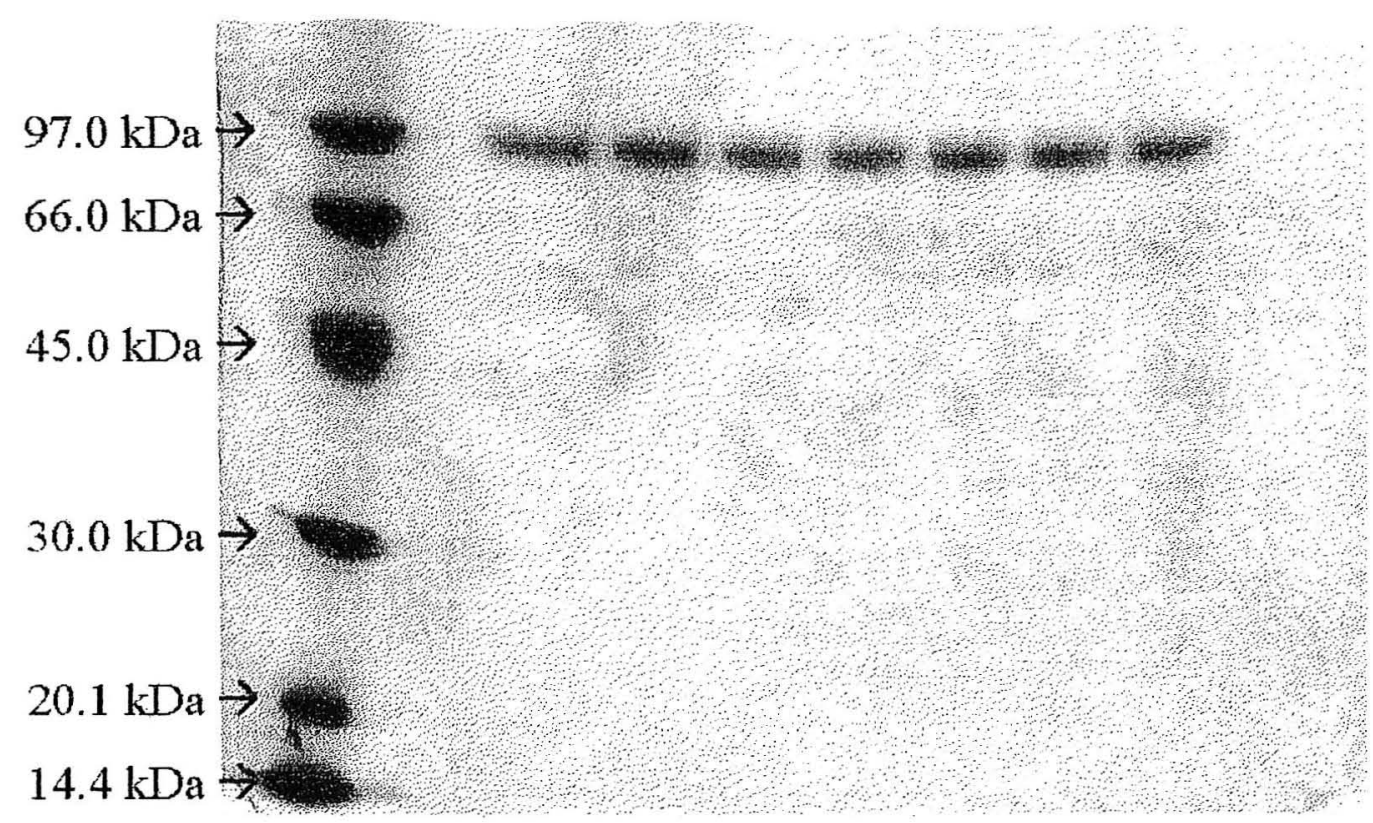

Figura 10 - Gel de poliacrilamida com SDS corado por "Coomassie Blue" mostrando uma banda de aproximadamente $97 \mathrm{kDa}$ presente no sobrenadante não purificado de Kluyveromyces marxianus MMIII-41 


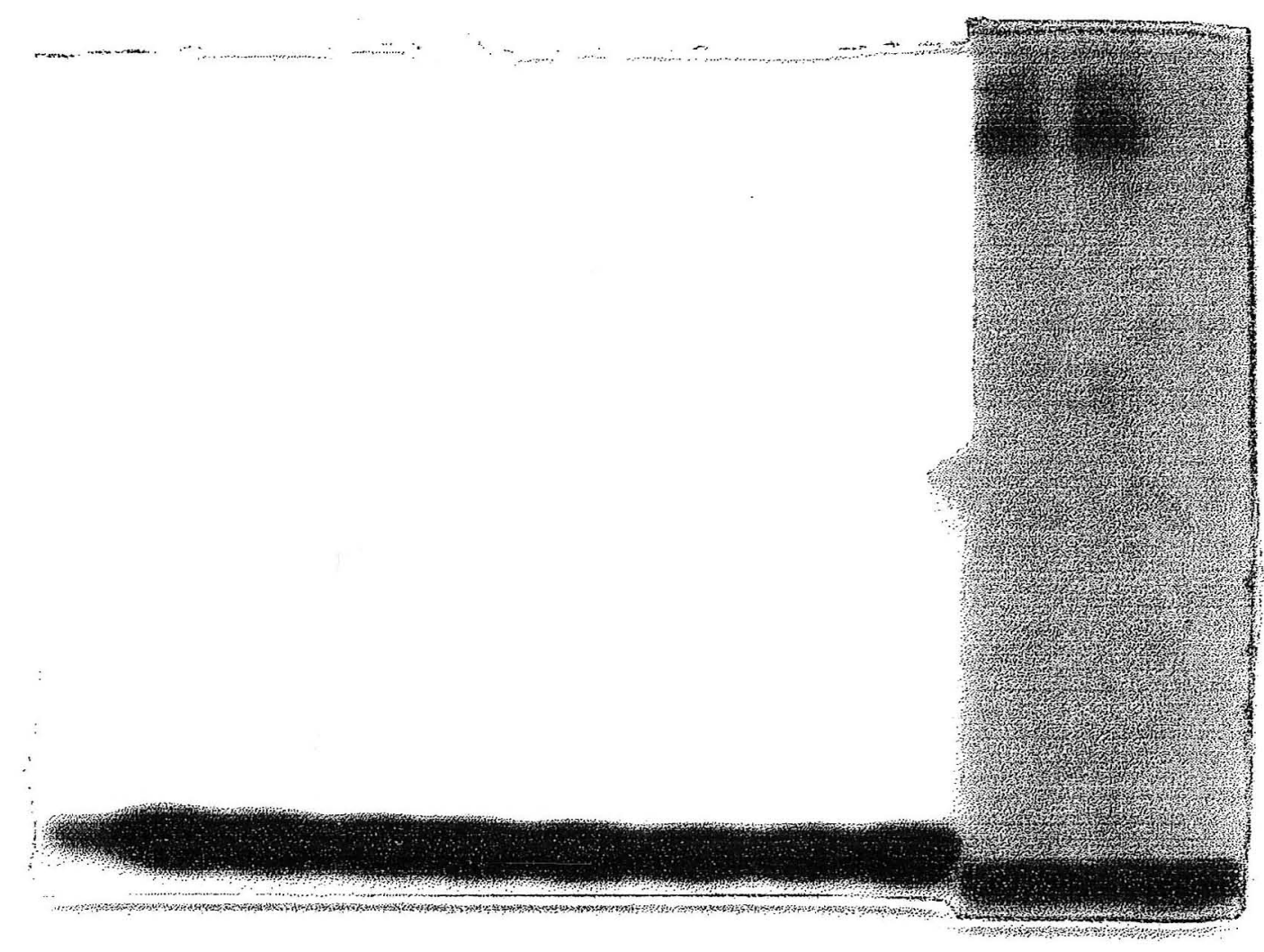

Figura 11 - Gel de eletroforese não desnaturante corado por "Coomassie Blue" mostrando as duas bandas presentes no sobrenadante não purificado de Kluyveromyces marxianus MMII-41

Os resultados do ensaio com outros açúcares demonstraram que o sobrenadante desta levedura apresenta atividade sobre amido, dextrana e D-melezitose (Figura 12) indicando que existem enzimas que quebram ligações do tipo $\alpha-1,4$ do amido, da dextrana e da pectina, bem como ligações do tipo $\beta-2,1$ presentes na inulina. Outros autores também relataram atividade da inulinase sobre outros açúcares como a sacarose (Gaspari, 1998; Wenling et al., 1999; Ettalibi \& Baratti, 2001) e a rafinose (Cruz et al., 1998). 


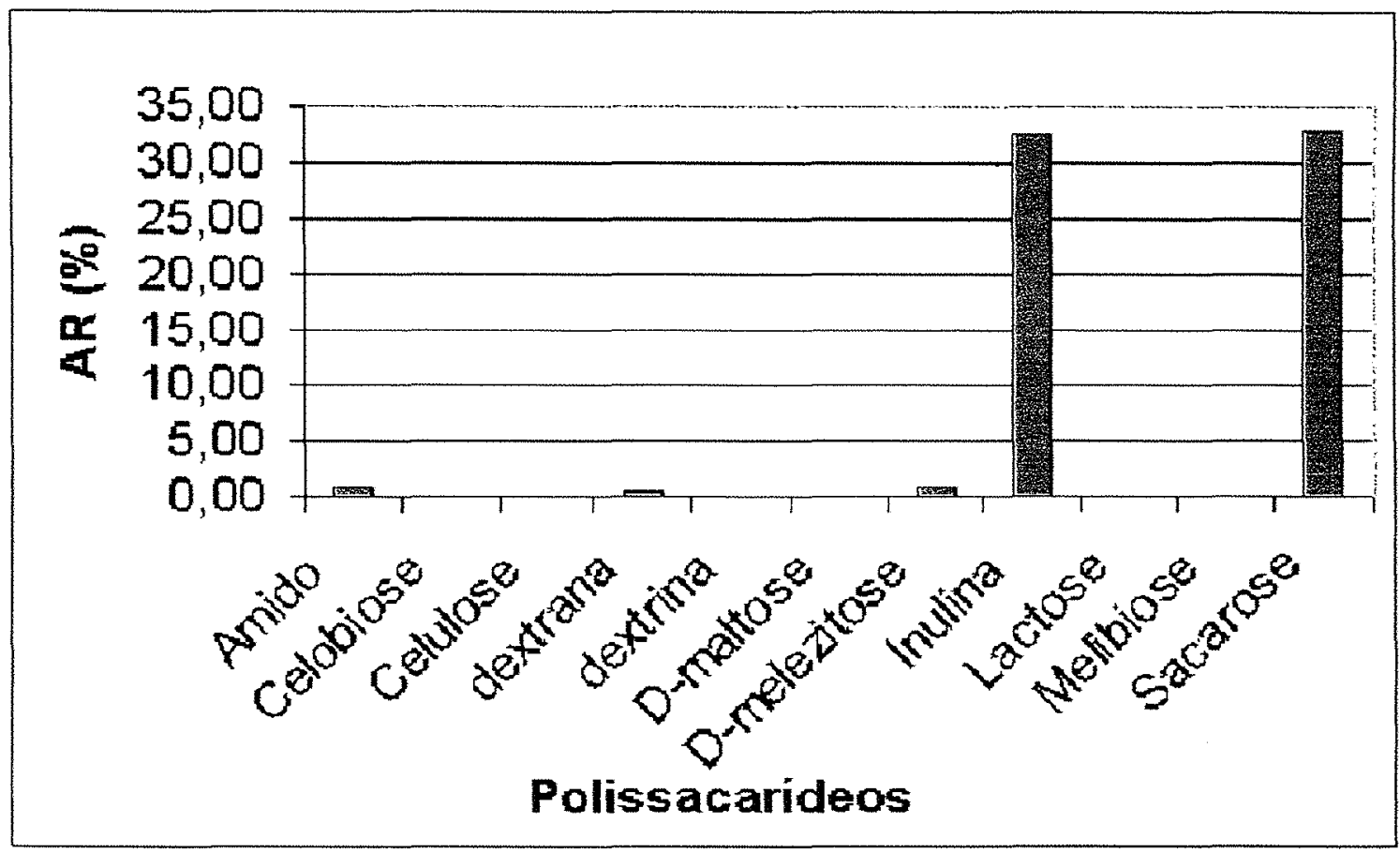

Figura 12 - Açúcares redutores formados a partir dos substratos, amido, celobiose, celulose, dextrana, dextrina, D-maltose, D-melezitose, inulina, lactose, melibiose e sacarose

Para uma melhor caracterização das enzimas produzidas pela $K$. marxianus MMII-41, foram realizadas determinações de pHs e temperaturas ótimas para a enzima. Estes ensaios demonstraram a sua grande versatilidade já que as atividades permanecem estáveis de 30 a $50^{\circ} \mathrm{C}$ dependendo do substrato e do $\mathrm{pH}$ utilizado, sendo mais ativas a pHs ácidos (nos três substratos) e menos ativa em pHs mais alcalinos (Figuras 13, 14 e 15). Para os ensaios realizados com sacarose como substrato, as maiores atividades foram observadas nas temperaturas de 30 e $40^{\circ} \mathrm{C}$. A $30^{\circ} \mathrm{C}$ a queda de atividade foi maior em pH acima de 7,0 , em temperaturas mais extremas, a queda já foi observada no $\mathrm{pH}$ 6,0. Quando em temperaturas de 40 e $50^{\circ} \mathrm{C}$, a atividade se manteve mais estável em valores de $\mathrm{pH}$ mais altos (alcalinos). Portanto, para substratos que apresentem valores de pH mais alcalinos é melhor que se trabalhe nestas temperaturas. Porém, como a grande maioria dos substratos de interesse é mais ácida (sucos e extrato de Helianthus 
tuberosus), deve-se dar preferência a temperaturas entre 30 e $40^{\circ} \mathrm{C}$. Os dados obtidos com sacarose mostraram-se similares aos dados obtidos por Pereira 1989 com inulina e pectina, no que se refere à temperatura ideal, de 30 a $40^{\circ} \mathrm{C}$. Quanto ao $\mathrm{pH}$, Pereira determinou como melhor o pH 6,5. Nos resultados observados na Figura 12 isso só é aparentemente verdade para a temperatura de $40^{\circ} \mathrm{C}$. A $30^{\circ} \mathrm{C}$ a atividade tende a ser melhor em valores de $\mathrm{pH}$ mais próximos de 4,0 , porém nesta temperatura não se pode afirmar que as atividades entre $\mathrm{pH} 4.0$ e 6.0 sejam diferentes.

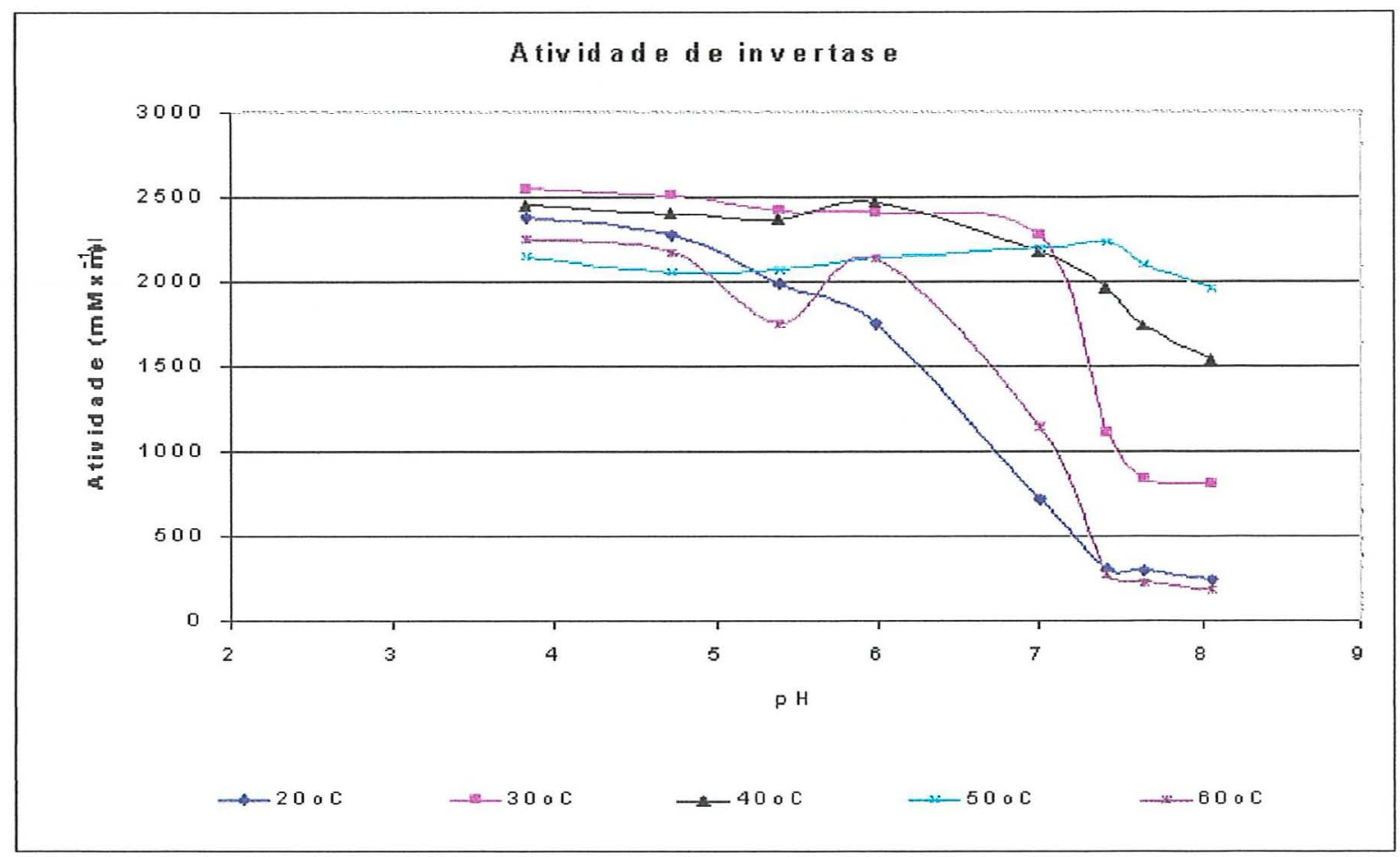

Figura 13 - Atividade de invertase em diferentes temperaturas e valores de $\mathrm{pH}$. Em azul escuro vemos a curva de diferentes valores de $\mathrm{pH}$ a $20^{\circ} \mathrm{C}$, em rosa a $30^{\circ} \mathrm{C}$, em preto $40^{\circ} \mathrm{C}$, em azul claro $50^{\circ} \mathrm{C}$ e em vinho $60^{\circ} \mathrm{C}$

Quando o substrato é a inulina, as melhores temperaturas estão entre 40 e $60^{\circ} \mathrm{C}$ e o melhor valor de $\mathrm{pH}$ encontrado foi aproximadamente em torno de 5,0 (Figura 14) resultados estes, que concordam com os observados por Byun \& Nahm (1978), que

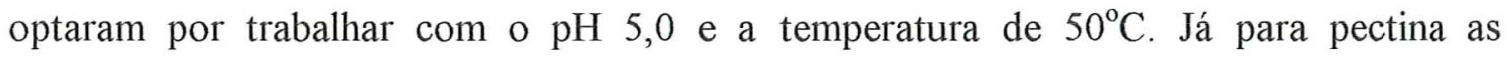
melhores temperaturas estão entre 30 e $40^{\circ} \mathrm{C}$ mantendo a tendência de melhores 
atividades em valores de $\mathrm{pH}$ menores, porém com boa atividade até o valor de $\mathrm{pH}$ 7,0, dependendo da temperatura (Figura 15).

Cabe ressaltar que as atividades de pectinase e invertase apresentam curvas de atividade mais similares do que as observadas com inulina. Assim sendo fica mais dificil estabelecer uma relação entre invertase e pectinase com a inulinase. Portanto, para ser possível qualquer relação entre as atividades, seria necessário se trabalhar com valores de $\mathrm{pH}$ próximos de 5,0 .

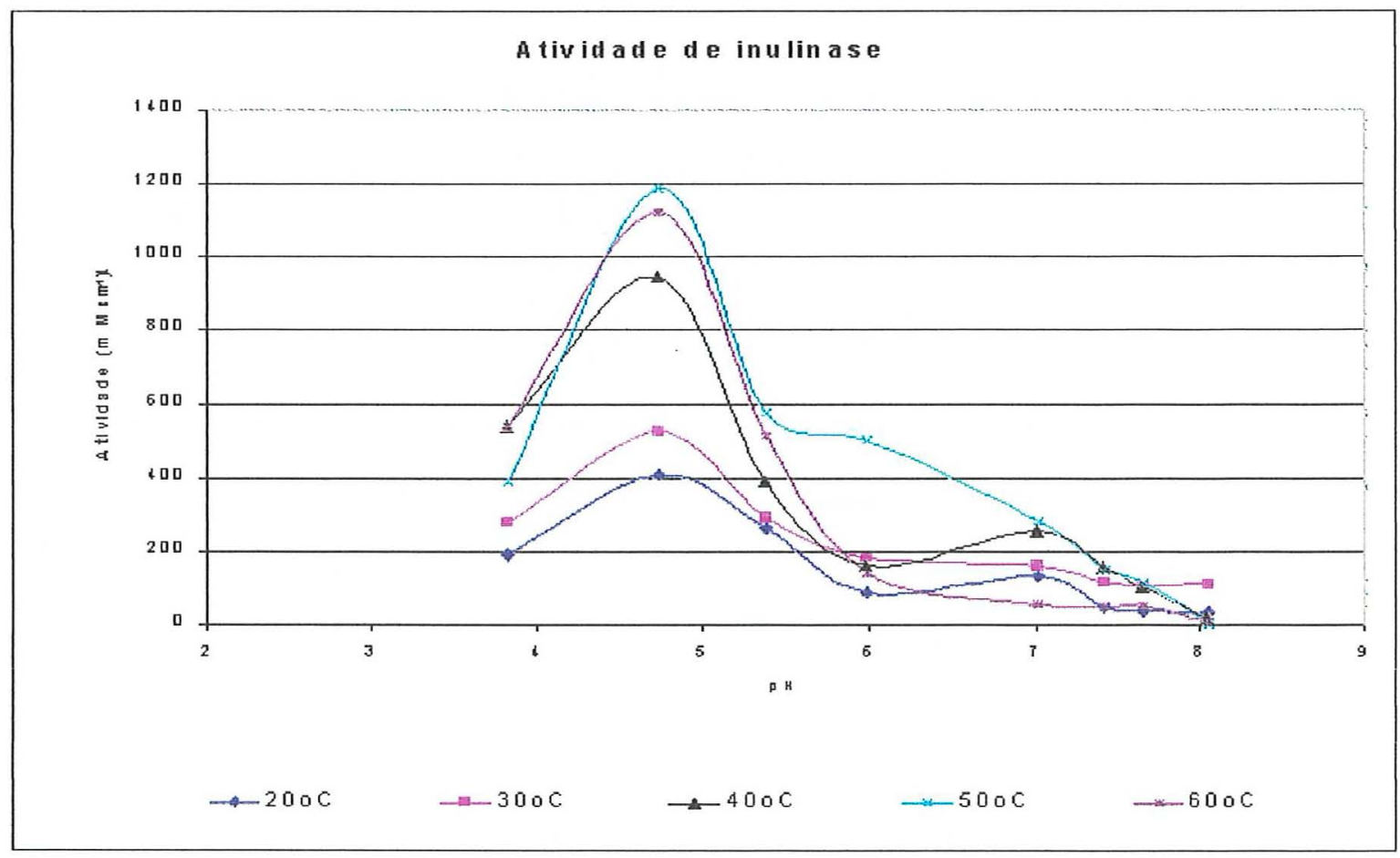

Figura 14 - Atividade de inulinase em diferentes temperaturas e valores de $\mathrm{pH}$. Em azul escuro vemos a curva de diferentes valores de $\mathrm{pH}$ a $20^{\circ} \mathrm{C}$, em rosa a $30^{\circ} \mathrm{C}$, em preto $40^{\circ} \mathrm{C}$, em azul claro $50^{\circ} \mathrm{C}$ e em vinho $60^{\circ} \mathrm{C}$ 


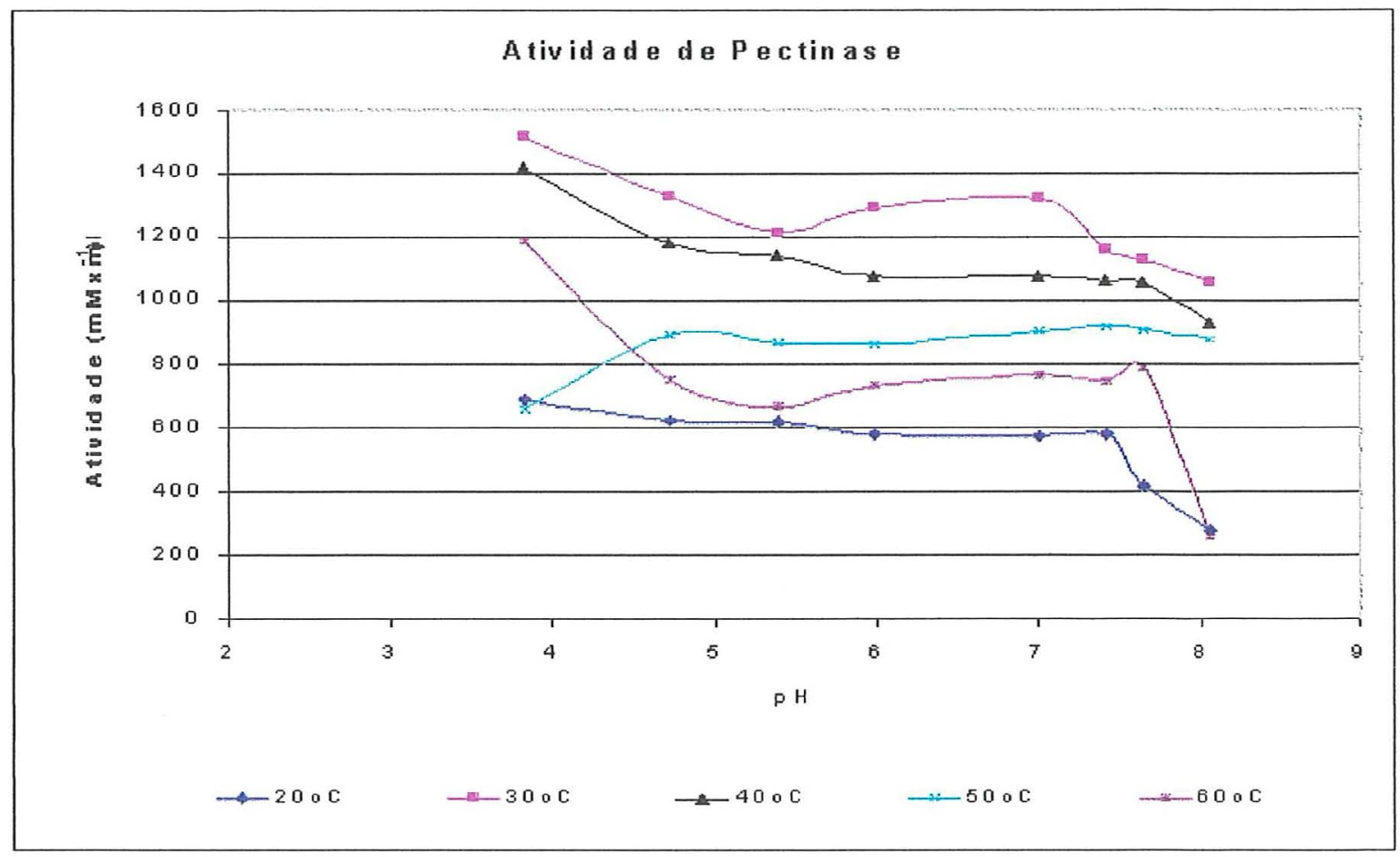

Figura 15 - Atividade de pectinase em diferentes temperaturas e valores de pH. Em azul escuro vemos a curva de diferentes valores de $\mathrm{pH}$ a $20^{\circ} \mathrm{C}$, em rosa a $30^{\circ} \mathrm{C}$, em preto $40^{\circ} \mathrm{C}$, em azul claro $50^{\circ} \mathrm{C}$ e em vinho $60^{\circ} \mathrm{C}$

\subsection{Atividade pectinolítica extracelular}

Visando demonstrar a atividade pectinolítica extracelular de Kluyveromyces marxiamus foi realizado um experimento em placa de petri com meio de cultura contendo extrato de levedura, peptona, pectina como fonte de carbono e vermelho congo como marcador de $\mathrm{pH}$. Como padrão negativo foi utilizado Saccharomyces cerevisiae (Fleischmann). A quebra da pectina forma ácido galacturônico, que pode ser visualizado pelo halo formado em torno da linhagem produtora de pectinase (Figura 16). 


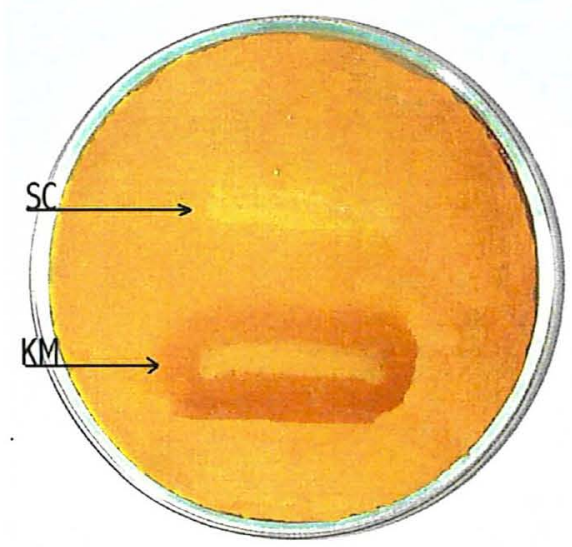

Figura 16 - Formação de halo aparente pelo $\mathrm{pH}$ de viragem do vermelho gongo decorrente da formação de ácido galacturônico SC = Saccharomyces cerevisiae Fleischmann; KM = Kluyveromyces marxianus MMIII-41

\subsection{Purificação das enzimas.}

Para uma melhor caracterização das enzimas foram realizados experimentos de precipitação por sulfato de amônio visando determinar a concentração necessária para se precipitar as proteínas de interesse.

Os resultados demonstraram que a purificação por precipitação por sulfato de amônio se mostrou eficiente uma vez que na faixa de saturação de $70 \%$ de sulfato de amônio há precipitação de uma quantidade grande de proteínas. A atividade da enzima se concentra na faixa de saturação entre 70 a $90 \%$ e acima de $90 \%$, o que permite uma razoável diminuição das impurezas do sobrenadante de Kluyveromyces marxianus MMIII-41 (Figura 17). 


\section{Precipitação por sulfato de amônio}

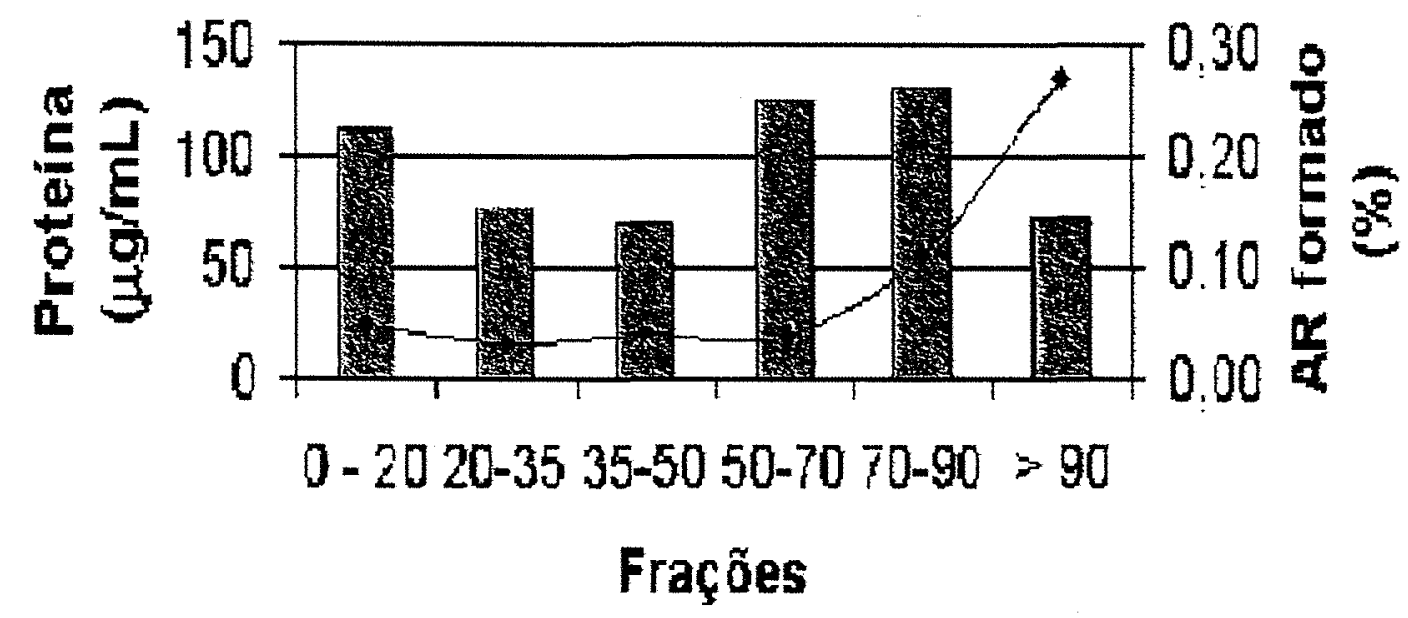

Figura 17 - Gráfico demonstrando a concentração de proteina de cada fração (Barras) e a atividade da enzima nas frações através de quantificação de açúcares redutores formados (linha e losangos)

\subsection{Atividade enzimática das enzimas livres e respectiva cinética}

Este experimento comparou a produção de açúcares redutores formados por $\mathrm{mg}$ de proteína nos substratos, sacarose, inulina e pectina relacionando-se os dois últimos ao primeiro pelo método de correlação descrito em Paz (1997).

As Figuras 18 a 20 mostram a fase linear da cinética enzimática com os substratos pectina, inulina e sacarose, respectivamente. As Figuras 21 e 22 mostram correlação entre sacarose e pectina e entre sacarose e inulina. Essa conversão se dá a partir da regressão linear que gera as equações $y=2,6124 x+0,193$, para a conversão em pectina e $y=0,1659 x+0,0696$ para a conversão em inulina, onde " $y$ " representa o valor de pectina ou inulina para um valor " $x$ " de sacarose (Paz, 1997). A cinética enzimática é mostrada na Figura 21. 


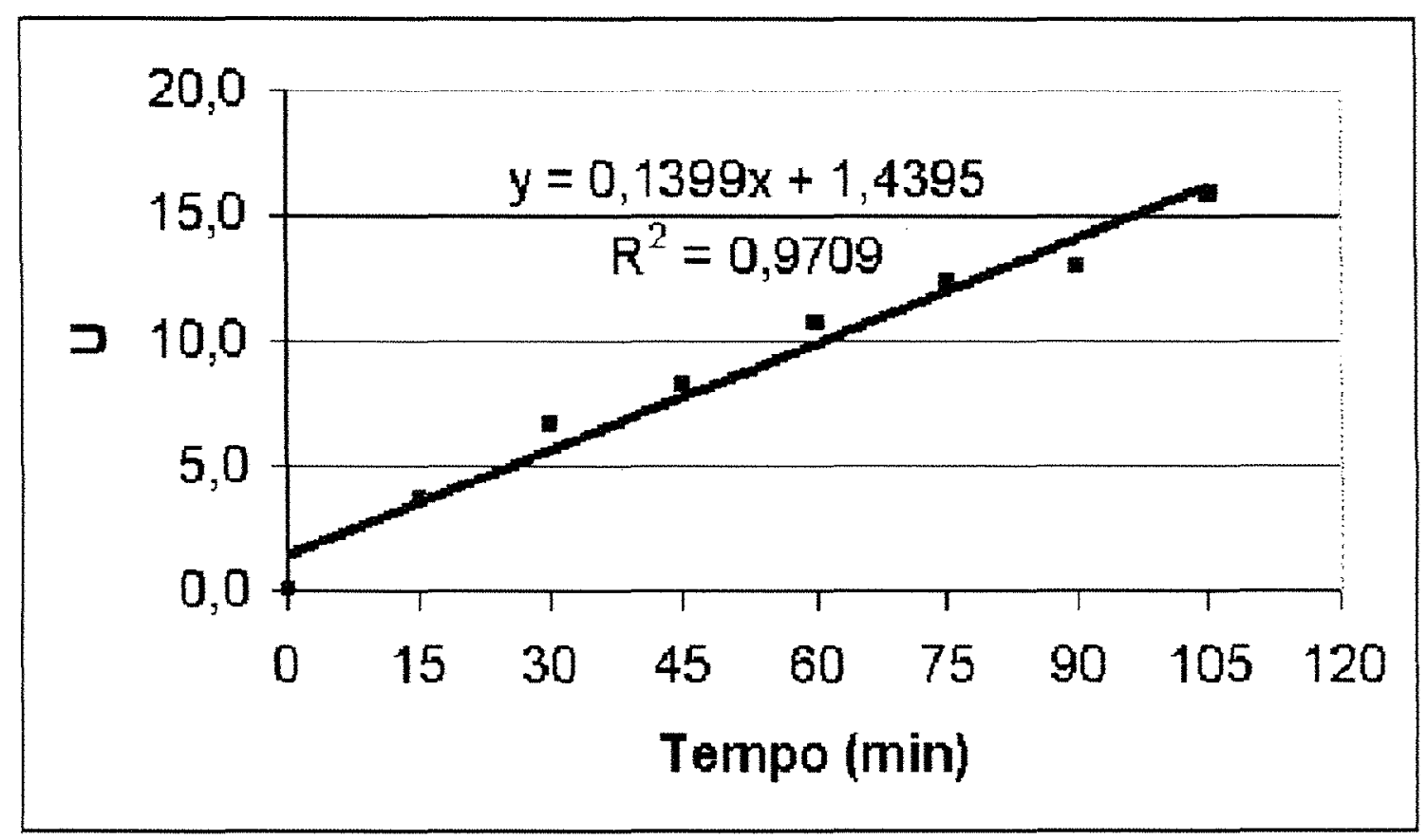

Figura 18 - Gráfico de unidades de atividade enzimática $\left(U=A R \% x\left(\mu g \text { prot.xmL }{ }^{-1}\right)^{-1}\right)$ a partir da pectina, em função do tempo em minutos 


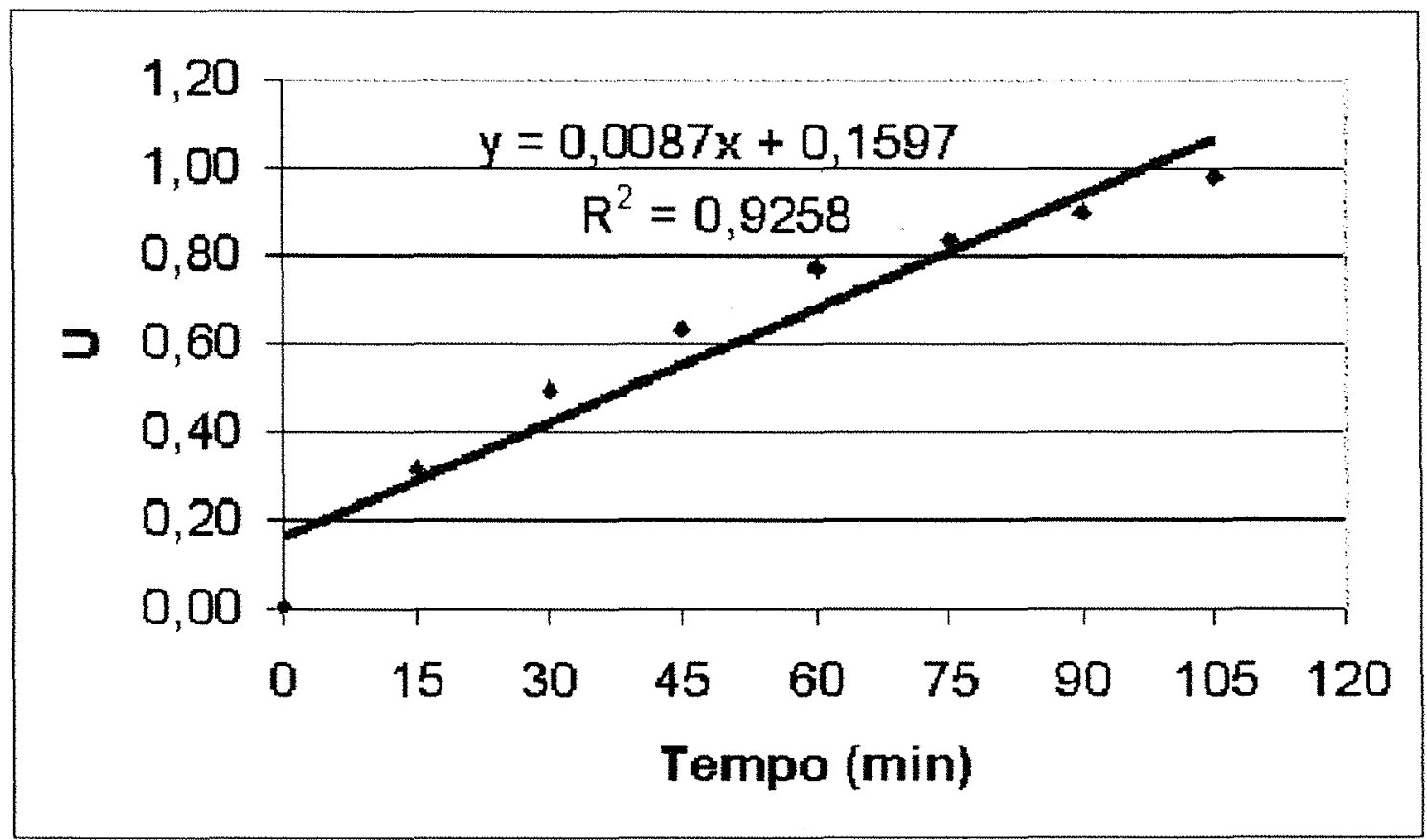

Figura 19 - Gráfico de unidades atividade enzimática $\left(U=A R \% x\left(\mu g \text { prot.xmL }{ }^{-1}\right)^{-1}\right)$ a partir da inulina, em função do tempo em minutos 


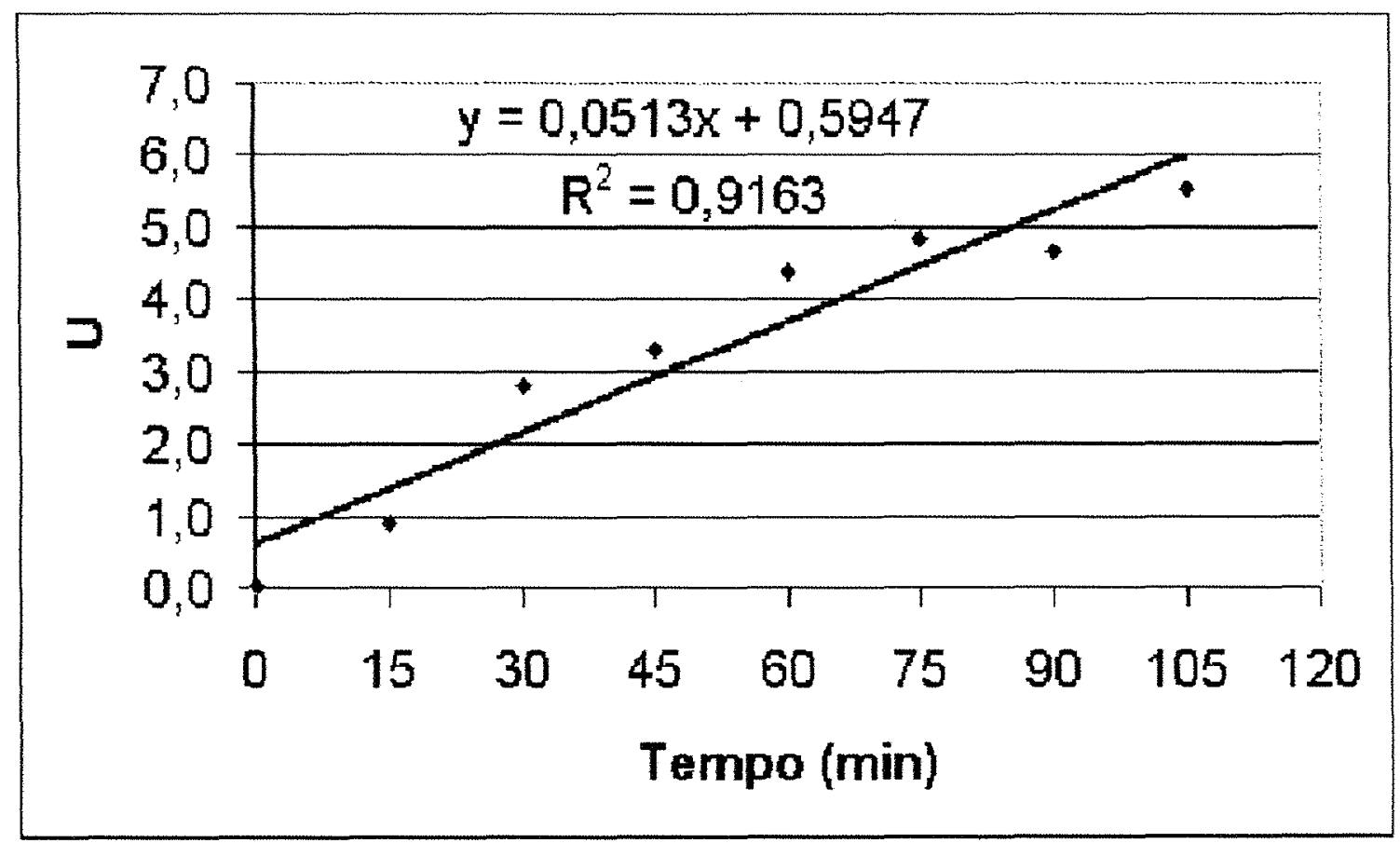

Figura 20 - Gráfico de unidades de atividade enzimática $\left(U=A R \% x\left(\mu g \text { prot.xmL }{ }^{-1}\right)^{-1}\right) a$ partir da sacarose, em função do tempo em minutos 


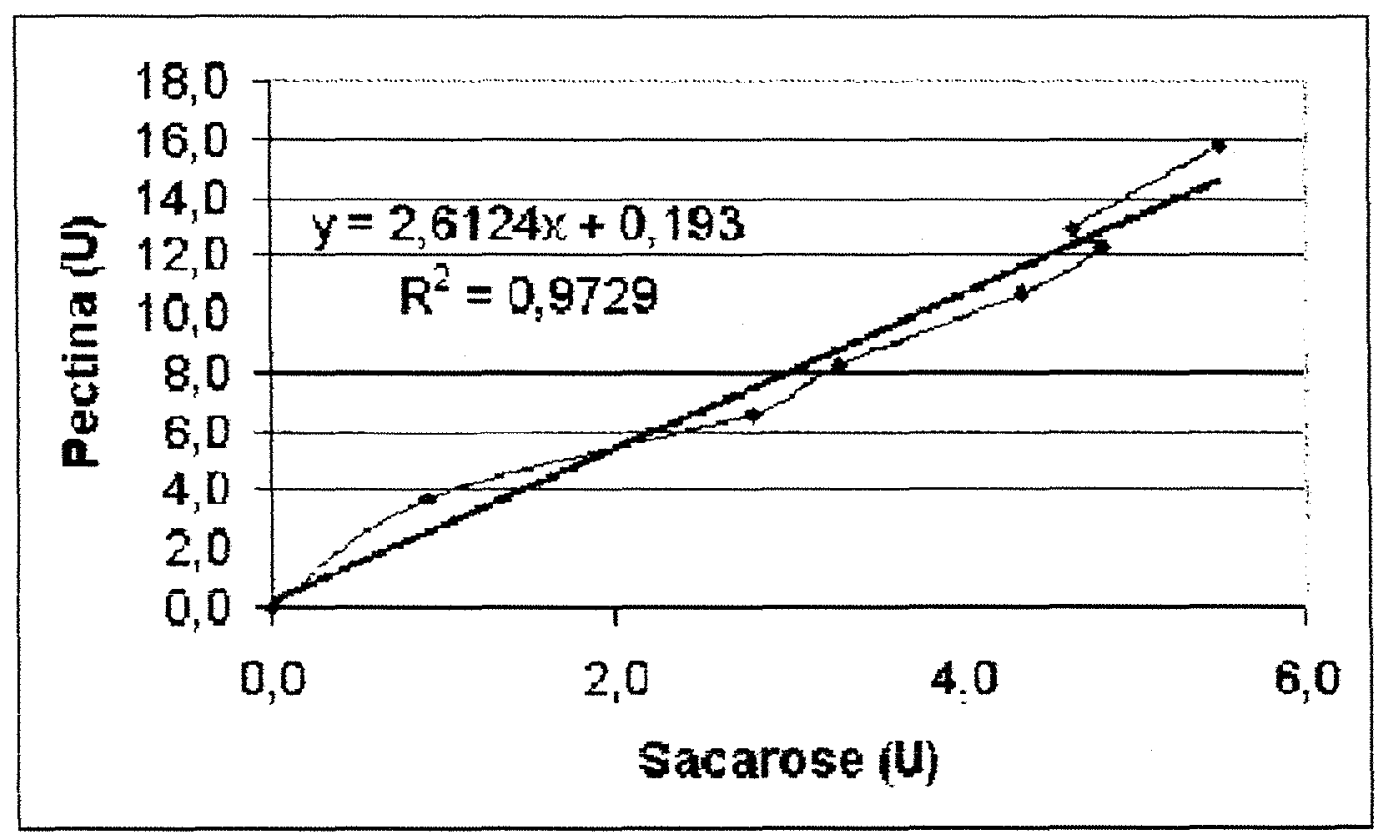

Figura 21 - Gráfico de unidades de sacarose em relação a unidades de pectina ( $U=$ $\left.\mathrm{AR} \% \mathrm{x}\left(\mu \mathrm{g} \text { prot. } x \mathrm{~mL}^{-1}\right)^{-1}\right)$, geradas na fase exponencial da cinética enzimática, realizada sob mesmas condições. A equação é resultado da regressão linear que permite a conversão de sacarose à pectina 


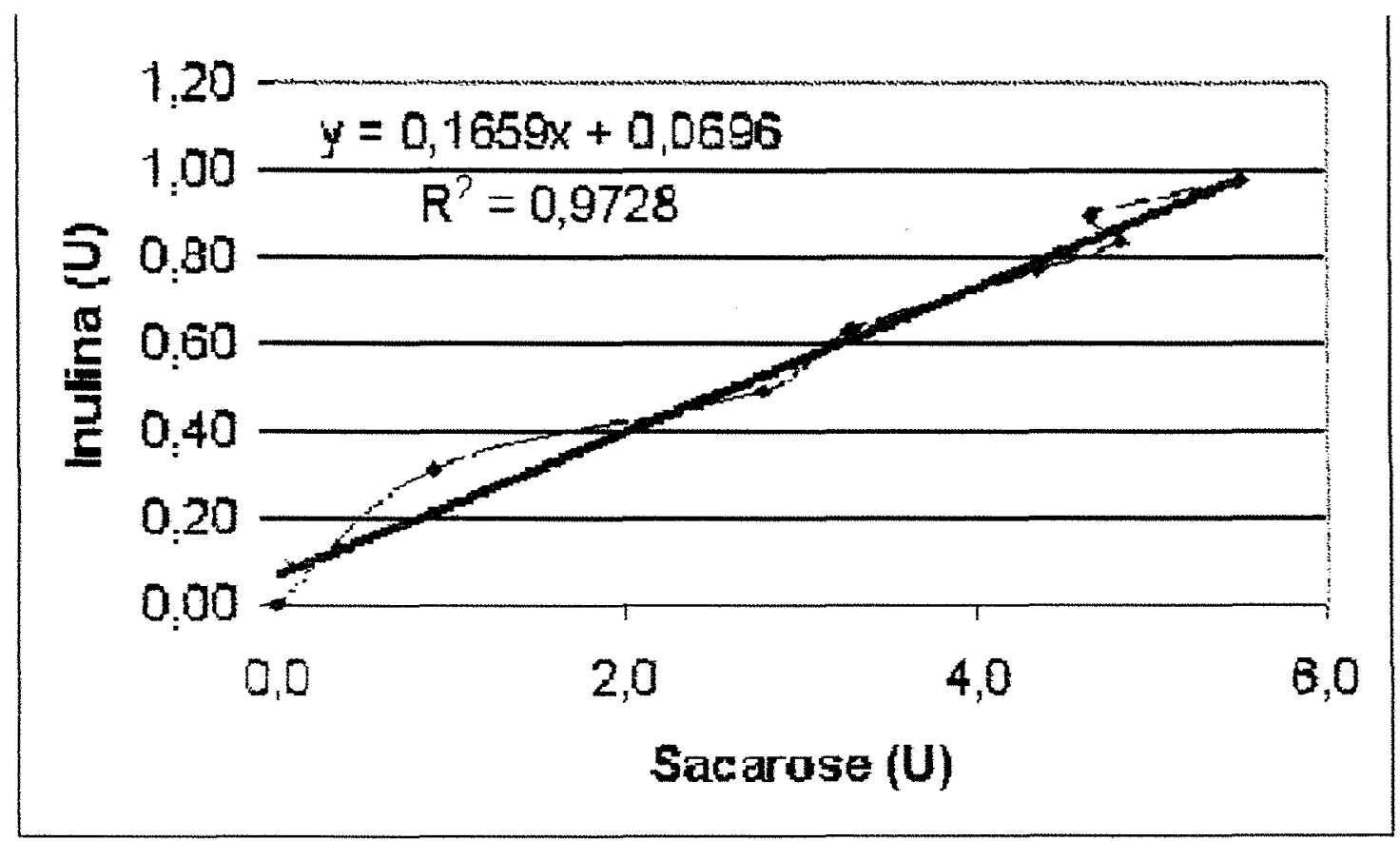

Figura 22 - Gráfico de unidades de sacarose em relação a unidades de inulina ( $U$ = $\left.\mathrm{AR} \% \mathrm{x}\left(\mu \mathrm{g} \text { prot. } x \mathrm{~mL}^{-1}\right)^{-1}\right)$ geradas na fase exponencial da cinética enzimática, realizada sob mesmas condições. A equação é resultado da regressão linear que permite a conversão de sacarose à inulina 


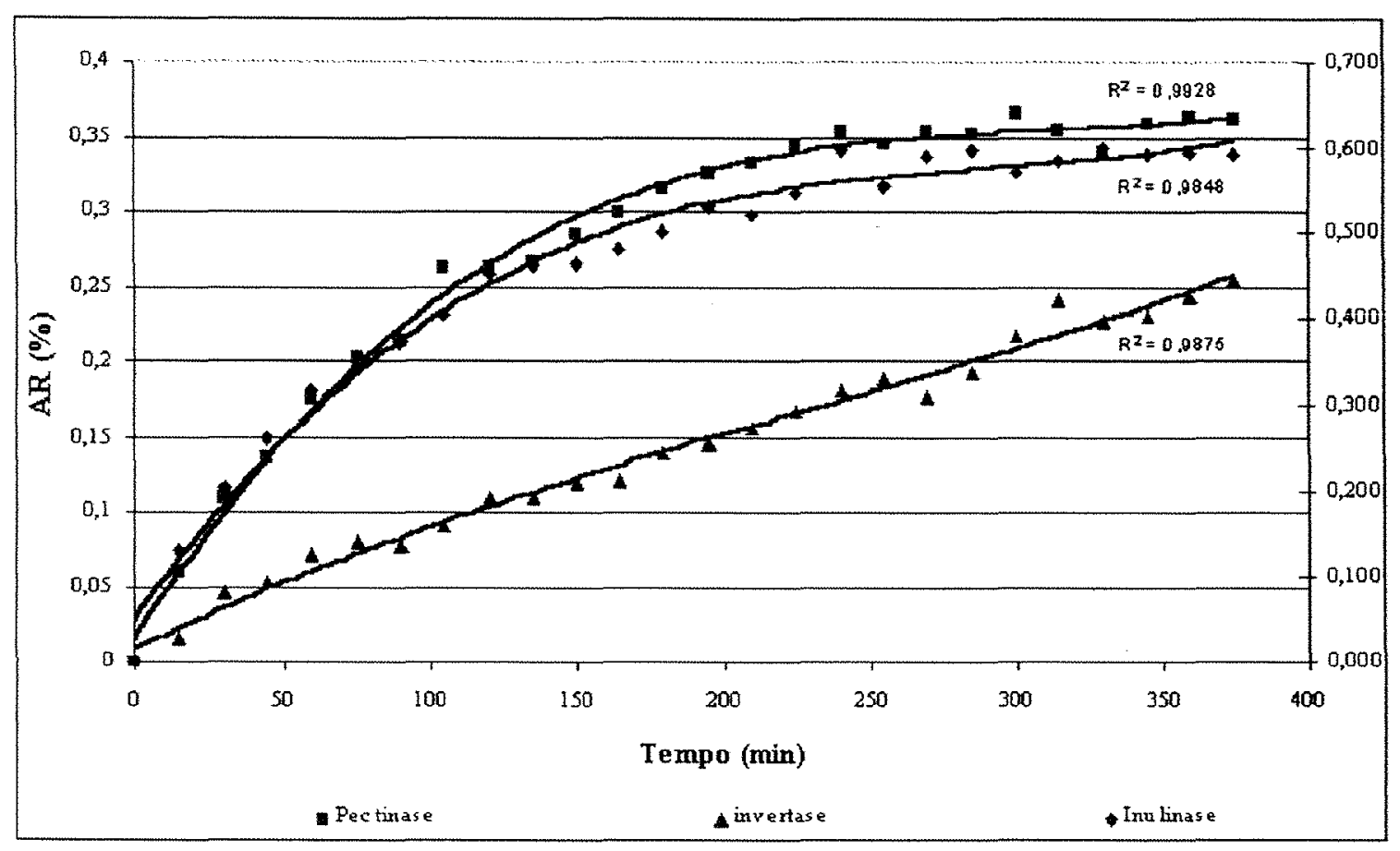

Figura 23 - Formação de açúcares redutores (média de três ensaios) por $\mathrm{mL}$ de sobrenadante contendo proteína no decorrer do tempo. A curva representada pelos losangos representa a formação de açucares redutores formados à partir da inulina (eixo secundário); a curva representada por triângulos representa a formação de açucares redutores formados à partir da sacarose (eixo primário) e a curva representada por quadrados representa a formação de açucares redutores formados à partir da pectina (eixo primário)

Os ensaios realizados para a determinação de $\mathrm{Km}$ apresentaram para inulina valores de $\mathrm{Km}=5,633$ e Vmáx $=0,8138$ por Michaelis-Menten, já pelo método de Lineweaver-Burk Km $=3,51$ e Vmax $=0,5973$ (Figura 24). Para o substrato sacarose os valores obtidos foram $\mathrm{Km}=5,307$ e Vmax $=5,308$, por Michaelis-Menten e de $\mathrm{Km}=$ 6,02 e Vmáx $=5,859$, por Lineweaver-Burk (Figura 25). 

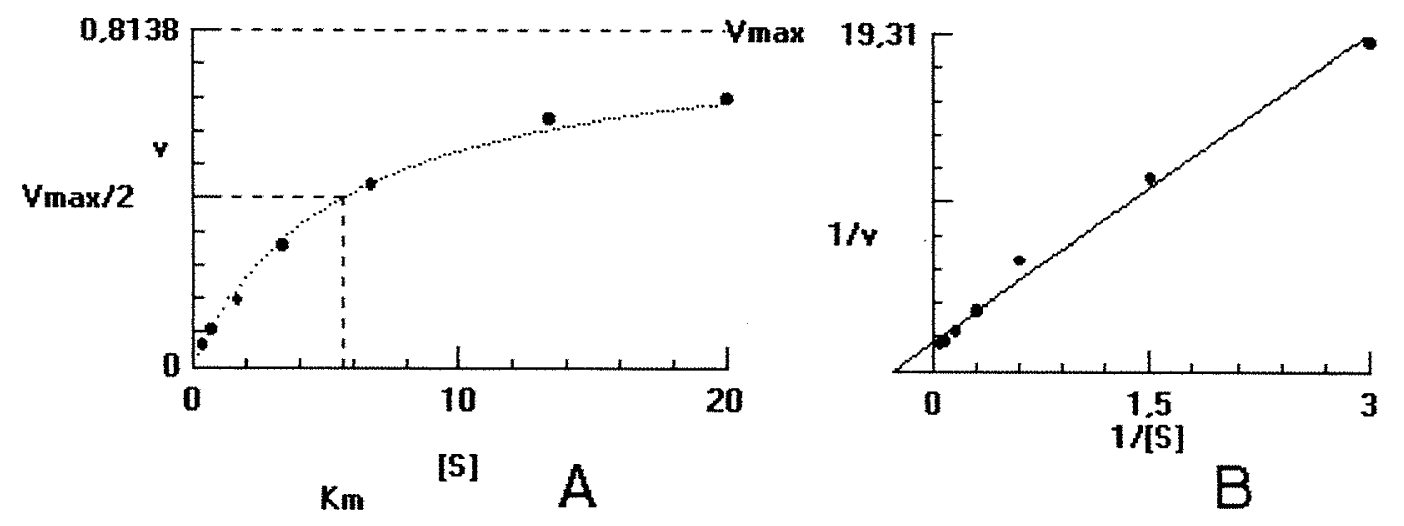

Figura 24 - Representações gráficas do cálculo de Km e Vmáx para o substrato inulina gerado pelo programa "Hyperbolic Regression" à partir dos valores obtidos experimentalmente. $\mathrm{O}$ gráfico $\mathrm{A}$ elaborado pelo método de MichaelisMenten e o B por Lineweaver-Burk
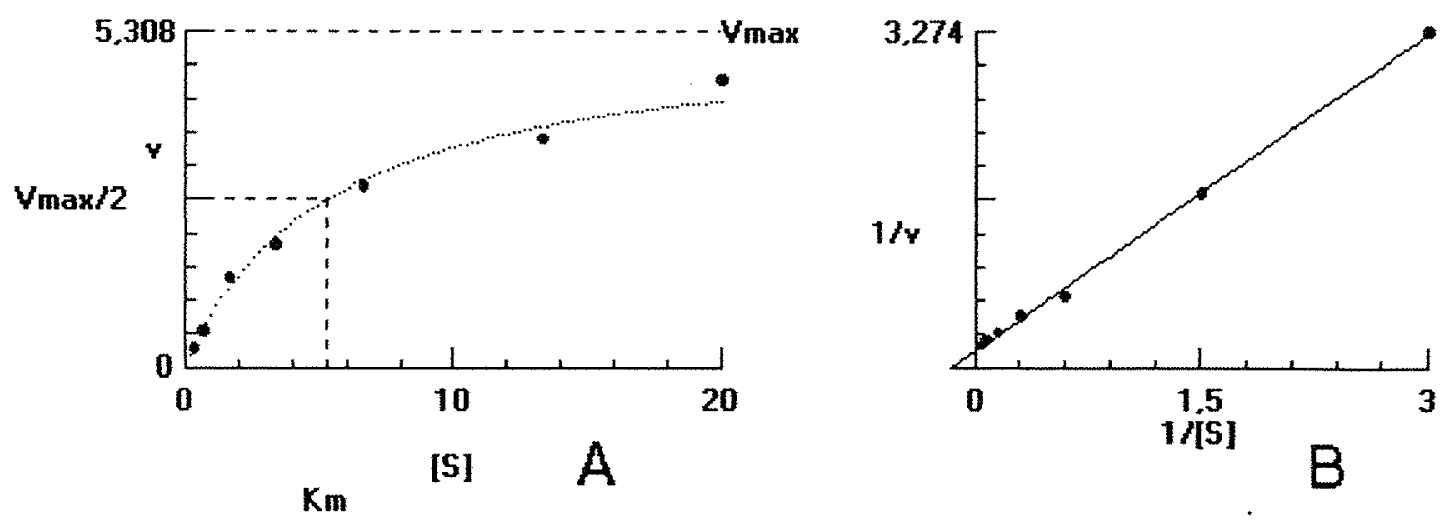

Figura 25 - Representações gráficas do cálculo de Km e Vmáx para o substrato sacarose gerado pelo programa "Hyperbolic Regression" à partir dos valores obtidos experimentalmente. O gráfico A elaborado pelo método de MichaelisMenten e o B por Lineweaver-Burk

Os ensaios realizados com pectina para a determinação de Km não possibilitaram a realização do cálculo de $\mathrm{Km}$ ou Vmáx, já que a sua grande afinidade pela enzima em 
questão não permitiu sua saturação. Os ensaios realizados com baixas concentrações da enzima geraram valores abaixo da sensibilidade do método de detecção de açucares redutores. $\mathrm{O}$ aumento da concentração do substrato impossibilita uma análise adequada já que a sua viscosidade impossibilita qualquer tentativa de medição de volume.

\subsection{Atividades de invertase e inulinase no sistema descontínuo.}

Este experimento comparou a produção de açúcares redutores nas matrizes: quitina, alginato, nylon $6^{\circledR}$, Poliestireno expandido (isopor) e o copolímero alginato-gelquitosana em sistema descontínuo, ou batelada, que consiste em um sistema fechado, sem a entrada ou saída de quaisquer um de seus componentes, resultando no acúmulo de produtos e consumo de substrato. Foram realizados ensaios com a atividade de invertase (Tabela 2) e de inulinase (Tabela 3). Também foi medida a porcentagem de atividade da enzima imobilizada em relação ao padrão que é a enzima livre no sobrenadante de Kluyveromyces marxianus MMIII-41 (Tabelas 2 e 3). Os dados gerados neste sistema demonstraram que a diferença entre as atividades de invertase nas matrizes, copolímero alginato-gel-quitosana, quitina, nylon $6^{\circledR}$, alginato, e poliestireno (Tabela 2) não é tão evidente, salvo para o isopor ou poliestireno expandido.

Tabela 2. Açúcares redutores formados à partir da sacarose nas diferentes matrizes imobilizadas em sistema batelada. A atividade relativa é a porcentagem de atividade encontrada em relação à atividade do sobrenadante original no mesmo tempo

\begin{tabular}{ccc}
\hline Amostra & $\begin{array}{c}\text { AR } \\
(\%)\end{array}$ & $\begin{array}{c}\text { Atividade relativa } \\
(\%)\end{array}$ \\
\hline Quitina & 1,29 & 18,33 \\
Alginato & 1,26 & 17,92 \\
Nylon 6 & 0,88 & 12,50 \\
Poliestireno expandido & 0,35 & 5,00 \\
Copolimero Alginato/Gel-quitosana & 1,24 & 17,50 \\
\hline
\end{tabular}


Nos ensaios realizados em sistema descontínuo, com inulina como substrato, encontrouse uma correlação muito interessante entre a quantidade de proteína imobilizada devido ao tipo de imobilização, e a atividade enzimática, pois as duas matrizes que apresentaram imobilização por aprisionamento foram as matrizes com melhor imobilização. Já as matrizes nas quais a imobilização se daria por ligações covalentes, não só apresentaram uma menor imobilização como também uma menor atividade, sendo a quitina a melhor nesta categoria em relação à atividade (Tabela 3 e Figura 26). É certo que a imobilização em quitina apresenta atividade especifica mais alta do que em alginato-gel-quitosana, porém sua saturação pela enzima é menor e por isso, há uma menor eficiência no reator.

Tabela 3. Imobilização nas diferentes matrizes no sistema descontínuo com inulina como substrato. Comparação de atividade e proteínas imobilizadas

\begin{tabular}{lccccc}
\hline \multicolumn{1}{c}{ Matriz } & \multicolumn{4}{c}{ Análise de proteína } & Atividade \\
& $\begin{array}{c}\text { Sobrenadante } \\
\text { Original } \\
(\mathrm{mg})\end{array}$ & $\begin{array}{c}\text { Sobrenadante } \\
\text { restante }(\mathrm{mg})\end{array}$ & $\begin{array}{c}\text { Água de } \\
\text { lavagem } \\
(\mathrm{mg})\end{array}$ & $\begin{array}{c}\text { Imobilizado } \\
(\mathrm{mg})\end{array}$ & $\begin{array}{c}\text { Enzimática } \\
\left(\mathrm{mM} \mathrm{prot.x} \mathrm{mL}^{-1}\right)\end{array}$ \\
\hline Alginato & 12121,2 & 3441,56 & 378,79 & 8300,87 & 3350,691 \\
Alginato-gel- & 12121,2 & 1082,25 & 2759,74 & 8279,22 & 11987,386 \\
quitosana & 12121,2 & 10216,45 & 140,69 & 1764,07 & 4448,331 \\
Quitina & 12121,2 & 9112,55 & 292,21 & 2716,45 & 3264,035 \\
Isopor & 12121,2 & 8787,88 & 930,74 & 2402,60 & 1415,378 \\
Isopor colapsado & 12121,2 & 8376,62 & 140,69 & 3603,90 & 1762,001 \\
Nylon 6 & & & & & \\
\hline
\end{tabular}




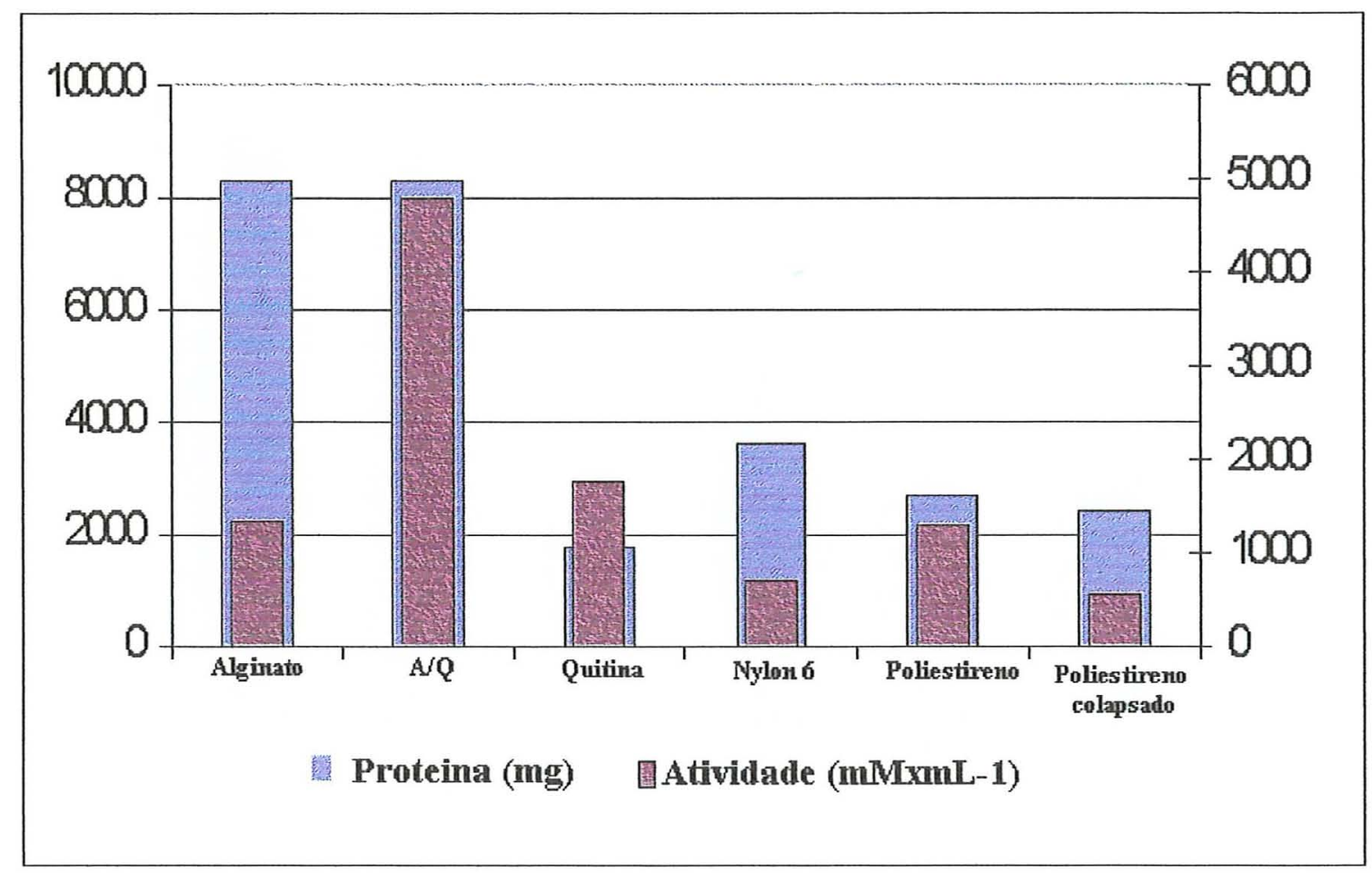

Figura 26 - Imobilização da enzima inulinase nas diferentes matrizes no sistema descontínuo. As barras de coloração vinho representam a atividade da enzima $\left(\mathrm{mMxmL}^{-1}\right)$ e as barras azuis a proteína imobilizada $(\mathrm{mg})$ medida pela diferença entre o montante total de proteína inicial no sobrenadante subtraindo-se a proteína do restante e a proteína desprendida na água de lavagem

O copolímero alginato-gel-quitosana apresentou melhor atividade que o alginato devido a sua estrutura mais "frouxa", perceptível pela dureza das esferas formadas em comparação às esferas formadas pelo alginato, o que confere à matriz uma maior permeabilidade ao substrato. Wiseman (1985), já recomendava esse tipo de situação para um bom processo de imobilização.

\subsection{Atividade de enzimas imobilizadas no sistema contínuo}

Os experimentos realizados em sistema contínuo geraram resultados que confirmam a preferência ao copolímero alginato-gel-quitosana, pois as demais matrizes 
apresentaram problemas operacionais que inviabilizaram a sua utilização, resultando na indicação desta como a melhor matriz a ser utilizada (Tabela 4).

A Tabela 4 resume os resultados obtidos com ensaios de imobilização nas mesmas matrizes no sistema contínuo (exceção para o isopor colapsado), utilizando-se três tipos de imobilizações frente ao substrato sacarose a $10 \%$. Na coluna denominada, "ocorrências em sistema contínuo", observamos os problemas enfrentados quando o ensaio é submetido a esse sistema com o tempo de residência de $1 \mathrm{~mL} \times \min ^{-1}$ à temperatura de $38^{\circ} \mathrm{C}$.

Observa-se que com a utilização da quitina no sistema contínuo, a quantidade de açúcares redutores formados é baixa, o que faz com que essa matriz não seja interessante do ponto de vista industrial. Além disso, essa matriz seria inviável em um processo industrial dada a grande quantidade empregada para preencher uma coluna de hidrólise; possivel aumento do volume da quitina decorrente da absorção de água proveniente do substrato; e pela facilidade desta se compactar, impossibilitando a utilização desta matriz para processos cujo substrato tenda a se acumular causando o entupimento da coluna de reação com conseqüente aumento de pressão e bloqueio do fluxo. Isto pôde ser observado numa tentativa de se clarificar suco de caju pela hidrólise da pectina em nosso laboratório. Problemas semelhantes foram observados por Baruque Filho et al. (2001), que mostraram uma intensa queda na velocidade de reação de sua enzima e atribuíram ao desprendimento da enzima por lavagem, estresse mecânico e bloqueio do fluxo por compactação.

$\mathrm{O}$ isopor pareceu ser um suporte muito promissor devido a sua porosidade e grande quantidade de cargas livres ocasionando uma excelente capacidade de promover ligações por interações eletrostáticas. Os resultados obtidos em sistema batelada foram bons, porém ao ser submetido ao fluxo contínuo não apresentou hidrólise do substrato, pois a enzima, desprendeu-se da matriz muito rapidamente devido a pequenas alterações no $\mathrm{pH}$.

O nylon $6^{(\circledast)}$ foi talvez uma das mais citadas matrizes encontradas na literatura, mostrou grande potencial teórico devido ao tipo de ligação com proteínas, o que poderia 
resultar em uma ótima matriz para a nossa enzima. Testamos dois protocolos citados na literatura conforme descrito no item, "materiais e métodos" mas a atividade foi nula no sistema contínuo. Ainda não conseguimos determinar o que impediu a ligação da enzima à matriz. A perda de atividade enzimática no nylon $6^{\circledast}$ deve ser investigada com mais cuidado pois, este tipo de ligação é muito estável e deveria resultar teoricamente em uma ótima matriz.

O alginato tem demonstrado ótimos resultados como matriz, porém ao ser submetido ao fluxo contínuo, se desfaz após algumas horas em contato com o substrato (quando submetido à hidrólise em extrato de Helianthus tuberosus) pela quelação do cálcio que estrutura o gel.

Pensando no problema de desintegração do gel formado pelo alginato, foi testada a possibilidade de se estabilizar o mesmo com quitosana. O protocolo seguido apresentou também outra vantagem. A imobilização se daria por ligações covalentes entre o polissacarídeo quitosana e a proteína através do glutaraldeído, e não pelo simples aprisionamento da enzima no alginato. Sabe-se que o desejável para a imobilização de enzimas é que esta seja realizada por ligações covalentes, já que esse tipo de ligação é mais estável resultando em uma estrutura mais duradoura. A ligação ao copolímero alginato gel-quitosana gerou excelentes valores e parece que se otimizou a atividade enzimática, dada a alta atividade, mesmo com a imobilização de apenas $4 \%$ frente à atividade do sobrenadante de Kluyveromyces marxianus MMII-41 original. Este valor foi conseguido pela diferença de atividade entre o sobrenadante residual e o original, sendo que o mesmo apresentou uma atividade de aproximadamente $96 \%$ da atividade original do sobrenadante original. 
Tabela 4. Resultados obtidos na imobilização da enzima de $K$. marxianus MMIII - 41 em diferentes matrizes. A atividade relativa é a porcentagem de atividade encontrada em relação à atividade do extrato original

\begin{tabular}{cccc}
\hline Matriz & $\begin{array}{c}\text { Mecanismo de } \\
\text { Imobilização }\end{array}$ & $\begin{array}{c}\text { Atividade relativa } \\
\text { Descontínuo 30 }\end{array}$ & $\begin{array}{c}\text { Atividade relativa } \\
\text { Contínuo após } 1 \mathrm{~h} \\
(\%)\end{array}$ \\
\hline $\begin{array}{c}\text { Quitina } \\
\text { Alginato }\end{array}$ & $\begin{array}{c}\text { Ligações covalentes } \\
\text { Aprisionamento }\end{array}$ & 20,86 & 14,86 \\
$\begin{array}{c}\text { Poliestireno } \\
\text { expandido }\end{array}$ & Interações eletrostáticas & 6,88 & 0,00 \\
$\begin{array}{c}\text { Nylon 6 } \\
\text { Copolímero }\end{array}$ & Ligações covalentes & 19,70 & 0,00 \\
Alginato-gel- & Ligações covalentes & 26,52 & 0,00 \\
quitosana & & & 64,19 \\
\hline
\end{tabular}

\subsection{Experimentos com o copolímero alginato-gel-quitosana}

$\mathrm{Na}$ realização do ensaio de atividade enzimática no sistema descontínuo com copolímero alginato-gel-quitosana foram gerados os dados mostrados na Figura 27. Nota-se claramente o declínio da atividade enzimática de um ensaio para o outro demonstrando que mesmo congelada em freezer comum, a enzima perde a sua atividade. De fato, ao observarmos isso, realizamos um experimento que confirmou a perda de atividade (Figura 28). Neste experimento foi estimado que o tempo de meia vida da enzima à temperatura de $0^{\circ} \mathrm{C}$ foi de aproximadamente 15 dias, o que vai de encontro ao trabalho de Pessoa Jr. \& Vitolo, (1999), que discute a queda da atividade enzimática em temperaturas de congelamento. Esses resultados levaram à necessidade de se ajustar a metodologia para os ensaios subseqüentes. Para tanto estocou-se o sobrenadante de Kluyveromyces marxianus MMIII-41 com a enzima concentrada, aliqüotada e congelada à temperatura de $-80^{\circ} \mathrm{C}$. Com isso, apesar da possibilidade de ocorrer esse problema no congelamento e descongelamento, a atividade se manteve quase inalterada, de forma que a temperatura de congelamento também influencia na estabilidade da enzima. 


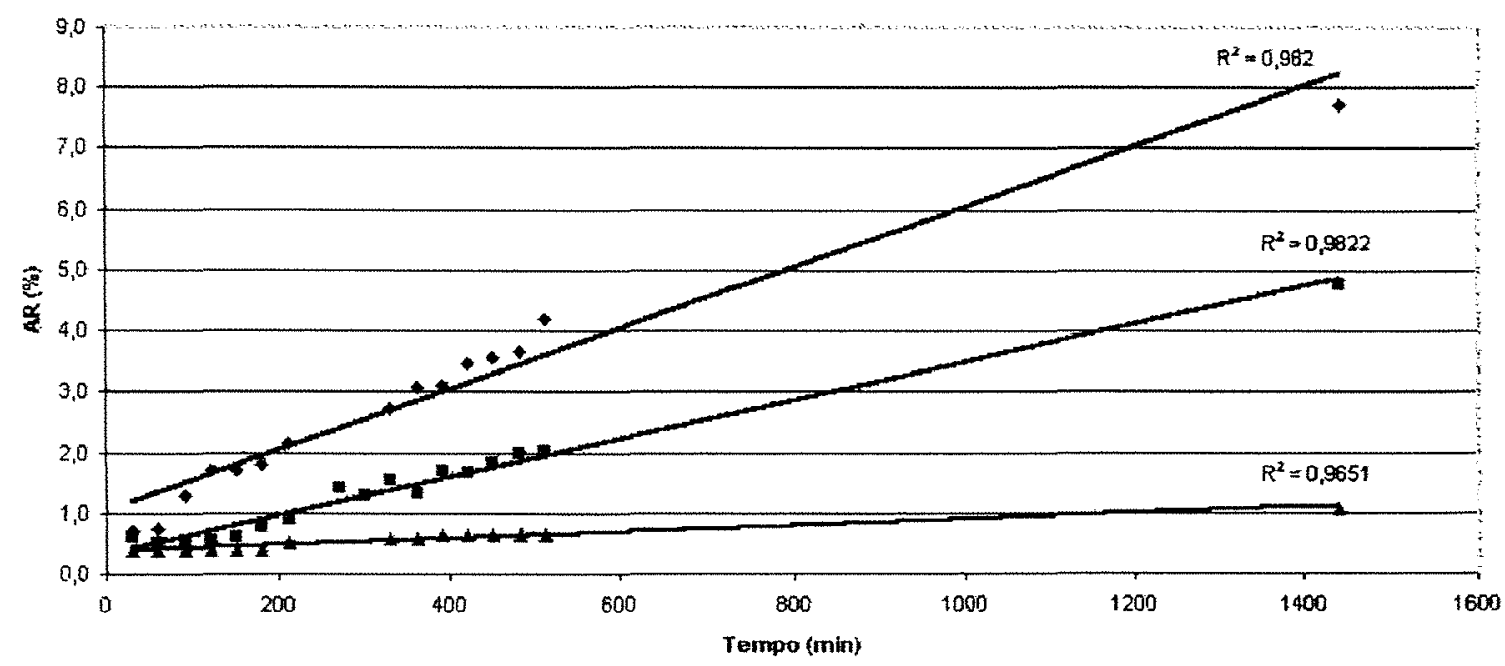

- Ensaio 1 Ensaio 2 - Ensaio $3-$ Linear (Ensaio 1) - Linear (Ensaio 2) - Linear (Eriseio 3)

Figura 27 - Comparação de três ensaios realizados em copolímero alginato-gel-quitosana no sistema descontinuo. Os ensaios foram exatamente iguais apenas com o tempo de estocagem da enzima diferente, sendo o primeiro ensaio o representado por losangos, o segundo por quadrados e o terceiro por triângulos 


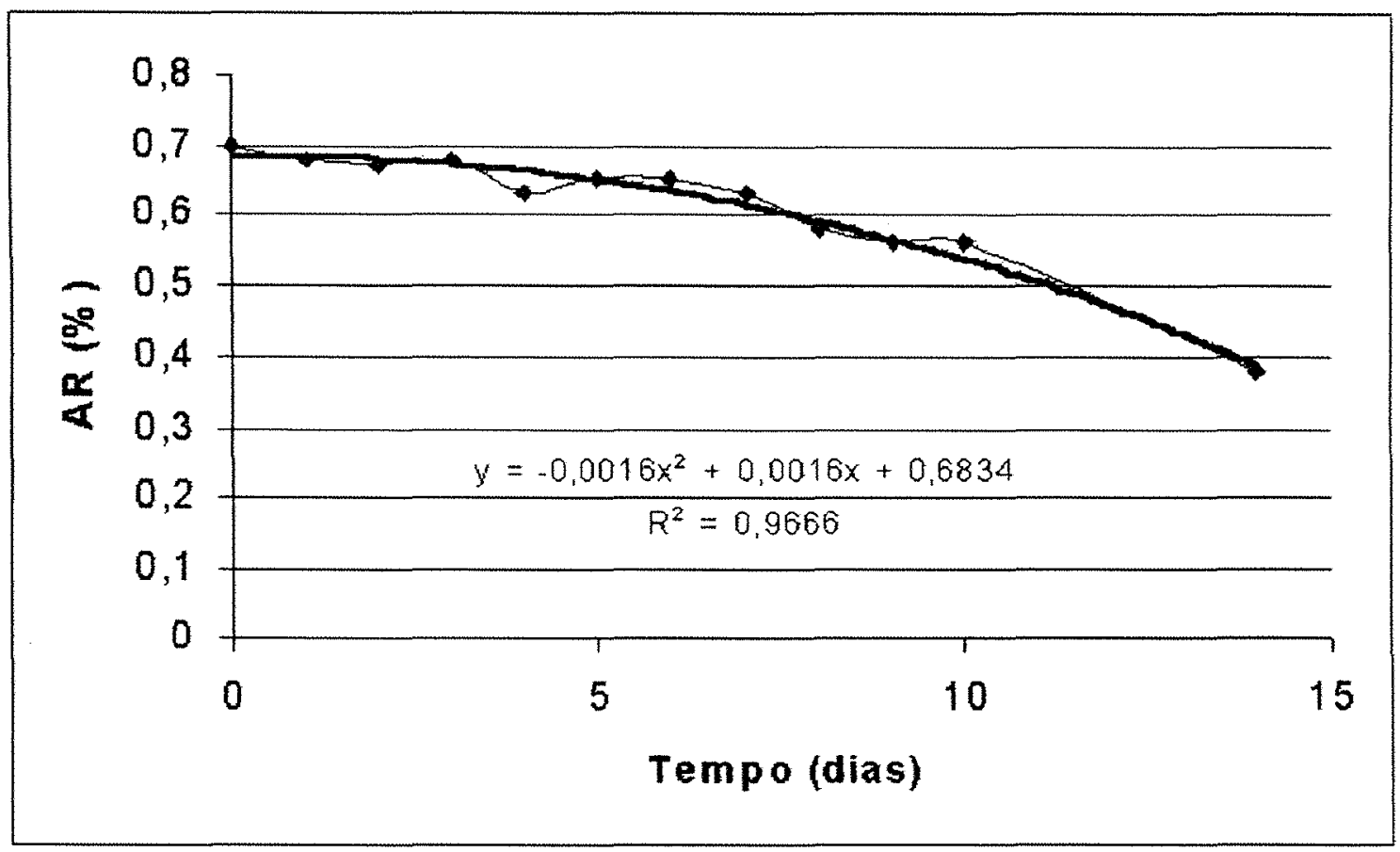

Figura 28 - Atividade enzimática no decorrer dos dias nas condições do experimento (enzima congelada em freezer comum)

Os ensaios realizados em sistema descontínuo demonstraram que apesar dos resultados positivos da precipitação com sulfato de amônio a atividade da enzima cai para $34,8 \%$ da atividade original contra os $54,2 \%$ da atividade observada com o extrato bruto imobilizado. Apesar disso parece haver um aumento dessa atividade no extrato purificado imobilizado ficando a atividade em $49,3 \%$ do valor do extrato original (Tabela 5). Mas se considerarmos que ainda assim a atividade do imobilizado proveniente do sobrenadante original é superior à observada na resultante do extrato purificado, sugerindo que não há necessidade de realização dessa etapa, já que incorre em custos adicionais a um processo. 
Tabela 5. Resultados médios dos ensaios em sistema descontínuo que determinam as porcentagens de atividade da enzima imobilizada e de proteínas totais em relação ao extrato original e extrato purificado por precipitação com sulfato de amônio

\begin{tabular}{ccccc}
\hline Amostra & $\begin{array}{c}\text { \%AR } \\
\text { média }\end{array}$ & $\begin{array}{c}\text { Prot. } \\
\text { média }\end{array}$ & $\begin{array}{c}\text { \% AR em } \\
\text { rel. ao original rel. ao original }\end{array}$ & $\begin{array}{c}\text { Prot.\% em } \\
\text { Extrato Original }\end{array}$ \\
Imobilizado AVQ & 1,78 & 235,54 & 100 & 100 \\
Extrato restante & 0,97 & 108,39 & 54,2 & 46,02 \\
Extrato Purificado & 0,65 & 61,84 & 36,5 & 26,26 \\
\hline Purif. Imobilizado AV & 0,62 & 170,62 & 34,8 & 72,4 \\
Purificado restante & 0,88 & 48,00 & 49,3 & 20,4 \\
\hline
\end{tabular}

Os ensaios realizados em sistema contínuo demonstraram a capacidade de retenção da enzima no copolímero alginado-gel-quitosana e sua viabilidade durante o período de 21 h (Figura 29). Observa-se uma perda inicial de proteínas atribuída às proteínas que não se fixaram no copolímero. A partir da terceira ou quarta hora os valores de proteína nas amostras é constante, o que pode ser atribuído à perda natural de proteína deste copolímero no decorrer do tempo. A atividade se mantém praticamente inalterada a partir da quinta ou sexta hora, sendo que as oscilações podem ser atribuídas ao erro experimental. 


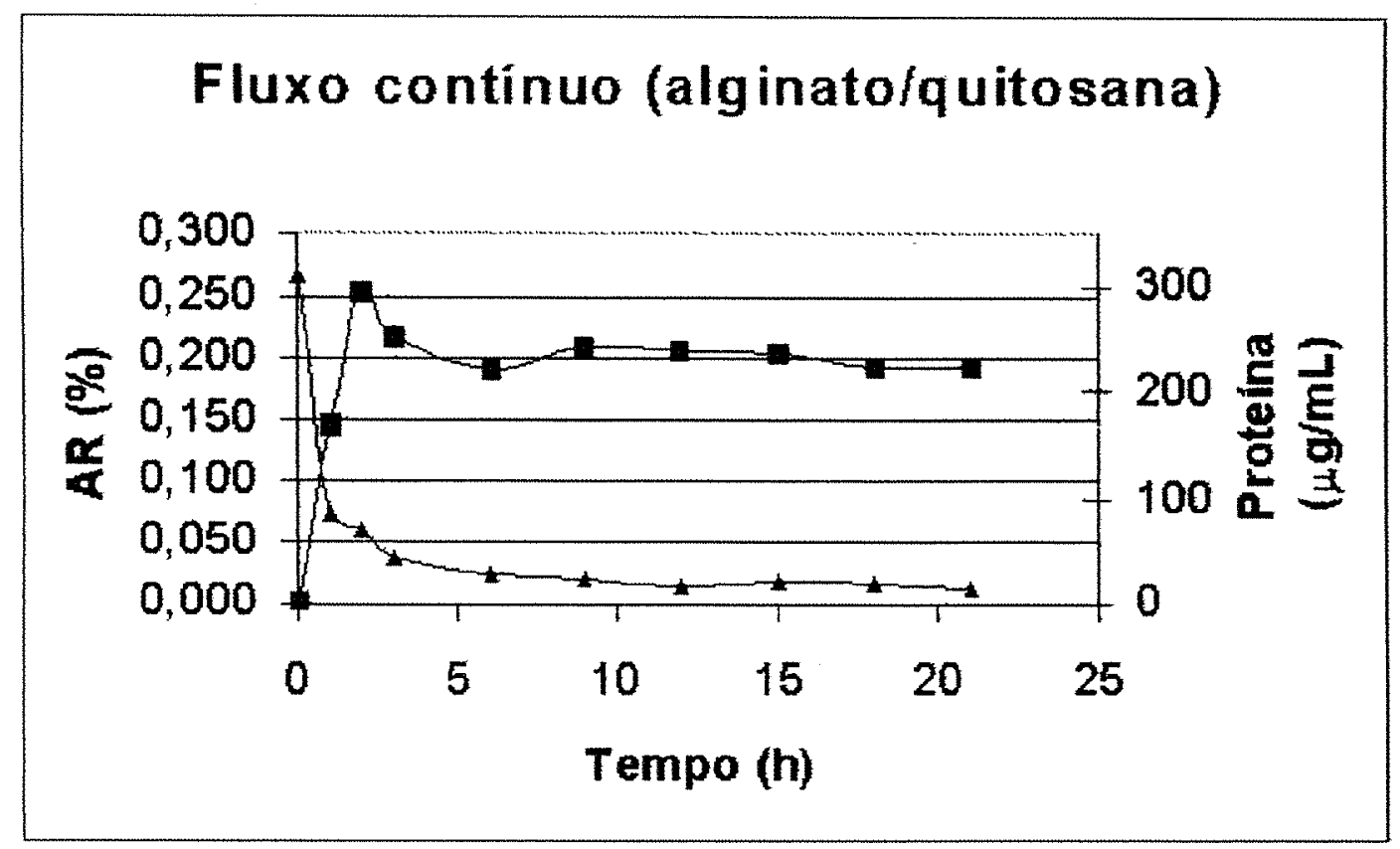

Figura 29 - Atividade enzimática no copolímero alginato-gel-quitosana em ensaios de fluxo contínuo. A os triângulos representam a concentração de proteínas totais detectada no produto. O valor representado no tempo zero é a quantidade de proteina do sobrenadante original. Os quadrados representam a atividade enzimática (açúcares redutores $\% \times \min ^{-1} \times 10^{-3}$ ) no decorrer do tempo

Em um ensaio mais longo observamos que não há queda considerável na atividade da enzima (Figura 29), quer seja a imobilizada quer seja a enzima livre do controle por todo o período de duração do experimento que foi de 17 dias. Observa-se um ligeiro aumento na atividade enzimática do material imobilizado, provavelmente devido às mudanças na estrutura da matriz durante o experimento aumentando a exposição da enzima ao substrato até a total dissolução da matriz que aconteceu repentinamente no décimo sétimo dia de experimento, o que determina o período máximo de aproveitamento da enzima nesta matriz. Pode-se considerar frente a estes resultados que o fator determinante para a vida útil de um processo utilizando-se essa matriz é única e exclusivamente a estabilidade da matriz e não a enzima em si. 


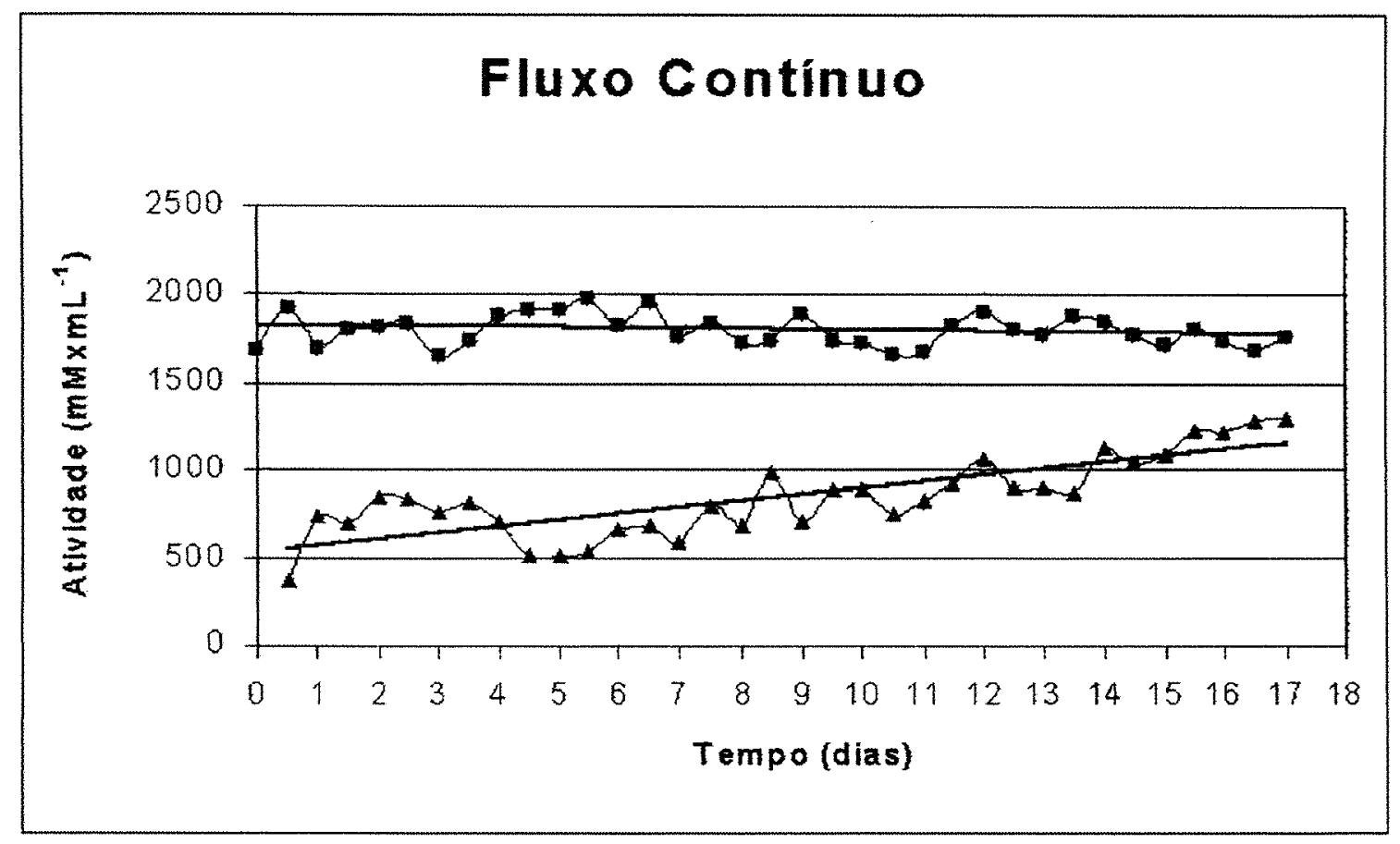

Figura 30 - Atividade enzimática em função do tempo no ensaio de fluxo contínuo do sobrenadante imobilizado no copolímero alginato-gel-quitosana frente à sacarose. Os triângulos mostram a atividade do sobrenadante imobilizado enquanto que os quadrados mostram a atividade da enzima livre (controle) até a dissolução da matriz

Foi realizado um ensaio de atividade de inulinase no sistema descontínuo utilizando-se o copolímero alginato-gel-quitosana imobilizado por aprisionamento e por ligações covalentes seguindo-se os protocolos descritos anteriormente.

Os resultados da Tabela 6 e Figura 31 demonstraram uma atividade de inulinase superior na matriz imobilizada por ligações covalentes em relação à matriz imobilizada por aprisionamento e inclusive em relação ao extrato original. Isso é possível se a imobilização por ligações covalentes altera a conformação da enzima (Wiseman, 1985). No caso das atividades de invertase e pectinase (Figuras 32 e 33 e Tabelas 7 e 8) o comportamento foi inverso, ou seja, a imobilização por ligações covalentes apresentou uma menor eficiência, em torno da metade da atividade observada por aprisionamento, o que pode ser explicado por uma alteração na conformação da proteína que, neste caso, 
poderia prejudicar os sítios ativos para essas duas atividades (Wiseman, 1985). A Figura 34 mostra a diferença de aspecto do mesmo copolímero alginato-gel-quitosana quando submetido aos diferentes tipos de imobilização aprisionamento e ligações covalentes. Observa-se que as esferas quando submetidas à presença do glutaraldeído se tornam mais compactas sendo reduzidas ao diâmetro de $1 \mathrm{~mm}$, aproximadamente um terço do seu tamanho quando na ausência do mesmo.

Tabela 6. Resultados médios dos ensaios em sistema descontínuo na comparação da atividade de inulinase entre as imobilizações por ligações covalentes e por aprisionamento no copolímero alginato-gel-quitosana

\begin{tabular}{cccc}
\hline Amostra & AR \% & $\begin{array}{c}\text { Atividade } \\
\left(\mathrm{mMxmL}^{-1}\right)\end{array}$ & $\begin{array}{c}\text { Proteína } \\
\left(\mathrm{mgxmL}^{-1}\right)\end{array}$ \\
\hline Sobrenadante original & 21,899 & 7299,78 & 57,605 \\
AVQ ligação covalente & 28,184 & 9394,75 & 38,641 \\
AVQ aprisionamento & 16,508 & 5502,77 & 33,883 \\
\hline
\end{tabular}




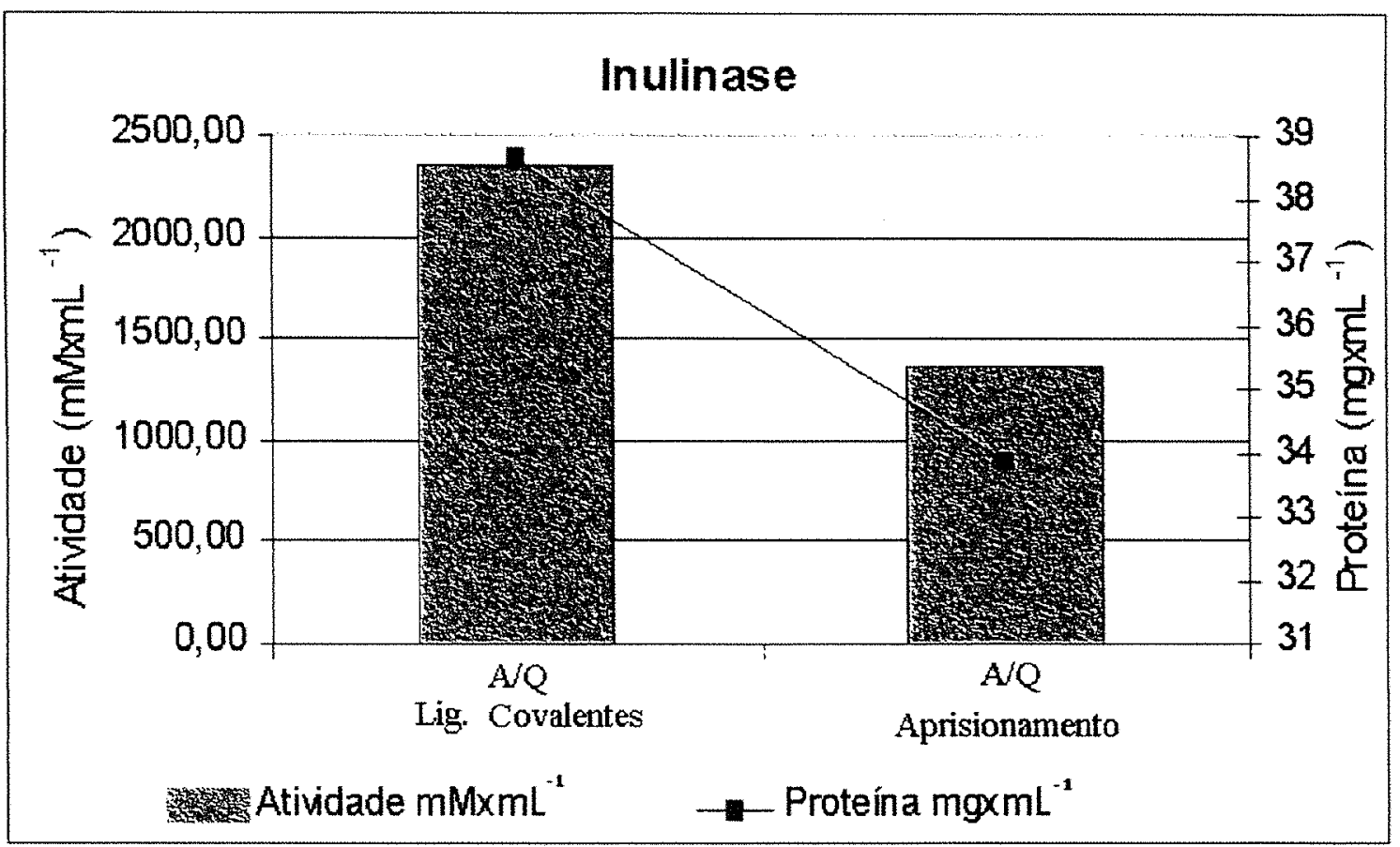

Figura 31 - Comparação atividade de inulinase e proteina imobilizada entre as diferentes formas de imobilização no copolímero alginato-gel-quitosana, ligações covalentes e por aprisionamento

Tabela 7. Resultados médios dos ensaios em sistema descontínuo na comparação da atividade de invertase entre as imobilizações por ligações covalentes e por aprisionamento no copolímero alginato-gel-quitosana

\begin{tabular}{cccc}
\hline Amostra & AR \% & $\begin{array}{c}\text { Atividade } \\
\left(\mathrm{mMxmL}^{-1}\right)\end{array}$ & $\begin{array}{c}\text { Proteina } \\
\left(\mathrm{mgxmL}^{-1}\right)\end{array}$ \\
\hline extrato & 57,699 & 76932,02 & 57,605 \\
A/Q ligação covalente & 14,391 & 19187,89 & 38,641 \\
A/Q aprisionamento & 15,744 & 20992,40 & 33,883 \\
\hline
\end{tabular}




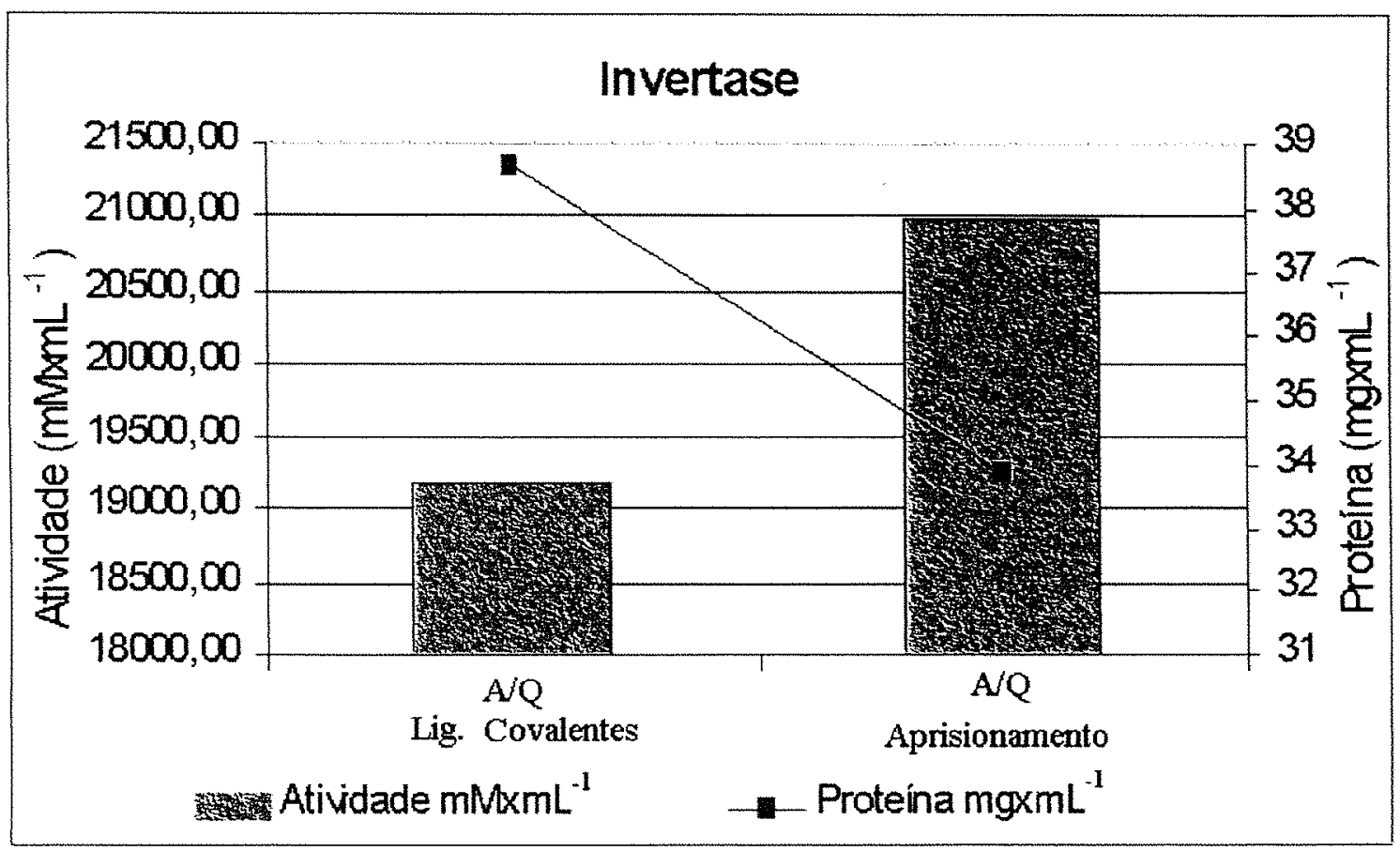

Figura 32 - Comparação atividade de invertase e proteína imobilizada entre as diferentes formas de imobilização no copolímero alginato-gel-quitosana, ligações covalentes e por aprisionamento

Tabela 8. Resultados médios dos ensaios em sistema descontínuo na comparação da atividade de pectinase entre as imobilizações por ligações covalentes e por aprisionamento no copolimero alginato-gel-quitosana

\begin{tabular}{cccc}
\hline Amostra & AR \% & $\begin{array}{c}\text { Atividade } \\
\left(\mathrm{mMxmL}^{-1}\right)\end{array}$ & $\begin{array}{c}\text { Proteína } \\
\left(\mathrm{mgxmL}^{-1}\right)\end{array}$ \\
\hline extrato & 30,586 & 40701,79 & 57,605 \\
A/Q ligação covalente & 6,414 & 8551,34 & 38,641 \\
A/Q aprisionamento & 7,414 & 9884,67 & 33,883 \\
\hline
\end{tabular}




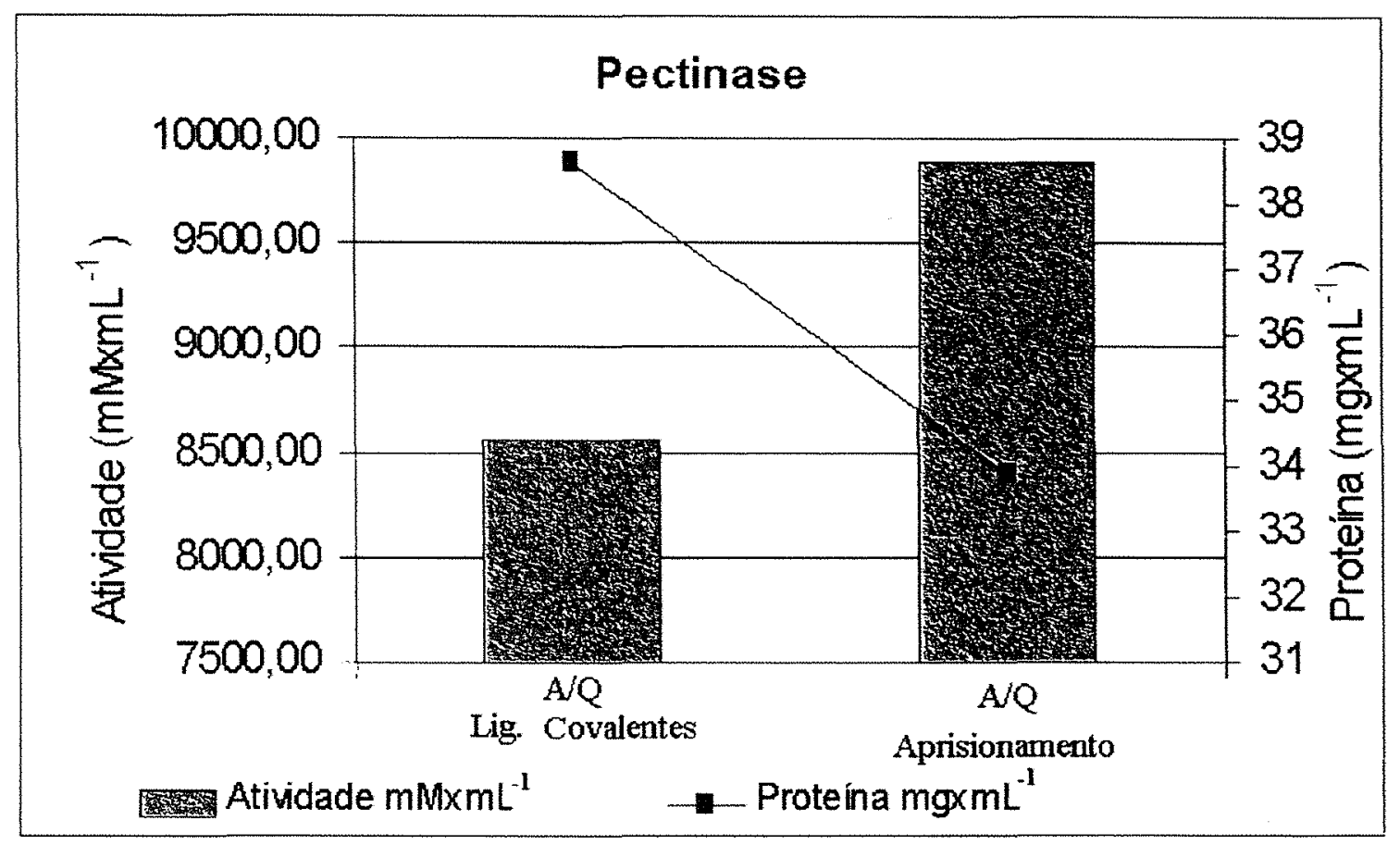

Figura 33 - Comparação atividade de pectinase e proteína imobilizada entre as diferentes formas de imobilização no copolímero alginato-gel-quitosana, ligações covalentes e por aprisionamento 


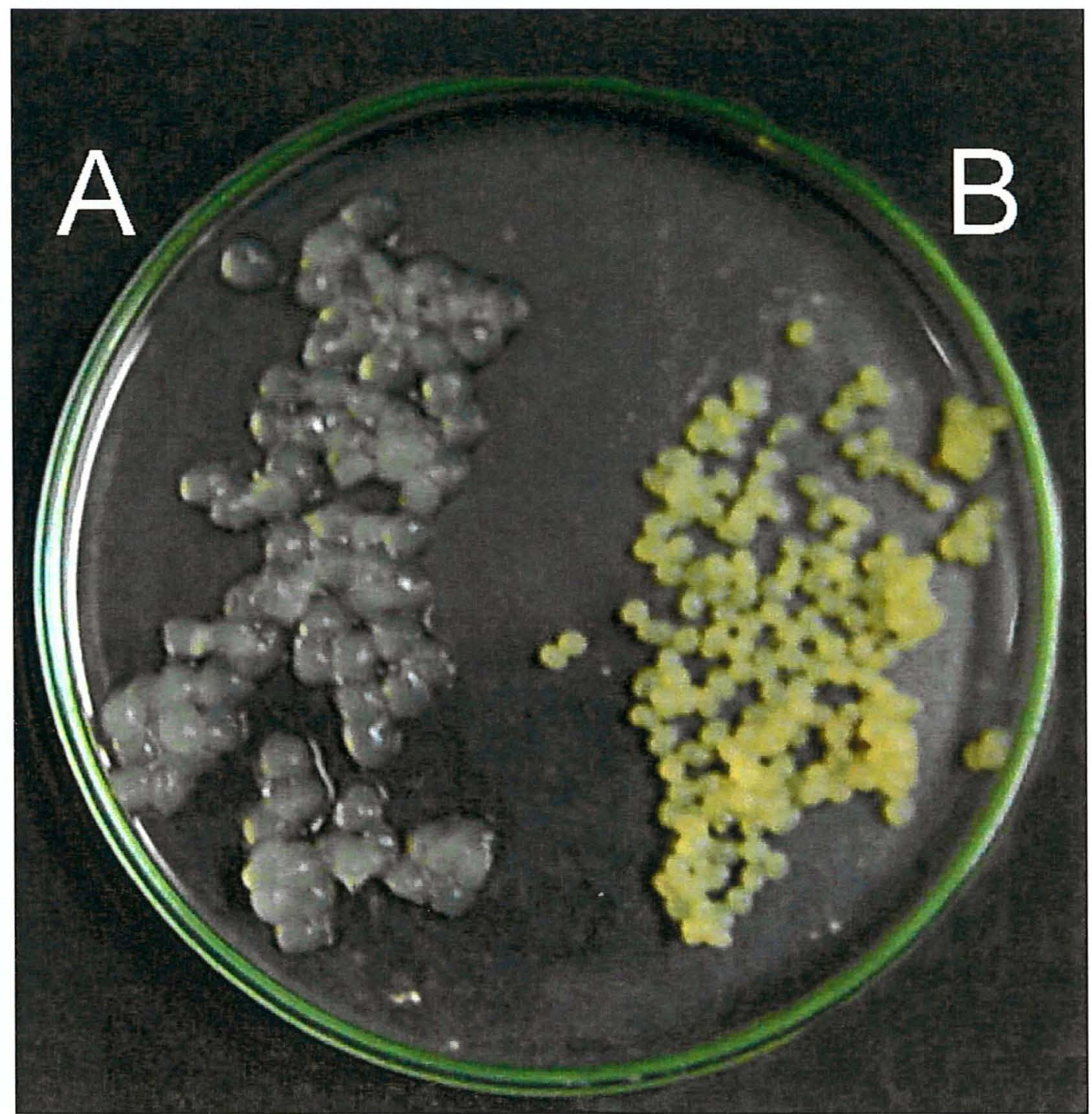

Figura 34 - Foto demonstrando a diferença de aspecto e diâmetro das esferas do copolímero alginato-gel-quitosana imobilizado por aprisionamento (A) e por ligações covalentes (B) 


\section{CONCLUSÕES}

- A melhor matriz para a imobilização desse sobrenadante é o alginato-gel-quitosana devido aos problemas operacionais.

- Para um processo industrial não é viável a limpeza (pré-purificação) do sobrenadante de Kluyveromyces marxianus MMIII-41, devido aos custos e problemas operacionais.

- As condições de pH e temperatura são diferentes para cada atividade (ou enzima), mas não podemos ainda afirmar se tratam-se de diferentes enzimas ou de uma polivalente.

- Para pectinase e invertase, a melhor forma de imobilização é por aprisionamento enquanto que, para inulinase, a melhor forma foi por ligações covalentes.

- Os ensaios de eletroforese não trouxeram resultados conclusivos em relação ao número de enzimas presentes no sobrenadante de Kluyveromyces marxianus MMIII-41, portanto futuramente isso deve ser melhor investigado. 


\section{REFERÊNCIAS BIBLIOGRÁFICAS}

ALBARGHOUTHI, M.; FARA, D. A.; SALEEM, M.; et al. Immobilization of antibodies on alginate-chitosan beads. International Journal of Pharmaceutics, v. 206, p. 23$34,2000$.

ALKORTA, I.; GARBISU, C.; LLAMA, MJ.; et al. Immobilization of pectin lyase from Penicillium italicum by covalent binding to nylon. Enzyme and Microbial Technology, v. 18, p. 141-146, 1996.

ALTIERI, M. Os mitos da biotecnologia agrícola: algumas considerações éticas. http://orbita.starmedia.com/ m.p.3/mitos_agr\%C3\%ADco.htm (17 out. 2002).

BARNETT, J.A.; PAYNE, R.W.; YARROW, D. Yeasts: Characteristics and identification. Cambridge University Press, Cambridge - UK; 2 ed. 1990. 1002p.

BARRANCO-FLORIDO, E; GARCÍA-GARIBAY, M; GÓMEZ-RUIZZ R. E AZAOLA, A. Immobilization system of Kluyveromyces marxianus cells in barium alginate for inulin hydrolysis. Process Biochemistry, v. 37, p. 513-519, 2001.

BARUQUE FILHO, E.A; BARUQUE, M.G.A; SANT'ANNA JUNIOR., G.L. Determination of the enzyme reaction rate in a differential fixed-bed reactor: a case study. Brazilian Journal of Chemical Engineering, v. 18, n. 1, p. 1-11, 2001.

BERGAMASCO, R.; BASSETTI, F.J.; MORAES, F.F. de; et al. Characterization of free and immobilized invertase regarding activity and energy of activation. Brazilian Journal of Chemical Engineering v.17, n. 4/7, p.873-880, 2000.

BLANCO, P.; SIEIRO, C.; VILLA, T.G. Production of pectic enzymes in yeasts. FEMS Microbiology Letters, v. 175, p. 1-9, 1999.

BILlMEYER JUNIOR, F. W. Textbook of Polymer Chemistry. New York: Ed. Interscience Publishers, 1957. 518p. 
BRADFORD, M.M. A rapid and sensitive method for the quantitation of microgram quantities of protein utilizing the principle of protein-dye binding. Analytical Biochemistry, v. 72, p. $248-254,1976$.

BYUN, S.M.; NAHM, B.H. Production of fructose from jerusalem artichoke by enzymatic hydrolysis. Journal of Food Science, v. 43, n. 6, p. 1871-1873, 1978.

CAMPERI, S.A.; HOURS, R.A.; AUDAY, R.M; et al. Jugos de Fruta sin Metanol. www.cienciahoy.org/hoy33/index.htm (18 out. 2002).

CAPITO, S.M.P. Raiz tuberosa de Yacón (Polymnia sonchifolia): Caracterização química e métodos de determinação de frutanos (CG e CLAE-DPA). São Paulo, 2001. 101 p. Dissertação (Mestrado). Faculdade de Ciências Farmacêuticas, Universidade de São Paulo.

CASTILHO, L.; MEDRONHO, R.A.; ALVES, T.L.M. Production and extraction of pectinases obtained by solid state fermentation of agroindustrial residues with Aspergillus niger. Bioresource Technology, v. 71, p. 45-50, 2000.

CEAGESP - CENTRO DE QUALIDADE EM HORTICULTURA. Procura-se: Jerusalém artichoke, www.ceagesp.com.br/NOV091001.HTM\#novid8, (21 dez. 2001).

ÇETINUS, S.A.; ÖZTOP, H.N. Immobilization of catalase on chitosan film. Enzyme and Microbial Technology, v. 26, p. 497-501, 2000.

CRUZ, V.D.; BELOTE, J.G.; BELLINE, M.Z.; et al. Production and action pattern of inulinase from Aspergillus niger-245: Hydrolysis of inulin from several sources. Revista de Microbiologia, v. 29, n. 4, p. 301-306, 1998.

CRUZ-GUERRERO, A.; GARCIA-PEÑA, I.; BARZANA, E; et al. Kluyveromyces marxianus CDBB-L-278: A wild inulinase hyperproducing strain. Journal of Fermentation and Bioengineering, v. 80, n. 2, p. 159-163, 1995.

DASHEVSKY, A. Protein loss by the microencapsulation of an enzyme (lactase) in alginate beads. International Journal of Pharmaceutics, v. 161, p. 1-5, 1998.

DESHAIES R.J.; KEPES, F.; BÖHNI, P.C. Genetic dissecation of the early stages of protein secretion in yeast. Trends in Genetics, v. 5, p. 87-96, 1989. 
DINNELLA, C.; LANZARINI, G.; MONTELEONE, E. Enzymatic carrot tissue maceration optimization by response surface analysis. Sciences des Aliments, v. 18, p. $497-505,1998$.

EASTERBY, J. S. Dr John S Easterby's Windows 3.x Software for Biochemistry http://www.liv.ac.uk/ jse/software.html (20 jan. 2003).

ETTALIBI, M.; BARATTI, J.C. Sucrose hydrolysis by thermostable immobilized inulinases from Aspergillus ficuum. Enzyme and Microbial Technology, v. 28, n. 7/8, p. 596-601, 2001.

FEDERAÇÃO DA AGRICULTURA DO ESTADO DE SÃO PAULO. Cana-de-açúcar. Informe Departamento Econômico, n. 26, p. 3-4, 1999.

FRANK, A.; LEENHEER, L.D. Inulin. Biopoly mers, v. 6, p. 439-448, 2002.

GARCÍA-CARREÑO, F.L. Proteinase inhibitors. Trends in Food Science \& Technology, v. 7, p. 197-204, 1996.

GASPARI, J.W. Imobilização da inulinase de kluyveromyces marxianus para a hidrólise de extratos de Helianthus tuberosus L. Piracicaba, 1998. 74p. Dissertação (Mestrado) Escola Superior de Agricultura "Luiz de Queiroz" Universidade de São Paulo.

GEMEINER, P.; REXOVÁ-BENKOVÁ, L. ;SVEC, F.; et al. Natural and synthetic carriers suitable for immobilization of viable cells, active organelles, and molecules. In: VELIKY, I. A.; MCLEAN, R.J.C. Immobilized Biosystems - Theory and pratical applications. New York: Chapman \& Hall. 1994. 342p.

GUPTA A.K.; SINGH, D.P.; KAUR, N.; et al. Production, purification and immobilization of inulinase from kluyveromyces fragilis. Journal of Chemical Technology and Biotechnology, v. 59, n. 4, p. 377-385, 1994.

HENRIKSSON,G; AKIN, D.E.; SLOMCZYNSKI, D.; et al. Production of higly efficient enzymes for flax retting by Rhizomucor pusillus. Journal of Biotechnology, v. 68, p. 115-123, 1999.

HORNBY, W.E.; GOLDSTEIN, L. Immobilization of enzymes on nylon. Methods in Enzymology, v. 44, p. 118-134, 1976. 
HUANG, C.; CHEIN, S.; PAN, J.R. Optimal conditions for a modification of chitosan: A biopolymer for coagulation of colloidal particles. Water Research, v. 34, n. 3, p. $1057-1062,2000$.

ISGROVE, F.H.; WILLIAMS, R.J.H.; NIVEN, G.W.; et al. Enzyme immobilization on nylon- optimization and the steps used to prevent enzyme leakage from the support. Enzyme and Microbial Technology, v. 28, p. 225-232, 2001.

JUANG, R-S.; WU, F-C.; TSENG, R-L. Solute adsortion and enzyme immobilization in chitosan beads prepared from shrimp shell wastes. Bioresource Technology, v. 80, p. 187-193, 2001.

KIM, W.Y.; BYUN, S.M. Hydrolysis of inulin from Jerusalem artichoke by inulinase immobilized on aminoethylcellulose. Enzyme and Microbial Technology, v. 4, p. 239-244, 1982.

KOCHHAR, A.; KAUR, N.; GUPTA, A.K. Inulinase from Aspergillus versicolor: A potent enzyme for producing fructose from inulin. Journal of Scientific \& Industrial Research of India, v. 56, n.12, p. 721-726, 1997.

KOCHHAR, A.; KAUR, N.; GUPTA, A.K. Purification and immobilization of inulinase from Aspergillus candidus for producing fructose. Journal of the Science of Food and Agriculture, v. 79, n. 4, p. 549-554, 1999.

KUBOTA, N.; TATSUMOTO N.; SANO T.; et al. simple preparation of half $\mathrm{N}$-acetylated chitosan highly soluble in water and aqueous organic solvents. Carbohydrate Research, v. 324, p. 268-274, 2000.

LAGUNA, S.E. Genética de melhoramento de leveduras para a bioconversão de extratos de Helianthus tuberosus L. Piracicaba, 1986. 173p. Tese (Doutorado) Escola Superior de Agricultura "Luiz de Queiroz", Universidade de São Paulo.

LASKIN, A. I. Enzymes and Immobilized Cells in Biotechnology. Menlo Park, California: Benjamin; Cummings Publishing, 1985. 317p (Biotechnology Series).

LEONEL, M.; CEREDA, M.P. Avaliação da celulase e pectinase como enzimas complementares, no processo de hidrólise-sacarificação do farelo de mandioca para a produção de etanol. Ciência e Tecnologia de Alimentos, v. 19, n.1, p. 113-117, 1999. 
LUH, B.S.; PHAFF, H.J. Studies on polygalacturonase of certain yeasts. Archives of Biochemistry and Biophysics, v. 33, p. 213-227, 1951.

LUH, B.S.; PHAFF, H.J. Properties of yeast polygalacturonase. Archives of Biochemistry and Biophysics, v. 48, p. 23-27, 1954a.

LUH, B.S.; PHAFF, H.J. End products and mechanisms of hydrolysis of pectin and pectic acid by yeast polygalacturonase. Archives of Biochemistry and Biophysics, v. 51, p. 102-113, 1954b.

MARTINO, A.; DURANTE, M.; PIFFERI, P.G.; et al. Immobilization of $\beta$-glucosidade from a commercial preparation. Part 1. A comparative study of natural supports. Process Biochemistry, v. 31, n. 3, p. 281-285, 1996.

MARTINSEN, A.; SKJAK-BRAEK, G.; SMIDSROD, O. Alginate as immobilization material: I. Correlation between chemical and physical properties of alginate gel beads. Biotechnological and Bioengineering, v. 33, p. 79-89, 1989.

MAZUELOS, A.; PALENCIA, I.; ROMERO, R.; et al. Ferric iron production in packed bed biorreactors: Influence of $\mathrm{pH}$, temperature, particle size, bacterial support material and type of air distributor. Minerals Engineering, v. 14 n. 5, p. 507-514, 2001

MIMA, S.; MIYA, M.; IWAMOTO, R.; et al. Highly deacetylated chitosan and its properties. Journal of Applied Polymer Sciences, v. 28, p. 1909-1917, 1983.

MONTEIRO JUNIOR., O. A.C.; AIROLDI, C. Some Studies of crosslinking chitosan glutaraldehyde iteraction in a homogeneous system. International Journal of Biological Macromolecules, v. 26, p. 119-128, 1999.

NAKAMURA, T.; OGATA, Y.; SHITARA, A.; et al. Continuous production of fructose syrups from inulin by immobilized inulinase from Aspergillus-niger mutant-817. Journal of Fermentation and Bioengineering, v. 80, n. 2, p. 164-169, 1995.

OREGON STATE UNIVERSITY - Jerusalém Artichoke (Helianthus tuberosus). www.orst.edu/Dept/NWREC/artichje.html, (23 abr. 2002).

OLIVEIRA, S.C.M.; BARBOSA, J.F.; MALUF, W.R. Tupinambour (Helianthus tuberosus) - A alcachofra que adoça a sua vida., Lavras: UFLA, 1999. 1 p. (Boletim Técnico de Hortaliças, 40).

PALMER, T. Understanding Enzymes. New York: ELLIS HORWOOD, 1981. 405p. 
PARK, J.P.; BAE, J.T.; YOU, D.J.; et al. Production of inulooligosaccharides from inulin by a novel endoinulinase from Xanthomonas sp. Biotechnology Letters, v. 21, n.12, p. 1043-1046, 1999.

PAZ, M.F. Influência da composição do meio de cultura, sobre as produtividades em polissacarídeo, da Neisseria meningitidis (sorogrupo C) cultivada em processo descontínui submerso. São Paulo, 1997. 72p. Dissertação (Mestrado) - Instituto de Ciências Biomédicas, Universidade de São Paulo.

PEREIRA, G.A.G. Atividade inulinolítica extracelular em Kluyveromyces marxianus. Piracicaba, 1989. 152p. Dissertação (Mestrado) - Escola Superior de Agricultura "Luiz de Queiroz", Universidade de São Paulo.

PESSOA JUNIOR., A.; VITOLO, M. Recovery of inulinase using BDBAC reversed micelles. Process Biochemstry, v. 33, p. 291-297, 1998.

PESSOA JUNIOR., A.; VITOLO, M. Inulinase from Kluyveromyces marxianus: culture medium composition and enzyme extraction. Brazilian Journal of Chemical Engineering, v. 16, n. 3, p. 237-245, 1999.

PRABHU, G.N.; CHANDRASEKARAN, M. Impact of process parameters on 1glutaminase production by marine Vibrio costicola in solid state fermentation using polystyrene as an inert support. Process Biochemistry, v. 32, n. 4, p. 285-289, 1997.

QUEIROZ, N.; NASCIMENTO, M.G. Organo-gel de heptano: diagrama de fases e aplicações sintéticas. Química Nova, v. 22, n. 3, p. 335-338,1999.

RIKIR, R.; ROBLAIN, D.; CAMPOS, D.; THONART, PH. A multipontential hydrolytic reactor using the yeast Kluyveromyces marxianus. Applied Biochemistry and Biotechnology, v. 24, n. 25, p. 511-519, 1990.

SAKAI, T. Protopectinase from yeasts and a yeastlike fungus. Methods in Enzymology, v. 161, p. 335-354, 1988.

SANCHEZ, J.; GUIRAUD, J.P.; GALZY, P. A study of the polygalacturonase activity of several yeast strains isolated from cocoa. Applied Microbiology and Biotechnology, v. 20, p. $262-267,1984$. 
SCANAVINI, H. F.A.; MAKINO Y.; RODRIGUES M. I. Estudo da otimização da produção de inulinase a partir das linhagens de Kluyveromyces. IN: CONGRESSO INTERNO DE INICIAÇÃO CIENTÍFICA, 9., Campinas, 2001. Anais Campinas: UNICAMP, 2001. p.1.

SCHWAN, R.F.; COOPER, R.M.; WHEALS, A.E. Endopolygalacturonase secretion by Kluyveromyces marxianus and other cocoa pulp-degrating yeasts. Enzyme Microbial Technology, v. 21, p. 234-244, 1997.

SCHEJTER, A.; MARCUS, L. Isozymes of pectinesterase and polygalacturonase from Botrytis cinerea Pers. Methods in Enzymology, v. 161, p. 366-373, 1988.

SOMOGYI, M. A New Reagent for the Determination of Sugars. The Journal of Biological Chemistry, v. 160, p. 61, 1945.

SRIROTH, K; CHOLLAKUP, R.; CHOTINEERANAT, S.; et al. Processing of cassava waste for improved biomass utilization. Bioresource technology, v. 71, p. 63-69, 2000 .

THONART Ph.; ROBLAIN D.; RIKIR R. Improvement of Inulin Hydrolysis yeast cell reactor by mutants selection. Applied Biochemistry and Biotechnology, v. 17, p. $193-202,1988$.

TREVAN, M. D. Immobilized enzymes - An introduction and applications in biotechnology. New York: JOHN WILEY, 1980. 138p.

TREVISAN, H.C.; MEI, L.H.I.; ZANIN, G.M. Preparation of silica with controlled pore sizes for enzyme immobilization. Brazilian Journal of Chemical Engineering, v. 17, n. 1 , p. $71-77,2000$.

UFSC. Batata Yakon. Revista eletrônica do Departamento de Química UFSC.http://www.quimica.matrix.com.br/artigos/colaboracoes/batata_yacon.html(03 dez. 2002).

WEI, W.L.; WAN, W.G.; LE, H.Y.; et al. Continuous preparation of fructose syrups from Jerusalem artichoke tuber using immobilized intracellular inulinase from Kluyveromyces sp Y-85. Process Biochemistry, v. 34, n. 6/7, p. 643-646, 1999. 
WENLING, W.; HUTYING, W. W. L.; SHIYUAN, W. Continuous preparation of fructose syrups from Jerusalem artichoke tuber using immobilized intracellular inulinase from Kluyveromyces sp. Y-85. Process Biochemistry, v. 34, p. 643-646, 1999.

WISEMAN, A. Handbook of Enzyme Biotechnology 2. ed. Chichester, England: Ellis Horwood, 1985. 457p.

WORTHINGTON BIOCHEMICAL CORPORATION. Enzyme manual (Pectinase). www.worthington-biochem.com. (21 mai. 2001).

WU, F.; TSENG, R.; JUANG, R. Ehanced abilities if highly swollen chitosan beads for color removal and tyrosinase immobilization. Journal of hazardous Materials, v. B81, p. 167-177, 2001.

YUN, J.W. Fructooligosaccharides-Occurrence, preparation, and application. Enzyme and Microbial Technology, v. 19, p. 107-117, 1996.

YUN, J.W.; KIM, D.H.; KIM, B.W.; et al. Production of inulo-oligosaccharides from inulin by immobilized endoinulinase from Pseudomonas sp. Journal of Fermentation and Bioengineering, v. 84, n. 4, p. 369-371, 1997. 
APÊNDICES 
APÊNDICE 1: Ensaio realizado na imobilização nas diferentes matrizes no sistema descontínuo (batelada)

\begin{tabular}{|c|c|c|c|c|c|}
\hline & $\begin{array}{c}\text { Média } \\
\text { das D.O. }\end{array}$ & $\begin{array}{c}\text { Médias D.O. } \\
520 \mathrm{~nm}\end{array}$ & $\begin{array}{c}\text { Média } \\
520 \mathrm{~nm}\end{array}$ & & \\
$5220 \mathrm{~nm}$ & Média & $\begin{array}{c}\text { AR } \\
(\%)\end{array}$ \\
\hline & $\begin{array}{c}1^{\circ} \\
\text { ensaio }\end{array}$ & $\begin{array}{c}2^{\circ} \\
\text { ensaio }\end{array}$ & $\begin{array}{c}3^{\circ} \\
\text { ensaio }\end{array}$ & & \\
\hline Solução sacarose 10\% & 0,000 & 0,000 & 0,000 & 0,000 & - \\
\hline Quitina & 0,080 & 0,070 & 0,070 & 0,073 & 1,29 \\
\hline Sobrenadante restante quitina & 0,240 & 0,230 & 0,235 & 0,235 & 4,15 \\
\hline Alginato & 0,070 & 0,070 & 0,075 & 0,072 & 1,26 \\
\hline Sobrenadante restante alginato & 0,360 & 0,360 & 0,350 & 0,357 & 6,29 \\
\hline Nylon 6 & 0,050 & 0,050 & 0,050 & 0,050 & 0,88 \\
\hline Sobrenadante restante nylon 6 & 0,360 & 0,370 & 0,350 & 0,360 & 6,35 \\
\hline Poliestireno (isopor) & 0,025 & 0,020 & 0,015 & 0,020 & 0,35 \\
\hline Sobrenadante restante isopor & 0,380 & 0,380 & 0,380 & 0,380 & 6,71 \\
\hline Copolimero Alginato/Quitosana (A/Q) & 0,070 & 0,070 & 0,070 & 0,070 & 1,24 \\
\hline Sobrenadante restante (A/Q) & 0,300 & 0,280 & 0,280 & 0,287 & 5,06 \\
\hline Extrato enzimático original & 0,400 & 0,400 & 0,400 & 0,400 & 7,06 \\
\hline
\end{tabular}

Aproveitamento \% em relação ao extrato enzimático original

\begin{tabular}{|c|c|}
\hline Quitina & 18,33 \\
\hline Alginato & 17,92 \\
\hline Nylon 6 & 12,50 \\
\hline Poliestireno (isopor) & 5,00 \\
\hline Copolimero Algin./Quit. (A/Q) & 17,50 \\
\hline
\end{tabular}


APÊNDICE 2: Teste de atividade enzimática em diferentes $\mathrm{pHs}$ de tratamento na purificação por precipitação isoelétrica. Acúcares redutores formados com as fraçōes em diferente $\mathrm{pHs}$, determinação de proteínas totais por D. $^{\circ} 280 \mathrm{~nm}$ e pesagem do pellet formado na precipitação das proteínas

\begin{tabular}{|c|c|c|c|}
\hline Amostra $/ \mathrm{pH}$ & \% de açúcar & DO & Pellet \\
\hline & & Extrapol. & $\mathrm{mg}$ \\
\hline 7,03 & 6,288 & 0,7188 & 0 \\
\hline 6,82 & 5,590 & 0,6747 & 0 \\
\hline 6,43 & 5,415 & 0,6633 & 0 \\
\hline 6,31 & 5,852 & 0,6834 & 0 \\
\hline 6,11 & 5,546 & 0,6591 & 0 \\
\hline 5,51 & 6,550 & 0,6435 & 0,1 \\
\hline 5,29 & 6,201 & 0,6501 & 0,1 \\
\hline 5,02 & 6,681 & 0,6228 & 0,1 \\
\hline 4,5 & 5,764 & 0,6489 & 0,2 \\
\hline 4,4 & 7,293 & 0,6267 & 0,2 \\
\hline 4,31 & 5,633 & 0,6246 & 0,2 \\
\hline 4,21 & 6,681 & 0,633 & 0,3 \\
\hline
\end{tabular}

Sobrenadante $=7,03$

Gráfico da dosagem de proteina por D.O. e pellet formado.

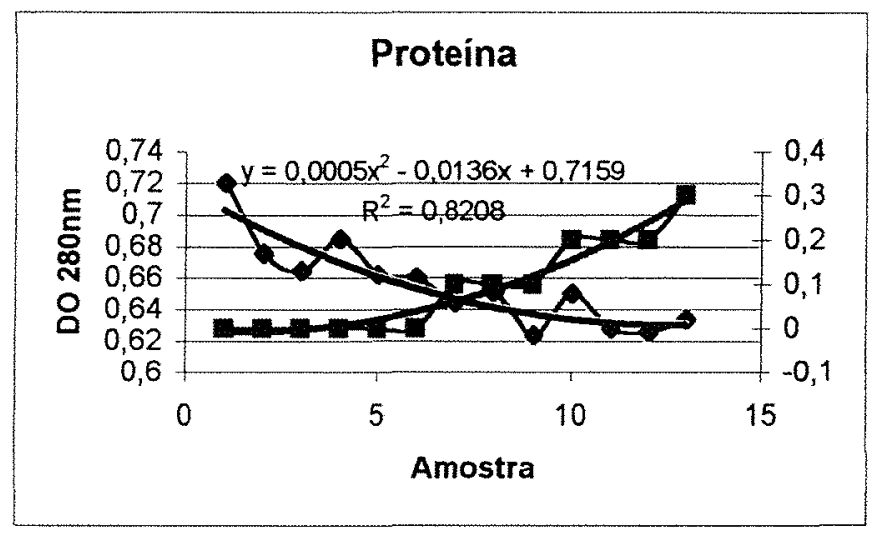


APÊNDICE 3: Fluxo contínuo em alginato quitosana dados de três experimentos e cálculos envolvidos

Atividade enzimática (AR formado (\%))

\begin{tabular}{|c|c|c|c|c|c|}
\hline Amostra & Tempo & to ensaio & 20 ensaio & 3o ensaio & Média \\
\hline & (h) & & & & \\
\hline 0 & 0 & 0,000 & 0,000 & 0,000 & 0,000 \\
\hline 1 & 1 & 0,104 & 0,219 & 0,111 & 0,145 \\
\hline 2 & 2 & 0,261 & 0,319 & 0,182 & 0,254 \\
\hline 3 & 3 & 0,243 & 0,248 & 0,157 & 0,216 \\
\hline 4 & 6 & 0,242 & 0,187 & 0,140 & 0,190 \\
\hline 5 & 9 & 0,166 & 0,326 & 0,137 & 0,210 \\
\hline 6 & 12 & 0,141 & 0,323 & 0,150 & 0,205 \\
\hline 7 & 15 & 0,139 & 0,283 & 0,184 & 0,202 \\
\hline 8 & 18 & 0,127 & 0,275 & 0,182 & 0,192 \\
\hline 9 & 21 & 0,144 & 0,282 & 0,150 & 0,192 \\
\hline
\end{tabular}

Atividade enzimática corrigida pela variação do fluxo.

\begin{tabular}{|c|c|c|c|c|c|}
\hline Amostra & $\begin{array}{c}\text { Tempo } \\
(\mathrm{h})\end{array}$ & 10 ensaio & 20 ensaio & 3o ensaio & Média \\
\hline 0 & 0 & 0,000 & 0,000 & 0,000 & 0,000 \\
\hline 1 & 1 & 0,778 & 1,7356 & 1,3088 & 1,274 \\
\hline 2 & 2 & 1,904 & 2,4897 & 2,1705 & 2,188 \\
\hline 3 & 3 & 1,735 & 1,7428 & 1,8469 & 1,775 \\
\hline 4 & 6 & 1,908 & 1,3541 & 1,6505 & 1,638 \\
\hline 5 & 9 & 1,218 & 2,5854 & 1,6531 & 1,819 \\
\hline 6 & 12 & 1,130 & 2,7865 & 1,7806 & 1,899 \\
\hline 7 & 15 & 1,256 & 2,6730 & 2,1668 & 2,032 \\
\hline 8 & 18 & 0,914122 & 2,5725 & 2,2790 & 1,922 \\
\hline 9 & 21 & 1,319834 & 2,6634 & 1,8315 & 1,938 \\
\hline
\end{tabular}

Proteina medida na saída

\begin{tabular}{|c|c|c|c|c|c|}
\hline Amostra & Tempo & 10 ensaio & 20 ensaio & 3o ensaio & Média \\
\hline & (h) & & & & \\
\hline 0 & 0 & 292,596 & 292,596 & 347,708 & 310,967 \\
\hline 1 & 1 & 51,095 & 80,1182 & 124,5353 & 85,249 \\
\hline 2 & 2 & 27,981 & 49,0094 & 132,7964 & 69,929 \\
\hline 3 & 3 & 20,681 & 33,3681 & 76,6212 & 43,557 \\
\hline 4 & 6 & 16,858 & 18,7696 & 45,6423 & 27,090 \\
\hline 5 & 9 & 13,556 & 18,7696 & 32,2181 & 21,514 \\
\hline 6 & 12 & 12,339 & 15,9889 & 19,0004 & 15,776 \\
\hline 7 & 15 & 11,296 & 11,1227 & 36,7617 & 19,727 \\
\hline 8 & 18 & 10,60132 & 12,6868 & 27,8810 & 17,056 \\
\hline 9 & 21 & 10,07994 & 11,9917 & 16,5221 & 12,865 \\
\hline
\end{tabular}


APÊNDICE 4: Resumo dos resultados de fluxo contínuo no copolímero alginato quitosana

\begin{tabular}{|c|c|c|c|c|}
\hline Amostra & Tempo & AR (\%) & Atividade & Proteína \\
\hline & $(\mathrm{h})$ & & por fluxo & $(\mu \mathrm{g} / \mathrm{mL})$ \\
\hline 0 & 0 & 0,000 & 0,000 & 310,967 \\
\hline 1 & 1 & 0,145 & 1,274 & 85,249 \\
\hline 2 & 2 & 0,254 & 2,188 & 69,929 \\
\hline 3 & 3 & 0,216 & 1,775 & 43,557 \\
\hline 4 & 6 & 0,190 & 1,638 & 27,090 \\
\hline 5 & 9 & 0,210 & 1,819 & 21,514 \\
\hline 6 & 12 & 0,205 & 1,899 & 15,776 \\
\hline 7 & 15 & 0,202 & 2,032 & 19,727 \\
\hline 8 & 18 & 0,192 & 1,922 & 17,056 \\
\hline 9 & 21 & 0,192 & 1,938 & 12,865 \\
\hline
\end{tabular}

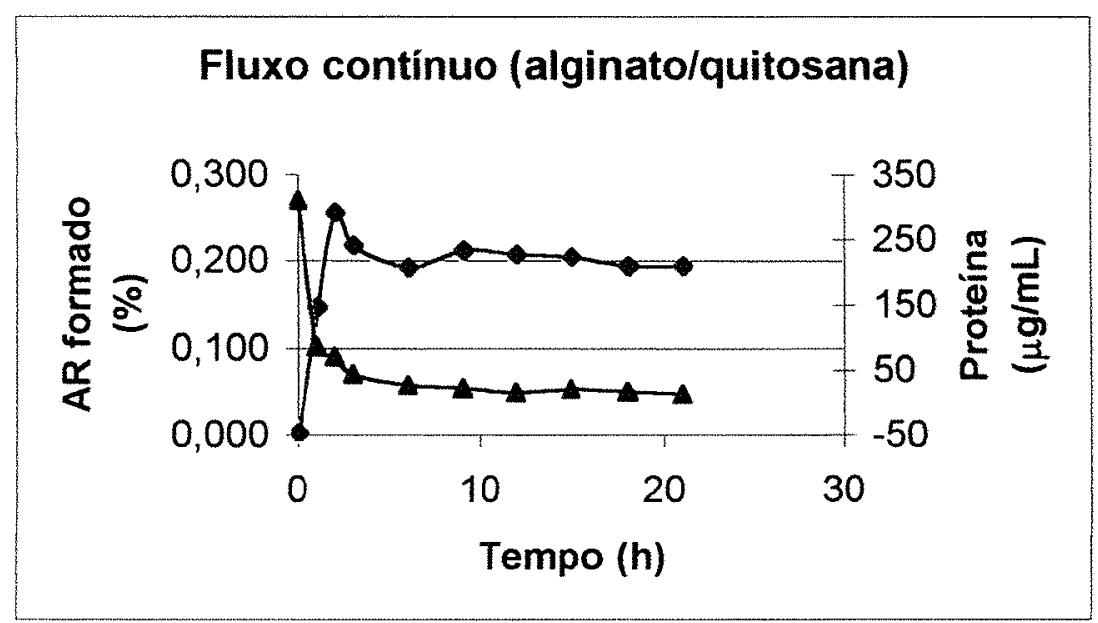


APÊNDICE 5: Ensaio de queda de atividade nas condições de conservação em freezer comum (temperatura próxima a $0^{\circ} \mathrm{C}$ )

Dados obtidos

\begin{tabular}{|c|c|c|}
\hline Dias & AR $\%$ & $\begin{array}{c}\% \\
\text { atividade }\end{array}$ \\
\hline 0,0 & 0,7 & 34,65347 \\
\hline 1,0 & 0,68 & 33,66337 \\
\hline 2,0 & 0,67 & 33,16832 \\
\hline 3,0 & 0,68 & 33,66337 \\
\hline 4,0 & 0,63 & 31,18812 \\
\hline 5,0 & 0,65 & 32,17822 \\
\hline 6,0 & 0,65 & 32,17822 \\
\hline 7,0 & 0,63 & 31,18812 \\
\hline 8,0 & 0,58 & 28,71287 \\
\hline 9,0 & 0,56 & 27,72277 \\
\hline 10,0 & 0,56 & 27,72277 \\
\hline 14,0 & 0,38 & 18,81188 \\
\hline
\end{tabular}

Gráfico de queda de atividade no decorrer dos dias

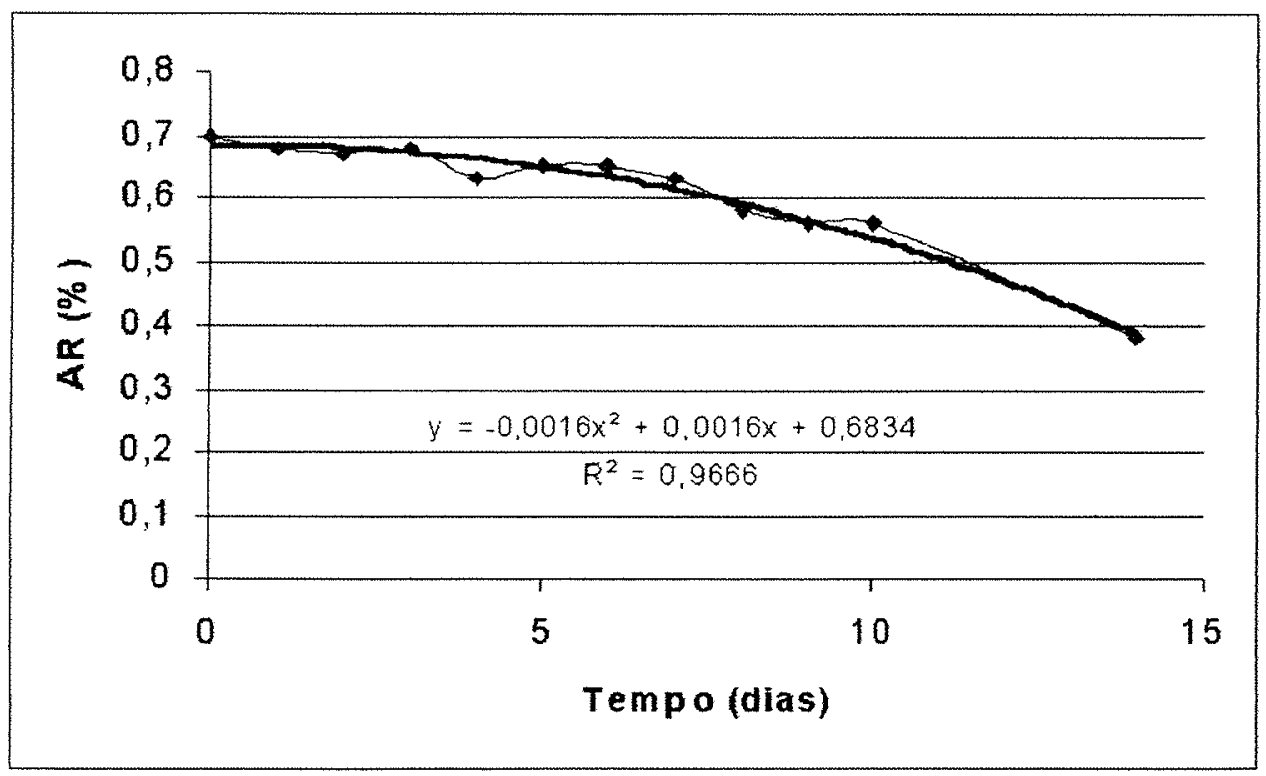


APÊNDICE 6: Ensaios no sistema descontínuo, realizados com o copolímero alginato-quitosana em cinco repetições. Neste ensaio se comparam as atividades no extrato bruto original, no extrato restante e no copolímero. A imobilização neste caso se deu por aprisionamento no copolímero dissolvendo-se alginato no extrato original

Açúcares redutores formados

\begin{tabular}{|c|c|c|c|c|c|c|}
\hline Amostra & $\begin{array}{c}\text { \% de açúcar } \\
\text { 10 ensaio }\end{array}$ & $\begin{array}{c}\text { \% de açúcar } \\
\text { 20 ensaio }\end{array}$ & $\begin{array}{c}\text { \% de açúcar } \\
\text { 30 ensaio }\end{array}$ & $\begin{array}{c}\% \text { de açúcar } \\
4^{\circ} \text { ensaio }\end{array}$ & $\begin{array}{c}\text { \% de açúcar } \\
50 \text { ensaio }\end{array}$ & $\begin{array}{c}\% \text { AR } \\
\text { média }\end{array}$ \\
\hline 0 & 0,000 & 0,000 & 0,000 & 0,000 & 0,000 & 0,000 \\
\hline Extrato Original & 2,00 & 1,96 & 1,64 & 1,82 & 1,50 & 1,78 \\
\hline Imobilizado A/Q & 1,08 & 1,06 & 0,97 & 0,91 & 0,82 & 0,97 \\
\hline Extrato restante & 0,72 & 0,62 & 0,71 & 0,62 & 0,59 & 0,65 \\
\hline Extrato Purificado & 0,65 & 0,59 & 0,60 & 0,73 & 0,54 & 0,62 \\
\hline Purif. Imobilizado A/Q & 1,06 & 0,93 & 0,91 & 0,75 & 0,75 & 0,88 \\
\hline Purificado restante & 0,12 & 0,13 & 0,20 & 0,18 & 0,16 & 0,16 \\
\hline
\end{tabular}

Análise de proteína nas frações

\begin{tabular}{|c|c|c|c|c|c|c|}
\hline Amostra & $\begin{array}{c}\text { Proteína } \\
10 \text { ensaio }\end{array}$ & $\begin{array}{c}\text { Proteína } \\
\text { 20 ensaio }\end{array}$ & $\begin{array}{c}\text { Proteína } \\
\text { 3o ensaio }\end{array}$ & $\begin{array}{c}\text { Proteina } \\
\text { 40 ensaio }\end{array}$ & $\begin{array}{c}\text { Proteina } \\
50 \text { ensaio }\end{array}$ & $\begin{array}{c}\text { Prot } \\
\text { média }\end{array}$ \\
\hline 0 & 0,000 & 0,000 & 0,000 & 0,000 & 0,000 & 0,000 \\
\hline Extrato Original & 242,36 & 224,38 & 224,38 & 250,42 & 236,16 & 235,54 \\
\hline Imobilizado A/Q desprendido & 73,14 & 66,12 & 63,43 & 62,29 & 61,57 & 65,31 \\
\hline Extrato restante & 64,46 & 58,47 & 59,30 & 63,35 & 63,64 & 61,84 \\
\hline Extrato Purificado & 166,12 & 151,24 & 176,65 & 183,05 & 176,03 & 170,62 \\
\hline Purif. Imobilizado A/Q desprendido & 74,38 & 53,93 & 57,23 & 59,32 & 68,39 & 62,65 \\
\hline Purificado restante & 51,65 & 57,64 & 65,08 & 61,23 & 64,26 & 59,97 \\
\hline
\end{tabular}

Média dos cinco ensaios.

\begin{tabular}{|c|c|c|c|c|}
\hline Amostra & $\begin{array}{c}\text { AR } \\
(\%)\end{array}$ & $\begin{array}{c}\text { Prot } \\
\mu \mathrm{g} / \mathrm{mL}\end{array}$ & $\begin{array}{c}\text { Atividade Relativa } \\
(\%)\end{array}$ & $\begin{array}{c}\text { Proteina relativa } \\
(\%)\end{array}$ \\
\hline 0 & 0,000 & 0 & & \\
\hline Extrato Original & 1,78 & 235,54 & 100 & 100 \\
\hline Imobilizado A/Q & 0,97 & 108,39 & 54,2 & 46,0 \\
\hline Extrato restante & 0,65 & 61,84 & 36,5 & 26,3 \\
\hline Extrato Purificado & 0,62 & 170,62 & 34,8 & 72,4 \\
\hline Purif. Imobilizado A/Q & 0,88 & 48,00 & 49,3 & 20,4 \\
\hline Purificado restante & 0,16 & 59,97 & 8,8 & 25,5 \\
\hline
\end{tabular}


APÊNDICE 7: Ensaios para a determinação de afinidade da enzima com sacarose (Km e Vmáx)

Tempo de 15 minutos

\begin{tabular}{|c|c|c|c|c|c|c|c|c|c|}
\hline Conc. & Vel 1 & Vel 2 & Vel 3 & Vel 4 & Vel 5 & Vel 6 & Vel 7 & Vel 8 & Média \\
\hline 0 & 0 & 0 & 0 & 0 & 0 & 0 & 0 & 0 & 0 \\
\hline 0,33 & 0,31 & 0,40 & 0,35 & 0,28 & 0,30 & 0,28 & 0,14 & 0,22 & 0,29 \\
\hline 0,67 & 0,56 & 0,56 & 0,74 & 0,65 & 0,55 & 0,49 & 0,44 & 0,45 & 0,55 \\
\hline 1,67 & 0,52 & 0,94 & 1,41 & 1,43 & 1,10 & 1,40 & - & - & 1,13 \\
\hline 3,33 & 0,61 & 0,85 & 1,78 & 2,28 & 1,80 & 1,68 & 0,71 & 0,64 & 1,08 \\
\hline 6,67 & - & - & - & 2,13 & 2,22 & 2,51 & 0,93 & 1,25 & 1,81 \\
\hline 13,33 & - & - & - & 2,61 & 2,72 & 2,66 & 2,33 & 1,43 & 2,35 \\
\hline 20,00 & - & - & - & - & - & 2,95 & 2,66 & 2,44 & 2,68 \\
\hline
\end{tabular}

Tempo de 30 minutos

\begin{tabular}{|c|c|c|c|c|c|c|c|c|c|}
\hline Conc. & Vel 1 & Vel 2 & Vel 3 & Vel 4 & Vel 5 & Vel 6 & Vel 7 & Vel 8 & Média \\
\hline 0 & 0 & 0 & 0 & 0 & 0 & 0 & 0 & 0 & 0 \\
\hline 0,33 & 0,40 & 0,44 & 0,35 & 0,30 & 0,31 & 0,32 & 0,14 & 0,21 & 0,31 \\
\hline 0,67 & 0,60 & 0,78 & 0,71 & 0,65 & 0,56 & 0,50 & 0,50 & 0,51 & 0,60 \\
\hline 1,67 & 0,98 & 1,40 & 1,93 & 1,55 & 1,40 & 1,54 & - & - & 1,47 \\
\hline 3,33 & 0,86 & 2,16 & 2,98 & 3,01 & 2,70 & 2,31 & 1,31 & 1,20 & 2,00 \\
\hline 6,67 & - & - & - & 3,12 & 4,51 & 3,94 & 1,87 & 2,23 & 3,13 \\
\hline 13,33 & - & - & - & 3,50 & 4,78 & 5,19 & 3,73 & 2,10 & 3,86 \\
\hline 20,00 & - & - & - & - & - & 3,37 & 4,51 & 4,81 & 4,23 \\
\hline
\end{tabular}

Tempo de 45 minutos

\begin{tabular}{|c|c|c|c|c|c|c|c|c|c|}
\hline Conc. & Vel 1 & Vel 2 & Vel 3 & Vel 4 & Vel 5 & Vel 6 & Vel 7 & Vel 8 & Média \\
\hline 0 & 0 & 0 & 0 & 0 & 0 & 0 & 0 & 0 & 0 \\
\hline 0,33 & 0,39 & 0,45 & 0,37 & 0,34 & 0,32 & 0,29 & 0,17 & 0,24 & 0,32 \\
\hline 0,67 & 0,60 & 0,79 & 0,69 & 0,68 & 0,58 & 0,53 & 0,55 & 0,49 & 0,61 \\
\hline 1,67 & 1,49 & 2,28 & 1,98 & 1,56 & 1,41 & 1,47 & - & - & 1,70 \\
\hline 3,33 & 1,41 & 3,22 & 3,71 & 3,03 & 2,65 & 2,76 & 1,92 & 1,82 & 2,78 \\
\hline 6,67 & - & - & - & 0,00 & 7,15 & 5,47 & 2,74 & 2,91 & 3,65 \\
\hline 13,33 & - & - & - & 0,00 & 7,40 & 6,83 & 5,25 & 3,47 & 4,59 \\
\hline 20,00 & - & - & - & - & - & 7,38 & 5,97 & 6,91 & 6,75 \\
\hline
\end{tabular}


APÊNDICE 8: Ensaios para a determinação de afinidade da enzima com inulina (Km e Vmáx)

Tempo de 15 minutos

\begin{tabular}{|c|c|c|c|c|c|c|c|c|}
\hline Conc. & Vel 1 Vel 2 & Vel 3 & Vel 4 & Vel 5 & Vel 6 & Vel 7 & Média \\
\hline 0 & 0 & 0 & 0 & 0 & 0 & 0 & 0 & 0 \\
\hline 0,33 & 0,02 & 0,00 & 0,06 & 0,05 & 0,03 & 0,02 & 0,02 & 0,03 \\
\hline 0,67 & 0,04 & 0,06 & 0,10 & 0,07 & 0,06 & 0,03 & 0,04 & 0,06 \\
\hline 1,67 & 0,07 & 0,08 & 0,17 & 0,12 & - & - & - & 0,11 \\
\hline 3,33 & 0,09 & 0,15 & 0,23 & 0,20 & 0,19 & 0,16 & 0,05 & 0,15 \\
\hline 6,67 & - & - & - & 0,38 & 0,31 & 0,25 & 0,13 & 0,27 \\
\hline 13,33 & - & - & - & 0,60 & 0,41 & 0,31 & 0,24 & 0,39 \\
\hline 20,00 & - & - & - & - & 0,53 & 0,33 & 0,35 & 0,40 \\
\hline
\end{tabular}

Tempo de 30 minutos

\begin{tabular}{|c|c|c|c|c|c|c|c|c|}
\hline Conc. & Vel 1 & Vel 2 & Vel 3 & Vel 4 & Vel 5 & Vel 6 & Vel 7 & Média \\
\hline 0 & 0 & 0 & 0 & 0 & 0 & 0 & 0 & 0 \\
\hline 0,33 & 0,05 & 0,06 & 0,10 & 0,09 & 0,06 & 0,08 & 0,03 & 0,07 \\
\hline 0,67 & 0,07 & 0,10 & 0,15 & 0,15 & 0,09 & 0,10 & 0,06 & 0,10 \\
\hline 1,67 & 0,11 & 0,16 & 0,28 & 0,23 & - & - & - & 0,19 \\
\hline 3,33 & 0,15 & 0,26 & 0,40 & 0,38 & 0,31 & 0,27 & 0,13 & 0,27 \\
\hline 6,67 & - & - & - & 0,64 & 0,49 & 0,42 & 0,25 & 0,45 \\
\hline 13,33 & - & - & - & 1,12 & 0,68 & 0,51 & 0,50 & 0,70 \\
\hline 20,00 & - & - & - & - & 0,86 & 0,65 & 0,67 & 0,72 \\
\hline
\end{tabular}

Tempo de $45 \mathrm{~min}$

\begin{tabular}{|c|c|c|c|c|c|c|c|c|}
\hline Conc. & Vel 1 & Vel 2 & Vel 3 & Vel 4 & Vel 5 & Vel 6 & Vel 7 & Média \\
\hline 0 & 0 & 0 & 0 & 0 & 0 & 0 & 0 & 0 \\
\hline 0,33 & 0,07 & 0,00 & 0,06 & 0,12 & 0,08 & 0,09 & 0,05 & 0,07 \\
\hline 0,67 & 0,10 & 0,06 & 0,10 & 0,18 & 0,12 & 0,14 & 0,09 & 0,11 \\
\hline 1,67 & 0,13 & 0,08 & 0,17 & 0,31 & - & - & - & 0,17 \\
\hline 3,33 & 0,18 & 0,15 & 0,23 & 0,53 & 0,41 & 0,37 & 0,16 & 0,29 \\
\hline 6,67 & - & - & - & 0,89 & 0,64 & 0,57 & 0,32 & 0,60 \\
\hline 13,33 & - & - & - & 1,35 & 0,94 & 0,65 & 0,55 & 0,87 \\
\hline 20,00 & - & - & - & - & 1,13 & 0,80 & 0,66 & 0,87 \\
\hline
\end{tabular}




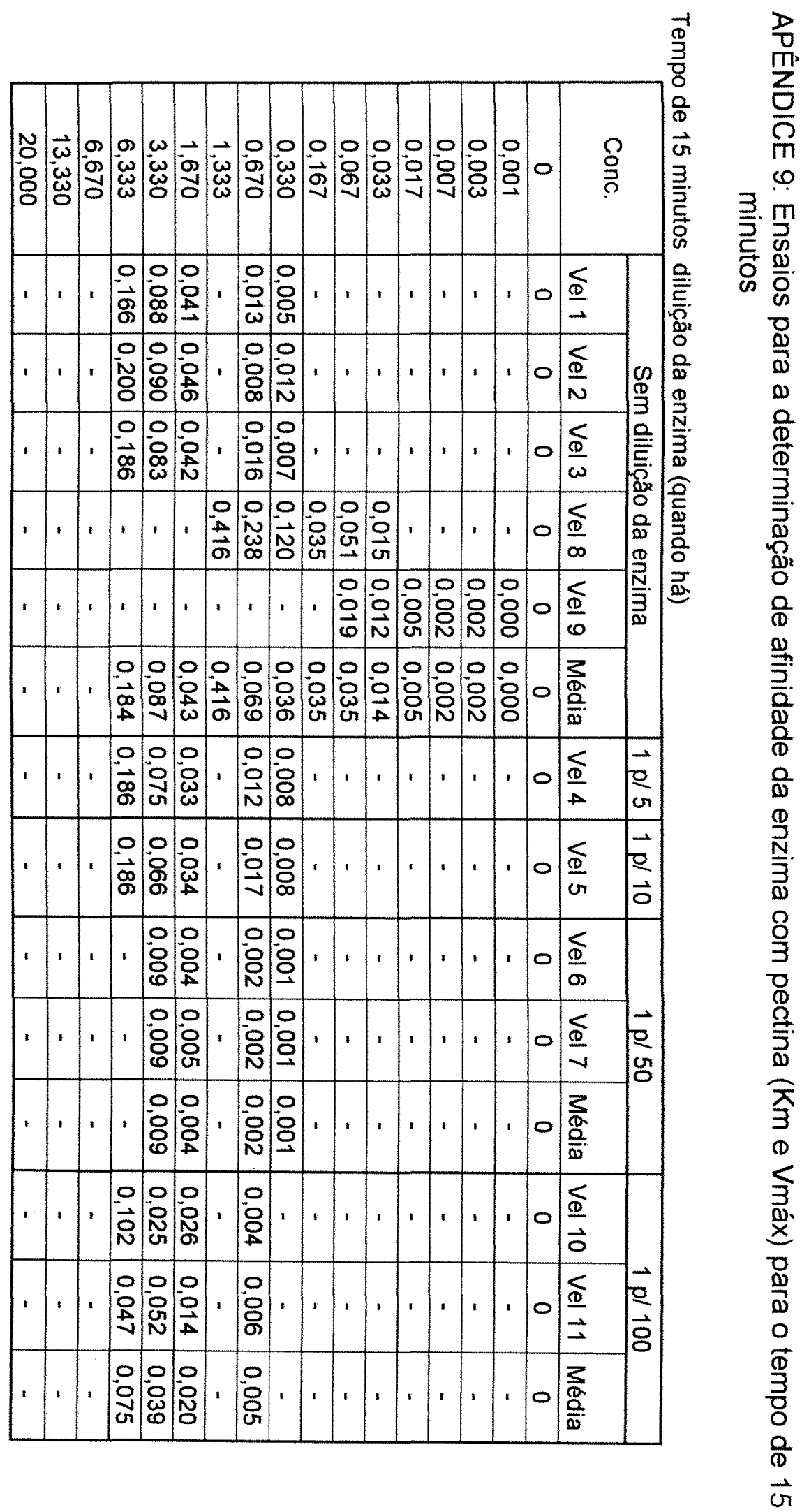




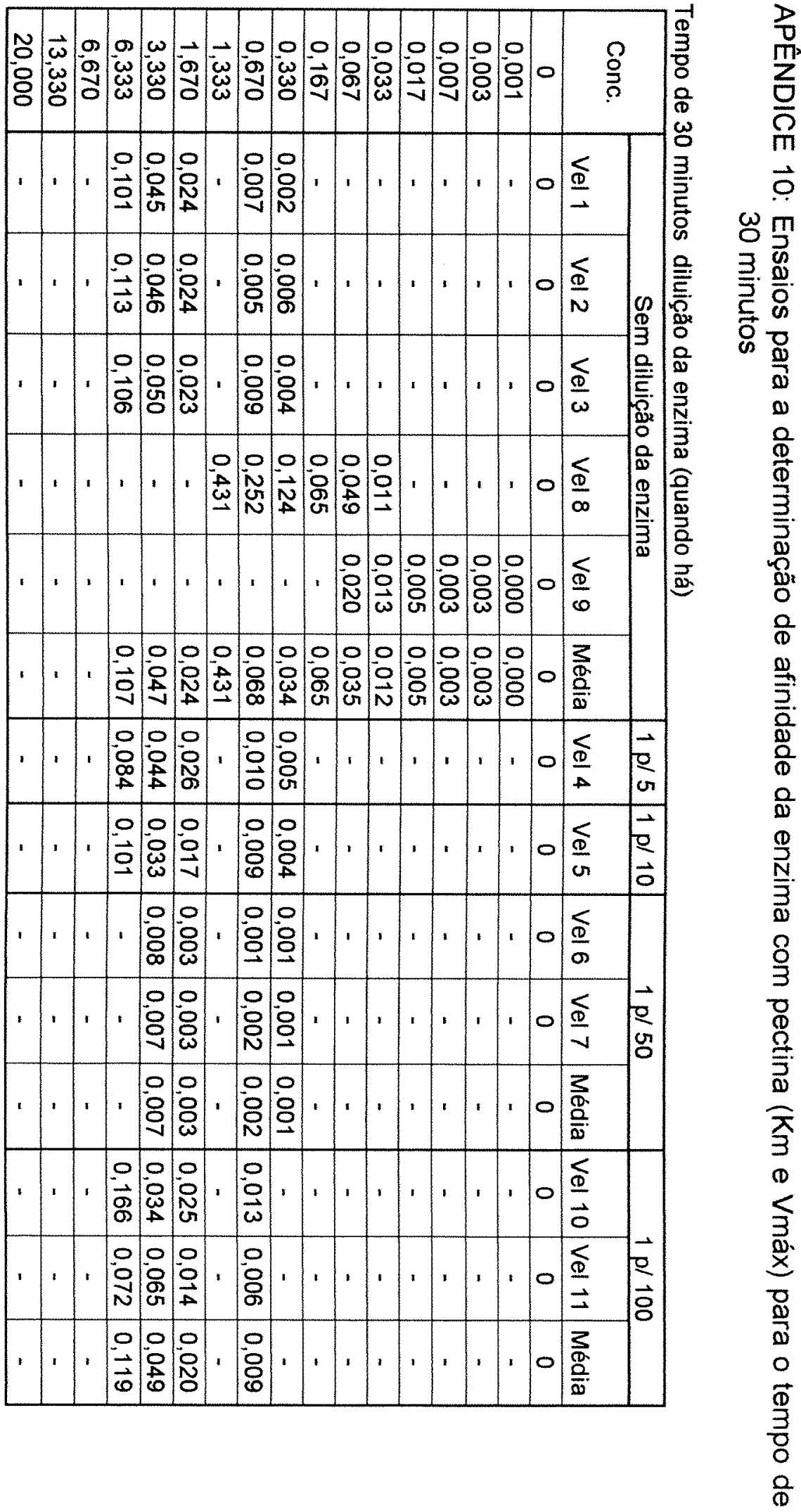




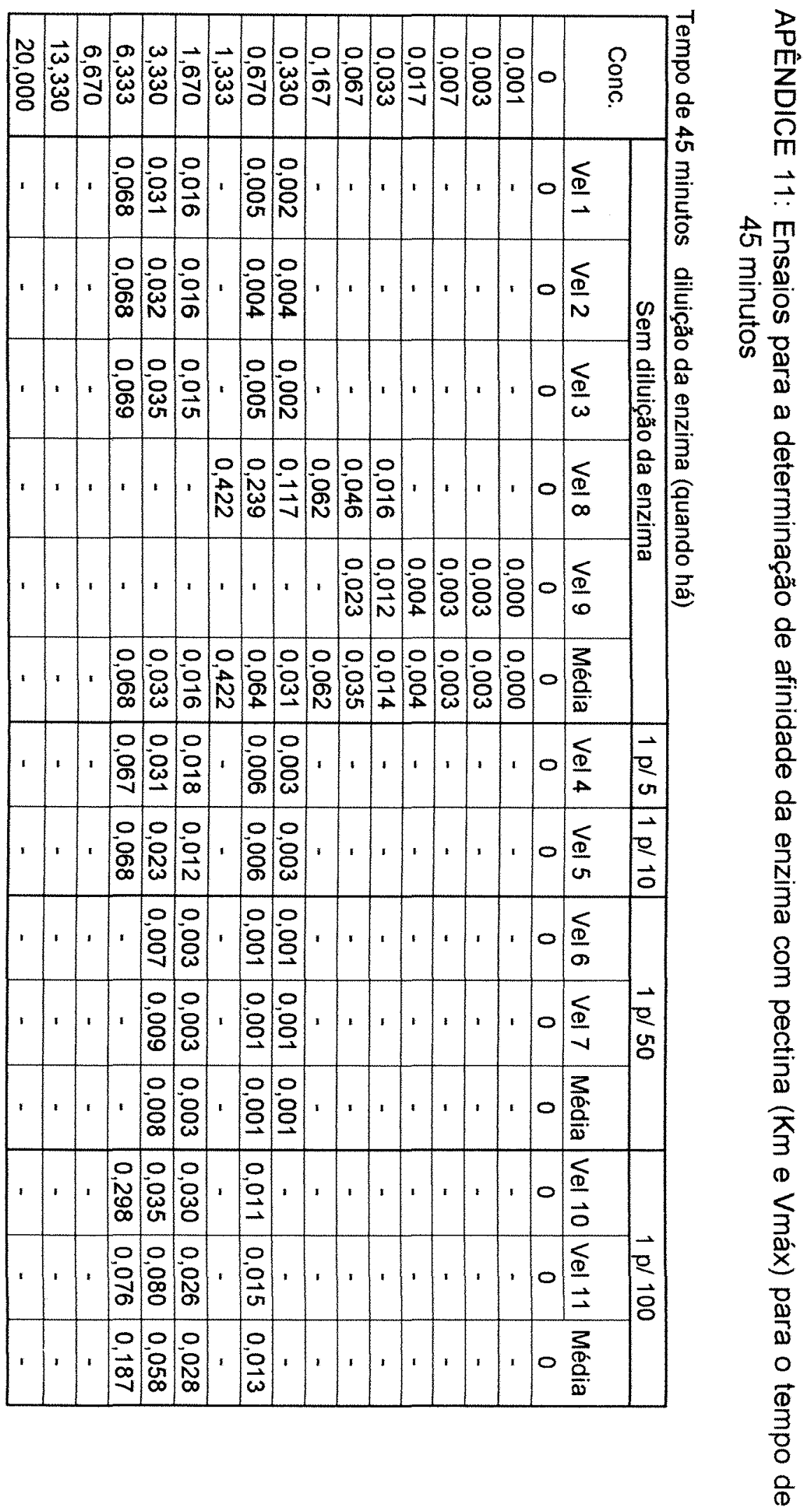



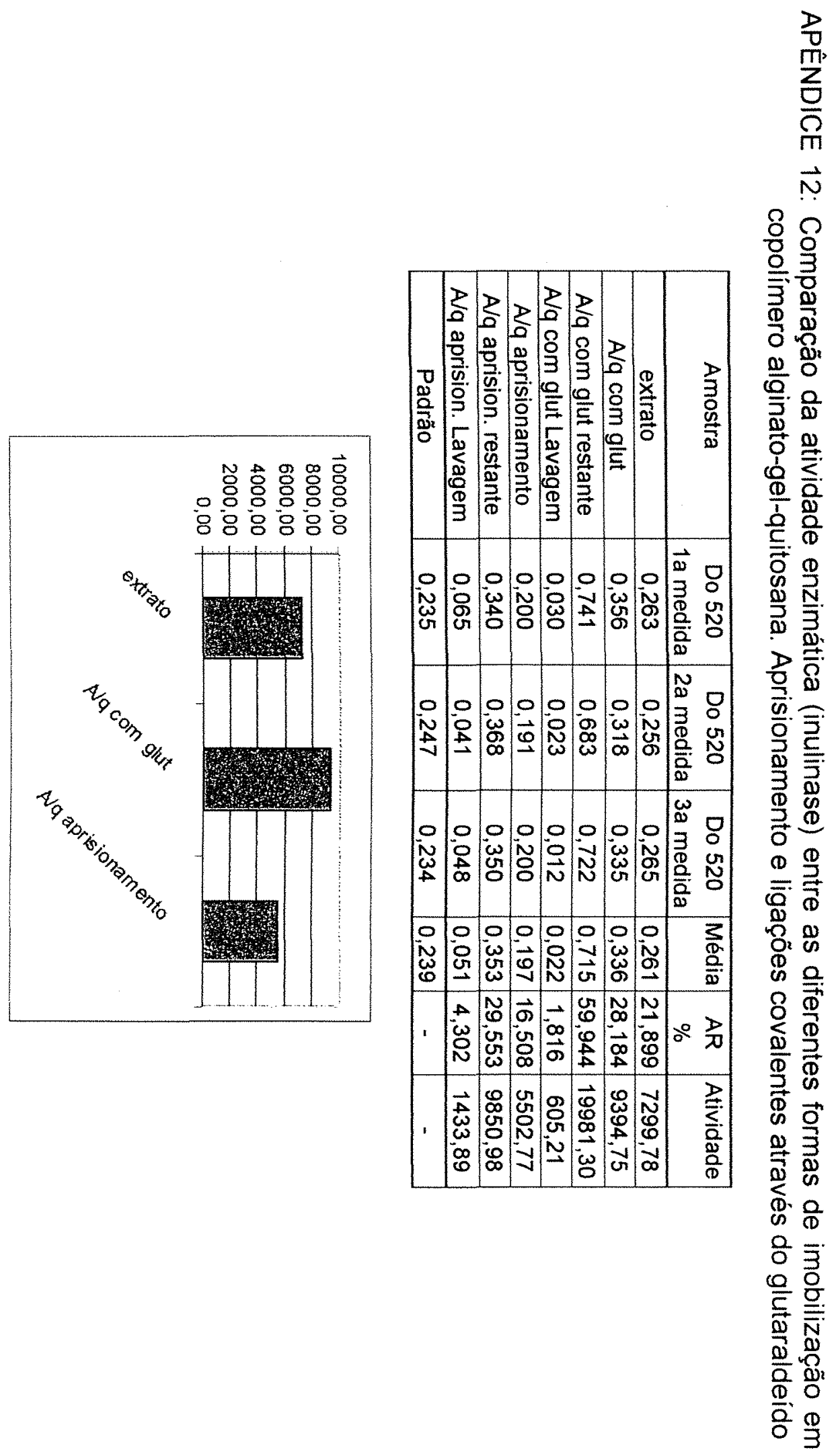